Review

\title{
Complex Catalytic Materials Based on the Perovskite-Type Structure for Energy and Environmental Applications
}

\author{
Florin Andrei 1,2, Rodica Zăvoianu 1,3,*(D) and Ioan-Cezar Marcu 1,3,*(D) \\ 1 Laboratory of Chemical Technology \& Catalysis, Department of Organic Chemistry, \\ Biochemistry \& Catalysis, Faculty of Chemistry, University of Bucharest, 4-12, \\ Blv. Regina Elisabeta, 030018 Bucharest, Romania; florin.andrei@inflpr.ro \\ 2 Interdisciplinary Innovation Center of Photonics and Plasma for Eco-Nano Technologies \\ and Advanced Materials, National Institute for Laser, Plasma and Radiation Physics, \\ 409 Atomistilor Street, 077125 Magurele, Romania \\ 3 Research Center for Catalysts and Catalytic Processes, Faculty of Chemistry, \\ University of Bucharest, 4-12 Blv Regina Elisabeta, 030018 Bucharest, Romania \\ * Correspondence: rodica.zavoianu@chimie.unibuc.ro (R.Z.); \\ ioancezar.marcu@chimie.unibuc.ro (I.-C.M.); Tel.: +40-21-3051464 (I-C.M.)
}

Received: 12 November 2020; Accepted: 3 December 2020; Published: 5 December 2020

check for updates

\begin{abstract}
This review paper focuses on perovskite-type materials as (photo)catalysts for energy and environmental applications. After a short introduction and the description of the structure of inorganic and hybrid organic-inorganic perovskites, the methods of preparation of inorganic perovskites both as powders via chemical routes and as thin films via laser-based techniques are tackled with, for the first, an analysis of the influence of the preparation method on the specific surface area of the material obtained. Then, the (photo)catalytic applications of the perovskites in energy production either in the form of hydrogen via water photodecomposition or by methane combustion, and in the removal of organic pollutants from waste waters, are reviewed.
\end{abstract}

Keywords: perovskite; catalyst; water photodecomposition; methane combustion; pollutant photodegradation

\section{Introduction}

The 21st century has brought new challenges to scientists in solving the issues generated, on the one hand, by the increased demand for energy and, on the other hand, by the more stringent exigencies in environmental protection. In recent years we witnessed a continuous search to find more economically viable processes to generate cleaner energy starting from well known as well as from new renewable resources using more performant catalysts than conventional ones. In this respect, researchers have been focused on developing new catalysts and to perfect the existing ones in order to enhance the sustainability of energy-generating processes. An example illustrating the development of the research trends concerns the utilization of perovskite-type materials as catalysts for different processes involving energy production as well as removal of pollutants by oxidation processes. Complex oxides having an $\mathrm{ABO}_{3}$ perovskite-type structure are possible candidates for catalytic combustion, their potential as oxidation catalysts being studied for the first time approximately 50 years ago [1,2]. These oxide materials are very active, highly thermally stable and present low volatility. Due to these properties, they were considered as potential candidates to replace the expensive oxide-supported noble metals (especially platinum and palladium) which are currently the combustion catalysts used on a large scale. 
The utilization of perovskite-type materials for this aim allows surpassing the issues posed by the formation of noble metals volatile oxides or by their sintering at high temperatures [3-5].

Photocatalysis is considered the key of solving energy generation and environmental pollution problems since it can use sunlight, which is one of the cleanest energy sources. Perovskites are intensively studied as photocatalysts, for several reactions such as: generation of hydrogen by photodecomposition of water and total photo-oxidation of different organic pollutants [6,7].

The purpose of this literature review is to highlight the state of the art concerning the influence of the physico-chemical properties of perovskite-type materials on their catalytic and photocatalytic efficiencies, focusing mainly on photoelectrochemical water splitting, the photodecomposition of organic pollutants and the catalytic combustion of methane reactions. To this aim, the scientific information from more than 300 references published during the last 20 years has been screened.

\section{General Aspects Concerning Perovskites Materials}

\subsection{Inorganic Perovskites}

Most of the chemical compounds having the general formula $\mathrm{ABO}_{3}$ with $\mathrm{r}\left(\mathrm{A}^{\mathrm{n}+}\right) \approx 2 \mathrm{r}\left(\mathrm{B}^{\mathrm{m}+}\right)$ (where $\mathrm{r}$ is the ionic radius of $\mathrm{A}$ and $\mathrm{B}$ cations with different valences forming compounds such as: $\mathrm{A}^{\mathrm{I}} \mathrm{B}^{\mathrm{V}} \mathrm{O}_{3}$, $\mathrm{A}^{\mathrm{II}} \mathrm{B}^{\mathrm{IV}} \mathrm{O}_{3}$ and $\mathrm{A}^{\mathrm{III}} \mathrm{B}^{\mathrm{III}} \mathrm{O}_{3}$ ) show an inorganic perovskite-type structure. Perovskites' name derives from the first found mineral $\mathrm{CaTiO}_{3}$ which has the same atomic arrangement [8]. The unit cell of $\mathrm{CaTiO}_{3}$ is represented as a cube, where the corners are occupied by calcium ions, the titanium ions are positioned at the body's center, and oxygen ions at the faces center (Figure 1). The name and the simple cubic structure were preserved even though in 1946 Megaw determined that $\mathrm{CaTiO}_{3}$ has an orthorhombic structure [9]. In the perovskite structure, the larger cation A is 12-fold coordinated with oxygen ions and responsible for the stability properties, having minor effects on the catalytic properties. Generally, the cations $\mathrm{A}$ are elements with inert $\mathrm{d}^{0}$ and $\mathrm{f}^{0}$ electronic structure, such as alkaline or rare earth cations. The catalytic activity is influenced by the smaller B cations with an octahedral coordination, which are usually $3 \mathrm{~d}, 4 \mathrm{~d}$ or $5 \mathrm{~d}$ transition metals acting as active sites, because they have the ability to perform redox cycles without structure destruction $[8,10]$.

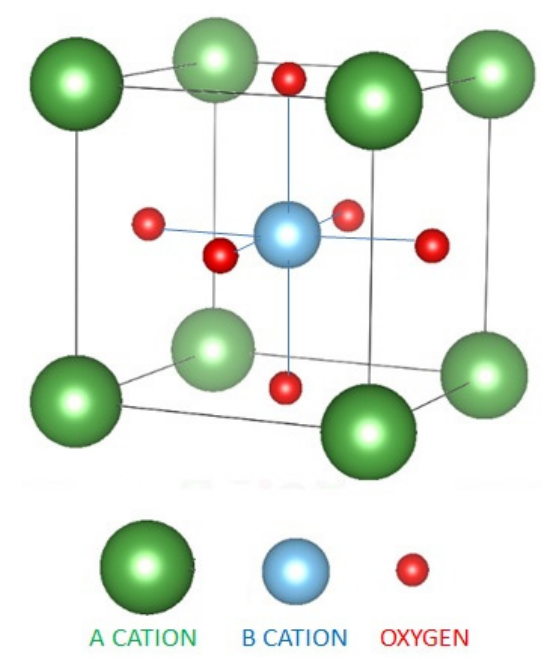

Figure 1. Inorganic $\mathrm{ABO}_{3}$ perovksite structure.

In 1926, Goldschmidt [11] has defined a tolerance factor:

$$
t=\left(r_{A}+r_{O}\right) / 2^{1 / 2}\left(r_{B}+r_{O}\right)
$$

where $r_{A}, r_{B}$ and $r_{O}$ are the ionic radii of $A$ and $B$ cations and $O$ anions, respectively, which is correlated to the thermodynamic and structural stability. The ideal perovskite cubic structure is stable 
only if $0.8<\mathrm{t}<0.9$, this range being slightly larger in the case of distorted perovskite structures. At room temperature, a distortion in the structure may exist, but at high temperatures, the cubic structure is formed. Besides the ideal cubic structure, other well-known symmetries for perovskites are: orthorhombic, rhombohedral, monoclinic and triclinic [12]. In catalysis, the perovskite stability during the catalytic cycles is an essential factor and it depends on the stability of the structural lattice, the valence stability of the transition metals in the reaction environment and, last but not least, the capability of defects' formation [8]. Perovskites have the ability to incorporate mixed valance cations in their structure by either isostructural substitution of cations in a mother structure or by formation of structural anion vacancies, affecting in this way the structural and catalytic properties [8]. The most used substitutions involve the replacing of half of $\mathrm{B}$ cations with other cations having different charge $\left(\mathrm{AB}^{\mathrm{x}+}{ }_{0.5} \mathrm{~B}^{\mathrm{y}+}{ }_{0.5} \mathrm{O}_{3}\right)$. This type of replacement determines a shift of the oxygen ions present in the ordered structure toward the cations with higher valence. Moreover, the A and B cations in perovskites can both be easily substituted leading to doped compounds with the formula $\mathrm{A}_{1-\mathrm{x}} \mathrm{A}_{\mathrm{x}}^{\prime} \mathrm{B}_{1-\mathrm{y}} \mathrm{B}_{\mathrm{y}}^{\prime} \mathrm{O}_{3}$ [12]. Perovskite materials also show excellent properties for several applications, such as: dielectric, piezoelectric, semiconductors, electro-optic or superconductors [13]. Their utilisation as catalysts for energy production and environmental protection is detailed in Section 5 of this review.

\subsection{Hybrid Organic-Inorganic Perowskites}

Hybrid organic-inorganic perovskites, denoted HOIPs, are a class of materials derived from inorganic perovskites with general formula $\mathrm{ABX}_{3}$. Compared to the pure inorganic perovskite, in HOIPs the $\mathrm{A}$ site and/or $\mathrm{X}$ site are substituted by cations of organic amines and different inorganic/organic anions $X$, respectively. In this way, the rigidity and the compactness of the perovskite structure are diminished, and the organic part offers more functionalities and enhanced flexibility [14-16]. Several examples of $\mathrm{A}$ and $\mathrm{X}$ organic ions that can be integrated in a hybrid organic-inorganic perovskite structure are presented in Figure 2. 


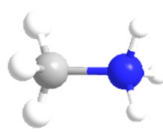

Methylammonium (MA) $\mathrm{CH}_{3} \mathrm{NH}_{3}{ }^{+}$

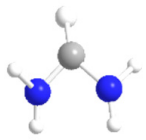

Formamidinium (FA) $\left(\mathrm{NH}_{2}\right)_{2} \mathrm{CH}^{+}$

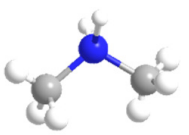

Dimethylammonium (DMA) $\left(\mathrm{CH}_{3}\right)_{2} \mathrm{NH}_{2}{ }^{+}$

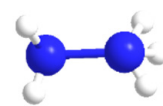

Hydrazonium (HAZ) $\mathrm{NH}_{2} \mathrm{NH}_{3}{ }^{+}$
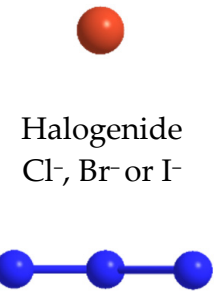

Azide

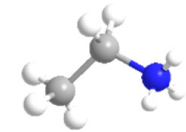

Ethylammonium (EA) $\mathrm{CH}_{3} \mathrm{CH}_{2} \mathrm{NH}_{3}{ }^{+}$

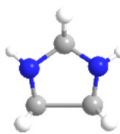

Imidazolium (HIM) $\mathrm{C}_{3} \mathrm{~N}_{2} \mathrm{H}_{5}{ }^{+}$

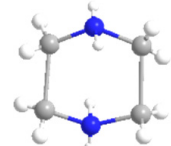

Piperazinium (PIP)

$\mathrm{C}_{4} \mathrm{H}_{12} \mathrm{~N}_{2}{ }^{2+}$

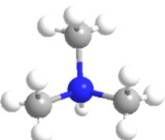

Trimethylammonium (TrMA)

$\left(\mathrm{CH}_{3}\right)_{3} \mathrm{NH}^{+}$

X-site

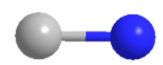

Cyanide

$\mathrm{CN}^{-}$

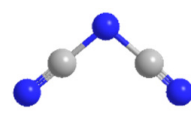

Dicyanamide $\mathrm{N}(\mathrm{CN})_{2}$

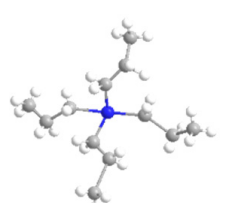

Tetrapropylammonium (TPrA) $\mathrm{N}\left(\mathrm{C}_{3} \mathrm{H}_{7}\right)_{4}^{+}$

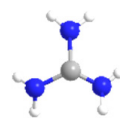

Guanidinium (GUA) $\mathrm{C}\left(\mathrm{NH}_{2}\right)_{3}{ }^{+}$

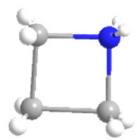

Azetidinium (AZE) $\left(\mathrm{CH}_{2}\right)_{3} \mathrm{NH}_{2}{ }^{+}$

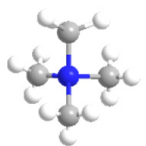

Tetramethylammonium (TMA)

$\left(\mathrm{CH}_{3}\right)_{4} \mathrm{~N}^{+}$

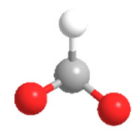

Formate $\mathrm{HCOO}^{-}$

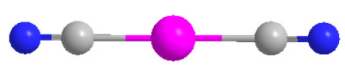

Dicyanometallate $\mathrm{M}(\mathrm{CN})^{-}$

Figure 2. A-site and X-site ions of hybrid organic-inorganic perovskites. Adapted from reference [15].

In 1978, the German researcher Dieter Weber reported for the first time the cubic phase of a hybrid perovskite (MA) $\mathrm{PbX}{ }_{3}$, where $\mathrm{MA}$ is metylammonium and $\mathrm{X}$ is a halogen anion $\left(\mathrm{Cl}^{-}, \mathrm{Br}^{-}\right.$or I- $\mathrm{I}^{-}$[16]. This structure shows an octahedral coordination around $\mathrm{Pb}^{2+}$ cations with halogen anions at the center of the faces of the cube, and the metylammonium cations occupy the A sites at the cube corners. Similar to the inorganic perovskites, the structure of HOIPs is defined by a Goldschmidt tolerance factor ( $\mathrm{t}$ ). The replacement of $\mathrm{A}$ and $\mathrm{X}$ sites in HOIPs with organic linkers leads to an adaption of this factor generating a formula with higher complexity, as follows:

$$
t=\left(r_{\text {Aeff }}+r_{\text {Xeff }}\right) / 2^{1 / 2}\left(r_{B}+h_{\text {Xeff }} / 2\right)
$$


where $r_{B}$ is the ionic radius of $B$ cation, $r_{A \text { eff }}$ is the effective radius of $A$ cation and $r_{\text {Xeff }}, h_{\text {Xeff }}$ are the effective radius and the height of $X$ anion modeled as a rigid cylinder, respectively. Many HOIPs show a tolerance factor ranging in the interval $0.8<\mathrm{t}<1$ [17].

The HOIPs are greatly utilized with excellent results for energy production as photovoltaics, while their efficiencies in catalytic applications are very low due to their instability. Considering the highlight of this scientific work and taking into account their instability in the reaction environment, this review will be focused only on inorganic perovskite materials.

\section{Preparation of Inorganic Perovskite Materials}

\subsection{Preparation of Powders via Chemical Routes}

\subsubsection{Co-Precipitation Method}

One of the simplest and utilized synthesis methods for perovskite catalysts is co-precipitation. This method implies the precipitation of the metal precursors (oxides, alkoxides, nitrates or other inorganic salts), when the solubility limit decreases as an effect of adding a chemical reagent. Nitric acid can be used for dissolving the metal precursors having a low solubility $[18,19]$, while an ammonium hydroxide solution can be used to adjust the $\mathrm{pH}$ in order to facilitate the precipitation [18-20]. The precipitate obtained is further aged, filtered and washed with deionized water until the salts in excess are completely eliminated. Finally, the resulting precipitate cake is dried, calcined and activated [21]. In order to obtain homogeneous products, it is necessary to precisely control some parameters, such as temperature, $\mathrm{pH}$, coprecipitation rate and the concentrations of precursors. The main advantage of using this preparation method is that the resulting materials present higher specific surface area (SSA) than those prepared by other methods [22,23].

\subsubsection{Synthesis from Amorphous Precursors-“Citrate” Method}

The "Citrate" method is a preparation technique which offers an extremely good control of the stoichiometry of reaction components. Moreover, it shows high reproducibility and an enhanced degree of homogeneity of the reaction mixture [24,25]. The principle of this method is based on a complexation reaction between metal cations (which were previously added in solution by dissolving specific metal nitrates in deionized water) and a chelating agent (generally citric acid, or ethylene glycol). The molar ratio between metal ions and complexing agent is 1:1 [26-28]. Other substances that can be used as chelating agents are: ethylenediaminetetraacetic acid (EDTA) [29], oxalic acid [30], tartaric acid [31] or glucose [32]. The resulting mixture is heated at $80-90^{\circ} \mathrm{C}$ leading to a very viscous solution. The complex formed between metal cations and organic ligand is finally calcined to obtain the mixed oxide $[26,27,31]$.

\subsubsection{Combustion Synthesis Method}

In this method, stoichiometric amounts of metal nitrates of the desired cations are brought in aqueous medium together with urea (or glycine, citric acid, glucose), which is used as sacrificial fuel. Nitrate salts are used not only for the strong oxidizing character of $\mathrm{NO}_{3}{ }^{-}$anions, but also for their high solubility in water. Urea is the most used organic fuel especially due to its low price [33,34]. Biamino and Badini have demonstrated on $\mathrm{LaCrO}_{3}$ that this process can be divided in two steps [35]. The first step is, in fact, the synthesis of the perovskite, which is an endothermic reaction, while the second step is the exothermic reaction between oxygen from nitrates and urea. Since the endothermic reaction, implying the transformation of nitrates into the desired oxides, requires a high amount of energy to be completed, the necessary energy is provided by the oxidation of urea. Finally, a stabilization treatment is applied and the catalysts are calcined for $4 \mathrm{~h}$ in air in order to remove all carbonaceous deposits [36]. This method can be used to form perovskite oxides having a nanometric particle size. 


\subsubsection{Hydrothermal Synthesis}

When applying this method, the metallic precursors are dissolved in water or are brought in the form of a slurry under high pressure and temperature conditions. An important advantage of this technique is that crystalline powders can be obtained without calcination. The particle size and shape can be modified by controlling the reaction temperature, $\mathrm{pH}$ and the reagent's concentration [37-39].

\subsubsection{Solid State Reactions}

By this method, the metallic precursors (generally nitrates, carbonates or oxides) can be mixed with enhanced accuracy of the stoichiometric ratios of cations. Practically, the reagents are ball milled in a milling container. The resulting material is dried at $100^{\circ} \mathrm{C}$ and calcined at $600{ }^{\circ} \mathrm{C}$ for $4-8 \mathrm{~h}$ in air. Afterward, the product is ground and sieved in order to collect solid particles with similar sizes and further calcined for longer time $(5-15 \mathrm{~h})$ at higher temperature $\left(1300-1600^{\circ} \mathrm{C}\right)$. The final product is again ground and sieved to collect the granular fraction having the appropriate size for its further utilisation [40-42].

\subsubsection{Influence of the Preparation Method on the Specific Surface Area of the Perovskite-Type Materials}

It is well known that the specific surface area (SSA) plays a crucial role in the catalytic processes. Depending on the preparation method of the catalysts, the porosity, size and shape of pores and the pore distribution are significantly different. An optimization of previously mentioned structural parameters can lead to the design of highly active catalysts [43]. Next, different classes of materials based on perovskite-type structure are presented taking into account their textural characteristics and their ability to be an efficient candidate for catalytic reactions.

The influence of the preparation method on the specific surface area of undoped and doped $\mathrm{ABO}_{3}$ perovskites with $\mathrm{A}=\mathrm{Ba}, \mathrm{Y}, \mathrm{Pb}, \mathrm{La}, \mathrm{Dy}$ and $\mathrm{B}=\mathrm{Al}, \mathrm{Cr}, \mathrm{Ni}, \mathrm{Cu}, \mathrm{Ru}, \mathrm{Ce}$, is resumed in Table 1 . Barium and lead titanates prepared by a solid state reaction show a very small SSA $\left(<1 \mathrm{~m}^{2} / \mathrm{g}\right)$ [44].

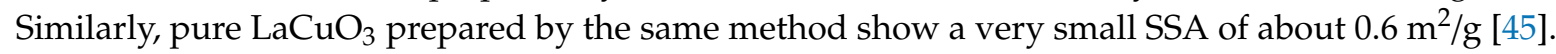
A slight increase of the SSA is observed for neat $\mathrm{LaCrO}_{3}$ and $\mathrm{LaNiO}_{3}$, but it does not exceed $5 \mathrm{~m}^{2} / \mathrm{g}$ [45]. The high values of the calcination temperatures involved in the preparation of perovskites via solid state reaction are responsible for the small values of the SSA. The utilisation of high temperatures during the calcination procedure leads to non-porous materials with a non-uniformity of the particle shape and size, and with small SSA [46]. Undoped $\mathrm{LaCrO}_{3}$ and doped $\mathrm{LaCrO}_{3}$ with different contents of $\mathrm{Mg}$ were prepared by the citrate method. The generated SSA are similar in the range of $5-7 \mathrm{~m}^{2} / \mathrm{g}$ [47]. The increase of the SSA of pristine $\mathrm{LaCrO}_{3}$ prepared by citrate method compared to the one prepared by solid state reaction (see Table 1) can be correlated with the calcination temperature, which is much lower compared to the temperature used for the preparation via solid state reaction. The addition of $\mathrm{MgO}$ to the perovskite powder leads to an increase of the SSA up to $37 \mathrm{~m}^{2} / \mathrm{g}$ [48]. SSAs in the range of $4-21 \mathrm{~m}^{2} / \mathrm{g}$ were obtained by the citrate method for $\mathrm{Fe}$ and $\mathrm{Co}$ doped $\mathrm{LaCuO}_{3}$ perovskites $[49,50]$. Pure $\mathrm{LaNiO}_{3}$ obtained by the plasmochemical method, which is based on the injection of metallic precursors into a reactor with an air plasma having a temperature in the range of 4000-6000 K, shows an SSA of $17 \mathrm{~m}^{2} / \mathrm{g}$ [51]. The freeze-drying technique was used to prepare $\mathrm{La}_{1-\mathrm{x}} \mathrm{Sr}_{\mathrm{x}} \mathrm{B}_{1-\mathrm{y}} \mathrm{Ni}_{\mathrm{y}}$ with SSA in the range of $10-16 \mathrm{~m}^{2} / \mathrm{g}[52,53]$. In this method, the solvent is directly sublimed from the solid ice into vapor, avoiding the formation of the liquid phase which can alter the morphological and chemical homogeneity of the final product [54]. 
Table 1. The influence of the synthesis method on the specific surface area (SSA) of different perovskite powders.

\begin{tabular}{|c|c|c|c|}
\hline Catalyst & Preparation Method & $\begin{array}{c}\text { SSA } \\
\left(\mathrm{m}^{2} / \mathrm{g}\right)\end{array}$ & Ref. \\
\hline $\mathrm{BaTiO}_{3}$ & Solid state reaction & 0.4 & [44] \\
\hline $\mathrm{PbTiO}_{3}$ & & 0.5 & \\
\hline $\mathrm{LaAlO}_{3}$ & Citrate & 4.0 & [55] \\
\hline $\mathrm{LaAl}_{0.95} \mathrm{Mn}_{0.05} \mathrm{O}_{3}$ & & 8.0 & \\
\hline $\mathrm{LaAl}_{0.9} \mathrm{Mn}_{0.1} \mathrm{O}_{3}$ & & 7.0 & \\
\hline $\mathrm{LaAl}_{0.8} \mathrm{Mn}_{0.2} \mathrm{O}_{3}$ & & 25.0 & \\
\hline $\mathrm{LaAl}_{0.6} \mathrm{Mn}_{0.4} \mathrm{O}_{3}$ & & 25.0 & \\
\hline $\mathrm{LaAl}_{0.4} \mathrm{Mn}_{0.6} \mathrm{O}_{3}$ & & 26.0 & \\
\hline $\mathrm{LaAl}_{0.2} \mathrm{Mn}_{0.8} \mathrm{O}_{3}$ & & 33.0 & \\
\hline $\mathrm{LaCrO}_{3}$ & Solid state reaction & 1.9 & [45] \\
\hline $\mathrm{LaCrO}_{3}$ and & Citrate & $\sim 5-7$ & [47] \\
\hline $\begin{array}{c}\operatorname{LaCr}_{1-\mathrm{x}} \mathrm{Mg}_{\mathrm{x}} \mathrm{O}_{3} \text { with } 0.1 \leq \mathrm{x} \leq 0.5 \\
\operatorname{LaCr}_{0.5} \mathrm{Mg}_{0.5} \mathrm{O}_{3}\end{array}$ & Citrate & 6.08 & [48] \\
\hline $\mathrm{LaCr}_{0.5} \mathrm{Mg}_{0.5} \mathrm{O}_{3} \cdot 2 \mathrm{MgO}$ & & 13.6 & \\
\hline $\mathrm{LaCr}_{0.5} \mathrm{Mg}_{0.5} \mathrm{O}_{3} \cdot 6 \mathrm{MgO}$ & & 24.2 & \\
\hline $\mathrm{LaCr}_{0.5} \mathrm{Mg}_{0.5} \mathrm{O}_{3} \cdot 17 \mathrm{MgO}$ & & 36.9 & \\
\hline $\mathrm{LaNiO}_{3}$ & Solid state reaction & 4.8 & [45] \\
\hline $\mathrm{LaNiO}_{3}$ & Plasmochemical & 17.0 & [51] \\
\hline $\mathrm{La}_{0.87} \mathrm{Sr}_{0.13} \mathrm{Mn}_{0.2} \mathrm{Ni}_{0.8} \mathrm{O}_{3-\mathrm{x}}$ & Freeze drying & 12.7 & [52] \\
\hline $\begin{array}{l}\mathrm{La}_{0.4} \mathrm{Sr}_{0.6} \mathrm{Mo}_{0.1} \mathrm{Ni}_{0.9} \mathrm{O}_{3} \\
\quad \text { (microstructured) }\end{array}$ & Freeze drying & 10.3 & [53] \\
\hline $\begin{array}{l}\mathrm{La}_{0.4} \mathrm{Sr}_{0.6} \mathrm{Mn}_{0.4} \mathrm{Ni}_{0.6} \mathrm{O}_{3} \\
\quad \text { (microstructured) }\end{array}$ & Freeze drying & 15.9 & [53] \\
\hline $\mathrm{LaCuO}_{3}$ & Solid state reaction & 0.6 & [45] \\
\hline $\mathrm{LaMn}_{0.8} \mathrm{Cu}_{0.2} \mathrm{O}_{3}$ & Citrate & 19.0 & [50] \\
\hline $\mathrm{LaMn}_{0.6} \mathrm{Cu}_{0.4} \mathrm{O}_{3}$ & Citrate & 14.0 & [50] \\
\hline $\mathrm{LaFe}_{0.84} \mathrm{Cu}_{0.16} \mathrm{O}_{3}$ & Citrate & 4.0 & [49] \\
\hline $\mathrm{LaCo}_{0.8} \mathrm{Cu}_{0.2} \mathrm{O}_{3}$ & Citrate & 21.0 & [38] \\
\hline $\mathrm{LaCo}_{0.6} \mathrm{Cu}_{0.4} \mathrm{O}_{3}$ & Citrate & 13.0 & [38] \\
\hline$(\mathrm{Dy}-\mathrm{Y}) \mathrm{NiO}_{3}$ & Mechanochemical & 9.5 & [51] \\
\hline
\end{tabular}

In Table 2 the influence of the preparation method on the specific surface area of lanthanide cobaltate-based perovskites is resumed. Generally, the co-precipitation method is used for both pure and doped cobaltates having rare-earth elements in the A site. The specific surface area of perovskites prepared by this method ranges from 1.6 to $8 \mathrm{~m}^{2} / \mathrm{g}[3,56,57]$. The calcination temperature of the cake (precipitate), the calcination time and the heating rate are experimental factors controlling the specific surface area. Similar values of SSA were obtained by using the same preparation method for $\mathrm{PrCOO}_{3}$, $\mathrm{NdCoO}_{3}$ and $\mathrm{GdCoO}_{3}$, respectively [56]. The citrate method is a suitable technique for cobaltate perovskites with higher specific surface area. It is frequently used for both pure and doped complex perovskites. The specific surface areas are extended over a larger range starting from $6 \mathrm{~m}^{2} / \mathrm{g}$ for pure $\mathrm{LaCoO}_{3}$ and reaching a value of $18 \mathrm{~m}^{2} / \mathrm{g}$ for Ce-doped $\mathrm{LaCoO}_{3}[50,58,59]$. Solid state reaction offers a smaller range of specific surface areas with a maximum value of $5.1 \mathrm{~m}^{2} / \mathrm{g}$ for Ba-doped $\mathrm{LaCoO}_{3}$ ( $20 \%$ of A site). Moreover, a slight increase of SSA with the increase of the ionic radii of dopants $\left(\mathrm{Ca}^{2+}, \mathrm{Sr}^{2+}, \mathrm{Ba}^{2+}\right)$ is observed [45]. Several microstructured powders of different perovskite-type materials based on the $\mathrm{La}_{1-\mathrm{x}} \mathrm{Sr}_{\mathrm{x}} \mathrm{Co}_{1-\mathrm{y}} \mathrm{B}_{\mathrm{y}} \mathrm{O}_{3}$ formula prepared by freeze-drying method were reported to show SSA ranging from 10.4 to $22.7 \mathrm{~m}^{2} / \mathrm{g}$. Yamazoe et al. reported that the freeze-drying method allows the formation of higher surface area materials compared to other thermal evaporation techniques due to its great control of evaporation processes and lower decomposition temperatures [60]. A much higher value of SSA was reported for $\mathrm{La}_{0.9} \mathrm{Ce}_{0.1} \mathrm{CoO}_{3}$ prepared by flame pyrolysis $\left(62 \mathrm{~m}^{2} / \mathrm{g}\right)$ compared to the same perovskite prepared by the citrate method $\left(10 \mathrm{~m}^{2} / \mathrm{g}\right)[58,61]$. This method implies the combustion in the flame of a solution containing the metallic precursors. It is a versatile technique which ensures an excellent control of the material crystallinity and particle size through its experimental parameters [62]. 
Table 2. The influence of the synthesis method on the specific surface area of different powder lanthanide cobaltate-based perovskites.

\begin{tabular}{|c|c|c|c|}
\hline Catalyst & Preparation Method & $\begin{array}{l}\text { SSA } \\
\left(\mathrm{m}^{2} / \mathrm{g}\right)\end{array}$ & Ref. \\
\hline $\mathrm{LaCoO}_{3}$ & Co-precipitation & 3.5 & [56] \\
\hline $\mathrm{LaCoO}_{3}$ & Co-precipitation & 8.0 & [57] \\
\hline $\mathrm{LaCoO}_{3}$ & Solid state reaction & 3.0 & [45] \\
\hline $\mathrm{LaCoO}_{3}$ & Citrate & 11.3 & [58] \\
\hline $\mathrm{LaCoO}_{3}$ & Citrate & 6.0 & [59] \\
\hline $\mathrm{LaCoO}_{3}$ & Citrate & 15.0 & [50] \\
\hline $\mathrm{LaCoO}_{3}$ & Combustion & 5.7 & [63] \\
\hline $\mathrm{LaCoO}_{3}$ & $\begin{array}{l}\text { Ultrasound spray } \\
\text { combustion }\end{array}$ & 5.5 & [64] \\
\hline $\mathrm{LaCoO}_{3}$ & Flame-pyrolysis & 43.0 & [61] \\
\hline $\mathrm{LaCoO}_{3+x}$ & Flame-hydrolysis & $15.6-22.8$ & [65] \\
\hline $\mathrm{La}_{0.8} \mathrm{Ca}_{0.2} \mathrm{CoO}_{3}$ & Solid state reaction & 2.0 & [45] \\
\hline $\mathrm{La}_{0.9} \mathrm{Sr}_{0.1} \mathrm{CoO}_{3}$ & Flame-pyrolysis & 52.0 & [61] \\
\hline $\mathrm{La}_{0.8} \mathrm{Sr}_{0.2} \mathrm{CoO}_{3}$ & Solid state reaction & 4.7 & [45] \\
\hline $\mathrm{La}_{0.8} \mathrm{Sr}_{0.2} \mathrm{CoO}_{3}{ }^{\mathrm{a}}$ & Freeze-drying & 16.5 & [53] \\
\hline $\mathrm{La}_{0.66} \mathrm{Sr}_{0.34} \mathrm{CoO}_{3} \mathrm{a}$ & & 17.4 & \\
\hline $\mathrm{La}_{0.6} \mathrm{Sr}_{0.4} \mathrm{CoO}_{3}$ & Solid state reaction & 3.6 & [45] \\
\hline $\mathrm{La}_{0.8} \mathrm{Ba}_{0.2} \mathrm{CoO}_{3}$ & & 5.1 & \\
\hline $\mathrm{La}_{0.53} \mathrm{Sr}_{0.47} \mathrm{Fe}_{0.2} \mathrm{Co}_{0.8} \mathrm{O}_{3}{ }^{\mathrm{a}}$ & Freeze-drying & 13.4 & [53] \\
\hline $\mathrm{La}_{0.4} \mathrm{Sr}_{0.6} \mathrm{Fe}_{0.4} \mathrm{Co}_{0.6} \mathrm{O}_{3}$ a & & 10.4 & \\
\hline $\mathrm{La}_{0.55} \mathrm{Sr}_{0.45} \mathrm{Mn}_{0.1} \mathrm{Ni}_{0.3} \mathrm{Co}_{0.6} \mathrm{O}_{3}{ }^{\mathrm{a}}$ & & 15.0 & \\
\hline $\mathrm{La}_{0.5} \mathrm{Sr}_{0.5} \mathrm{Fe}_{0.04} \mathrm{Ni}_{0.1} \mathrm{Co}_{0.86} \mathrm{O}_{3} \mathrm{a}$ & & 19.6 & \\
\hline $\mathrm{La}_{0.55} \mathrm{Sr}_{0.45} \mathrm{Fe}_{0.05} \mathrm{Ni}_{0.3} \mathrm{Co}_{0.65} \mathrm{O}_{3}{ }^{\mathrm{a}}$ & & 15.2 & \\
\hline $\mathrm{La}_{0.66} \mathrm{Sr}_{0.34} \mathrm{Ni}_{0.3} \mathrm{Co}_{0.7} \mathrm{O}_{3}$ a & & 18.8 & \\
\hline $\mathrm{La}_{0.7} \mathrm{Sr}_{0.3} \mathrm{Ni}_{0.3} \mathrm{Co}_{0.7} \mathrm{O}_{3}$ a & & 22.7 & \\
\hline $\mathrm{La}_{0.95} \mathrm{Ce}_{0.05} \mathrm{CoO}_{3}$ & Citrate & 8.7 & [58] \\
\hline $\mathrm{La}_{0.9} \mathrm{Ce}_{0.1} \mathrm{CoO}_{3}$ & & 10.0 & \\
\hline $\mathrm{La}_{0.9} \mathrm{Ce}_{0.1} \mathrm{CoO}_{3}$ & Flame-pyrolysis & 62.0 & [61] \\
\hline $\mathrm{La}_{0.8} \mathrm{Ce}_{0.2} \mathrm{CoO}_{3}$ & Solid state reaction & 3.1 & [45] \\
\hline $\mathrm{La}_{0.8} \mathrm{Ce}_{0.2} \mathrm{CoO}_{3}$ & Citrate & 14.2 & [58] \\
\hline $\mathrm{La}_{0.7} \mathrm{Ce}_{0.3} \mathrm{CoO}_{3}$ & & 14.3 & \\
\hline $\mathrm{La}_{0.6} \mathrm{Ce}_{0.4} \mathrm{CoO}_{3}$ & & 11.6 & \\
\hline $\mathrm{La}_{0.5} \mathrm{Ce}_{0.5} \mathrm{CoO}_{3}$ & & 18.0 & \\
\hline $\mathrm{PrCOO}_{3}$ & Co-precipitation & 5.1 & [56] \\
\hline $\mathrm{NdCoO}_{3}$ & & 1.6 & \\
\hline $\mathrm{GdCoO}_{3}$ & & 2.1 & \\
\hline
\end{tabular}

Manganates represent a class of perovskite materials having manganese in B site positions $\left(\mathrm{AMnO}_{3}\right)$. The effect of the synthesis method on the SSA of lanthanide manganate-based perovskites is presented in Table 3. Compared to cobaltates, the SSA of manganates prepared by co-precipitation are higher with a maximum value of ca. $15 \mathrm{~m}^{2} / \mathrm{g}$ for pure $\mathrm{LaMnO}_{3}$ [3]. For manganese-based perovskites, one of the highest values of the SSA $\left(68 \mathrm{~m}^{2} / \mathrm{g}\right)$ was obtained by the citrate method, which consisted of adding citric acid and ethylene glycol to a solution containing lanthanum and manganese nitrates. It has been observed that the specific surface area increases with the citric acid etching time [66]. A detailed study concerning both the neat and Mn-doped $\mathrm{LaAlO}_{3}$ perovskites reported that SSA increases with the $\mathrm{Mn}$ content reaching a maximum value of $33 \mathrm{~m}^{2} / \mathrm{g}$ for $\mathrm{LaAl}_{0.2} \mathrm{Mn}_{0.8} \mathrm{O}_{3}$. When aluminum cations are completely replaced with manganese cations, SSA decreases to $22 \mathrm{~m}^{2} / \mathrm{g}$ [55]. Pure $\mathrm{LaMnO}_{3}$ prepared by flame-pyrolysis shows an SSA of $56 \mathrm{~m}^{2} / \mathrm{g}$. By substituting (10 at.\%) of La cations with $\mathrm{Sr}^{2+}$, a slight decrease of the SSA can be observed $\left(51 \mathrm{~m}^{2} / \mathrm{g}\right)$. By increasing the dopant concentration (20 at.\%), the SSA increases up to $70 \mathrm{~m}^{2} / \mathrm{g}$. In contrast to Ce-doped cobaltates prepared by flame-pyrolysis $\left(62 \mathrm{~m}^{2} / \mathrm{g}\right), \mathrm{La}_{0.9} \mathrm{Ce}_{0.1} \mathrm{MnO}_{3}$ shows a higher SSA of about $84 \mathrm{~m}^{2} / \mathrm{g}$, with a particle size of 30-45 nm [61]. Yu et al. reported an accurate study concerning the effect of the preparation method on the SSA of Pd-doped $\mathrm{LaMnO}_{3}$ [67] showing that an inappropriate ratio between the metallic precursors and the organic fuel in the combustion synthesis leads to a very low SSA $\left(1 \mathrm{~m}^{2} / \mathrm{g}\right)$, while higher SSA can be obtained by using amorphous citrate $\left(12 \mathrm{~m}^{2} / \mathrm{g}\right)$ and flame pyrolysis $\left(32 \mathrm{~m}^{2} / \mathrm{g}\right)$ methods. The ultrasonic spray combustion method generates $\mathrm{Pd}$-doped $\mathrm{LaMnO}_{3}$ perovskite material showing the highest SSA $\left(39 \mathrm{~m}^{2} / \mathrm{g}\right)$. In contrast to the classical combustion synthesis, this method uses an ultrasonic 
spray gun to initiate the reaction [68]. Notably, the crystal structure of the perovskite depends on the preparation method as well. Indeed, a rhombohedral crystal structure was obtained via ultrasonic spray combustion and citrate methods, while combustion and flame pyrolysis methods generated an orthorombic perovskite structure [67]. Ciambelli et al. reported the preparation of Ce- and Y-doped rare earth manganates by the mechanochemical method. Starting from oxide and carbonate precursors, the resulting materials showed SSAs of 14 and $19 \mathrm{~m}^{2} / \mathrm{g}$, respectively [51].

Table 3. The influence of the synthesis method on the specific surface area of different lanthanide manganate-based perovskite powders.

\begin{tabular}{|c|c|c|c|}
\hline Catalyst & Preparation Method & $\begin{array}{c}\text { SSA } \\
\left(\mathrm{m}^{2} / \mathrm{g}\right)\end{array}$ & Ref. \\
\hline $\mathrm{LaMnO}_{3}$ & Co-precipitation & $\sim 15.0$ & [3] \\
\hline $\mathrm{LaMnO}_{3+x}$ & Co-precipitation & 8.0 & [69] \\
\hline $\mathrm{LaMnO}_{3}$ & Co-precipitation & 7.0 & [57] \\
\hline $\mathrm{LaMnO}_{3}$ & Co-precipitation & 11.0 & [70] \\
\hline $\mathrm{LaMnO}_{3}$ & Solid state reaction & 4.0 & [45] \\
\hline $\mathrm{LaMnO}_{3}$ & Citrate & 5.6 & [49] \\
\hline $\mathrm{LaMnO}_{3}$ & Citrate & 20.0 & [71] \\
\hline $\mathrm{LaMnO}_{3}$ & Citrate & 20.0 & [72] \\
\hline $\mathrm{LaMnO}_{3}$ & Citrate & 22.0 & [55] \\
\hline $\mathrm{LaMnO}_{3}$ & Citrate & 68.0 & [66] \\
\hline $\mathrm{LaMnO}_{3}$ & Citrate & 22.0 & [50] \\
\hline $\mathrm{LaMnO}_{3+x}$ & Flame-hydrolysis & $15.6-22.8$ & [65] \\
\hline $\mathrm{LaMnO}_{3}$ & Flame-pyrolysis & 56.0 & [61] \\
\hline $\mathrm{LaMnO}_{3}$ & Ultrasound spray combustion & 21.8 & [64] \\
\hline $\mathrm{La}_{0.8} \mathrm{Ca}_{0.2} \mathrm{MnO}_{3}$ & Solid state reaction & 6.7 & [45] \\
\hline $\mathrm{La}_{0.9} \mathrm{Sr}_{0.1} \mathrm{MnO}_{3}$ & Flame-pyrolysis & 51.0 & [61] \\
\hline $\mathrm{La}_{0.8} \mathrm{Sr}_{0.2} \mathrm{MnO}_{3}$ & Flame-pyrolysis & 70.0 & [61] \\
\hline $\mathrm{La}_{0.8} \mathrm{Sr}_{0.2} \mathrm{MnO}_{3}$ & Solid state reaction & 8.6 & [45] \\
\hline $\mathrm{La}_{0.8} \mathrm{Sr}_{0.2} \mathrm{MnO}_{3+\mathrm{x}}$ & Co-precipitation & 5.0 & [73] \\
\hline $\mathrm{La}_{0.6} \mathrm{Sr}_{0.4} \mathrm{MnO}_{3}$ & Citrate & 18.7 & [71] \\
\hline $\mathrm{La}_{0.6} \mathrm{Sr}_{0.4} \mathrm{MnO}_{3}$ & Solid state reaction & 3.3 & [45] \\
\hline $\mathrm{La}_{0.6} \mathrm{Sr}_{0.4} \mathrm{MnO}_{3}{ }^{\mathrm{a}}$ & Citrate & 4.32 & [74] \\
\hline $\mathrm{SrTi}_{0.8} \mathrm{Zr}_{0.1} \mathrm{Mn}_{0.1} \mathrm{O}_{3}$ & Co-precipitation & 15.0 & [75] \\
\hline $\mathrm{La}(\mathrm{Mn}, \mathrm{Pd}) \mathrm{O}_{3}(2.9$ wt. $\%$ Pd $)$ & Citrate method & 12.0 & [67] \\
\hline $\mathrm{La}(\mathrm{Mn}, \mathrm{Pd}) \mathrm{O}_{3}(2.32 \mathrm{wt} . \% \mathrm{Pd})$ & Flame pyrolysis & 32.0 & [67] \\
\hline $\mathrm{La}(\mathrm{Mn}, \mathrm{Pd}) \mathrm{O}_{3}(2.37$ wt. $\% \mathrm{Pd})$ & Solution combustion & 1.0 & [67] \\
\hline $\mathrm{La}(\mathrm{Mn}, \mathrm{Pd}) \mathrm{O}_{3}(2.11$ wt. $\% \mathrm{Pd})$ & Ultrasonic spray combustion & 39.0 & [67] \\
\hline $\mathrm{La}_{0.9} \mathrm{Ce}_{0.1} \mathrm{MnO}_{3}$ & Citrate & 32.0 & [71] \\
\hline $\mathrm{La}_{0.9} \mathrm{Ce}_{0.1} \mathrm{MnO}_{3}$ & Flame-pyrolysis & 84.0 & [61] \\
\hline$(\mathrm{La}-\mathrm{Ce}) \mathrm{MnO}_{3}$ & Mechanochemical & 19.0 & [51] \\
\hline $\mathrm{PrMnO}_{3+x}$ & Co-precipitation & 2.5 & [69] \\
\hline $\mathrm{NdMnO}_{3+x}$ & Co-precipitation & 2.4 & [69] \\
\hline $\mathrm{NdMnO}_{3}$ & Citrate & 20.0 & [72] \\
\hline $\mathrm{SmMnO}_{3}$ & & 19.0 & \\
\hline $\mathrm{Sm}_{0.9} \mathrm{Sr}_{0.1} \mathrm{MnO}_{3}$ & & 20.0 & \\
\hline $\mathrm{Sm}_{0.7} \mathrm{Sr}_{0.3} \mathrm{MnO}_{3}$ & & 14.0 & \\
\hline $\mathrm{Sm}_{0.5} \mathrm{Sr}_{0.5} \mathrm{MnO}_{3}$ & & 13.0 & \\
\hline $\mathrm{La}_{0.9} \mathrm{Eu}_{0.1} \mathrm{MnO}_{3}$ & Citrate & 26.4 & [71] \\
\hline $\mathrm{GdMnO}_{3+\mathrm{x}}$ & Co-precipitation & 5.3 & [69] \\
\hline$(\mathrm{Dy}-\mathrm{Y}) \mathrm{MnO}_{3}$ & Mechanochemical & 14.0 & [51] \\
\hline
\end{tabular}

a 1 D non-porous.

Table 4 shows the effect of the synthesis method on the SSA for lanthanide ferrite-based perovskites. The co-precipitation method leads to $\mathrm{LaFeO}_{3}\left(21 \mathrm{~m}^{2} / \mathrm{g}\right)$ solids having even higher SSA than manganates $\left(15 \mathrm{~m}^{2} / \mathrm{g}\right)$ and cobaltates $\left(8 \mathrm{~m}^{2} / \mathrm{g}\right)[3,57,76]$. The citrate method is one of the most used preparation techniques for pure $\mathrm{LaFeO}_{3}$ and doped $\mathrm{LaFeO}_{3}$ perovskites. Pure $\mathrm{LaFeO}_{3}$ showing the SSA of $2.9 \mathrm{~m}^{2} / \mathrm{g}$ was prepared by this method. It was observed that the SSA increases with the concentration of $\mathrm{Mg}^{2+}$ used as B-site dopant. This tendency is maintained for a maximum $\mathrm{Mg}^{2+}$ concentration of 40 at. $\%$. A further increase of the dopant content leads to the reduction of SSA [77]. A similar value of the SSA for neat $\mathrm{LaFeO}_{3}$ prepared via citrate method was reported elsewhere [78]. No changes of the SSA were observed for $\mathrm{La}_{0.7} \mathrm{Ca}_{0.3} \mathrm{FeO}_{3}$ compared to simple $\mathrm{LaFeO}_{3}$. However, when increasing the $\mathrm{Ca}^{2+}$ content to 50 at.\%, the SSA dramatically decreases down to $0.7 \mathrm{~m}^{2} / \mathrm{g}$. Other publications report values of SSA of ca. $20 \mathrm{~m}^{2} / \mathrm{g}$ for undoped $\mathrm{LaFeO}_{3}$ prepared by the citrate method. Also, it increases to ca. $38 \mathrm{~m}^{2} / \mathrm{g}$ for Ca-doped 
$\mathrm{LaFeO}_{3}[76,79]$. The substantial differences between the SSA of the same perovskite materials can be correlated to the calcination temperature used during the preparation procedure. Materials with smaller SSA were calcined at $800{ }^{\circ} \mathrm{C}$ for $5 \mathrm{~h}$, while the others were obtained at $700{ }^{\circ} \mathrm{C}$ in $6 \mathrm{~h}[76,79]$. Pd-doped $\mathrm{LaFeO}_{3}$ shows similar values of SSA as Pd-doped $\mathrm{LaMnO}_{3}$, when prepared via citrate and combustion methods. However, the SSA decreases for Pd-doped $\mathrm{LaFeO}_{3}$ prepared by flame pyrolysis and ultrasonic spray combustion methods. In contrast to Pd-doped $\mathrm{LaMnO}_{3}$, the formation of the orthorombic crystal structure of $\mathrm{Pd} \mathrm{LaFeO}_{3}$ is independent on the preparation method [67]. Also, the mechanochemical method is used for the preparation of doped ferrites. The resulting materials possess SSA smaller than $10 \mathrm{~m}^{2} / \mathrm{g}$ [51].

Table 4. The influence of the synthesis method on the specific surface area of lanthanide ferrite-based perovskite powders.

\begin{tabular}{|c|c|c|c|}
\hline Catalyst & Preparation Method & $\begin{array}{c}\text { SSA } \\
\left(\mathrm{m}^{2} / \mathrm{g}\right)\end{array}$ & Ref. \\
\hline $\mathrm{LaFeO}_{3}$ & Co-precipitation & 10.0 & {$[57]$} \\
\hline $\mathrm{LaFeO}_{3}$ & Co-precipitation & 5.5 & [3] \\
\hline $\mathrm{LaFeO}_{3+x}$ & Co-precipitation & 3.5 & [69] \\
\hline $\mathrm{LaFeO}_{3}$ & Co-precipitation & 20.9 & [76] \\
\hline $\mathrm{LaFeO}_{3}$ & Solid state reaction & 3.1 & [45] \\
\hline $\mathrm{LaFeO}_{3}$ & Citrate & 2.9 & [77] \\
\hline $\mathrm{LaFeO}_{3}$ & Citrate & 3.0 & [78] \\
\hline $\mathrm{LaFeO}_{3}$ & Citrate & 19.5 & {$[76]$} \\
\hline $\mathrm{LaFeO}_{3}$ & Citrate & 21.0 & [79] \\
\hline $\mathrm{LaFeO}_{3}$ & Combustion & 3.0 & [63] \\
\hline $\mathrm{LaFeO}_{3+x}$ & Flame-hydrolysis & 15.6 & [65] \\
\hline $\mathrm{LaFeO}_{3}$ & Flame-pyrolysis & 38.0 & [61] \\
\hline $\mathrm{LaFeO}_{3}$ & Ultrasound spray combustion & 9.8 & [64] \\
\hline $\mathrm{LaFe}_{0.9} \mathrm{Mg}_{0.1} \mathrm{O}_{3}$ & Citrate & 4.3 & [77] \\
\hline $\mathrm{LaFe}_{0.8} \mathrm{Mg}_{0.2} \mathrm{O}_{3}$ & & 5.5 & \\
\hline $\mathrm{LaFe}_{0.7} \mathrm{Mg}_{0.3} \mathrm{O}_{3}$ & & 7.9 & \\
\hline $\mathrm{LaFe}_{0.6} \mathrm{Mg}_{0.4} \mathrm{O}_{3}$ & & 9.7 & \\
\hline $\mathrm{LaFe}_{0.5} \mathrm{Mg}_{0.5} \mathrm{O}_{3}$ & & 5.3 & \\
\hline $\mathrm{La}_{0.9} \mathrm{Ca}_{0.1} \mathrm{FeO}_{3}$ & Co-precipitation & 14.0 & [76] \\
\hline $\mathrm{La}_{0.9} \mathrm{Ca}_{0.1} \mathrm{FeO}_{3}$ & Citrate & 6.0 & [78] \\
\hline $\mathrm{La}_{0.9} \mathrm{Ca}_{0.1} \mathrm{FeO}_{3}$ & Citrate & 17.8 & [76] \\
\hline $\mathrm{La}_{0.9} \mathrm{Ca}_{0.1} \mathrm{FeO}_{3}$ & Citrate & 38.0 & [79] \\
\hline $\mathrm{La}_{0.8} \mathrm{Ca}_{0.2} \mathrm{FeO}_{3}$ & Co-precipitation & 8.3 & {$[76]$} \\
\hline $\mathrm{La}_{0.8} \mathrm{Ca}_{0.2} \mathrm{FeO}_{3}$ & Citrate & 5.0 & [78] \\
\hline $\mathrm{La}_{0.8} \mathrm{Ca}_{0.2} \mathrm{FeO}_{3}$ & Citrate & 38.6 & [76] \\
\hline $\mathrm{La}_{0.8} \mathrm{Ca}_{0.2} \mathrm{FeO}_{3}$ & Citrate & 38.0 & [79] \\
\hline $\mathrm{La}_{0.7} \mathrm{Ca}_{0.3} \mathrm{FeO}_{3}$ & Co-precipitation & 5.4 & [76] \\
\hline $\mathrm{La}_{0.7} \mathrm{Ca}_{0.3} \mathrm{FeO}_{3}$ & Citrate & 3.0 & [78] \\
\hline $\mathrm{La}_{0.7} \mathrm{Ca}_{0.3} \mathrm{FeO}_{3}$ & Citrate & 38.6 & [76] \\
\hline $\mathrm{La}_{0.7} \mathrm{Ca}_{0.3} \mathrm{FeO}_{3}$ & Citrate & 38.0 & [79] \\
\hline $\mathrm{La}_{0.6} \mathrm{Ca}_{0.4} \mathrm{FeO}_{3}$ & Co-precipitation & 8.3 & [76] \\
\hline $\mathrm{La}_{0.6} \mathrm{Ca}_{0.4} \mathrm{FeO}_{3}$ & Citrate & 31.2 & [76] \\
\hline $\mathrm{La}_{0.6} \mathrm{Ca}_{0.4} \mathrm{FeO}_{3}$ & Citrate & 5.0 & [78] \\
\hline $\mathrm{La}_{0.6} \mathrm{Ca}_{0.4} \mathrm{FeO}_{3}$ & Citrate & 33.0 & [79] \\
\hline $\mathrm{La}_{0.5} \mathrm{Ca}_{0.5} \mathrm{FeO}_{3}$ & Citrate & 0.7 & [78] \\
\hline $\mathrm{La}_{0.8} \mathrm{Sr}_{0.2} \mathrm{FeO}_{3}$ & Solid state reaction & 4.7 & [45] \\
\hline $\mathrm{La}(\mathrm{Fe}, \mathrm{Pd}) \mathrm{O}_{3}(2.4$ wt. $\% \mathrm{Pd})$ & Citrate & 14.0 & [67] \\
\hline $\mathrm{La}(\mathrm{Fe}, \mathrm{Pd}) \mathrm{O}_{3}(2.28$ wt. $\% \mathrm{Pd})$ & Flame pyrolysis & 22.0 & \\
\hline $\mathrm{La}(\mathrm{Fe}, \mathrm{Pd}) \mathrm{O}_{3}(1.25$ wt. $\% \mathrm{Pd})$ & Ultrasonic spray combustion & 27.0 & \\
\hline $\mathrm{La}(\mathrm{Fe}, \mathrm{Pd}) \mathrm{O}_{3}(2.47$ wt. $\% \mathrm{Pd})$ & Solution combustion & 1.6 & \\
\hline$(\mathrm{La}-\mathrm{Ce}) \mathrm{FeO}_{3}$ & Mechanochemical & 5.3 & {$[51]$} \\
\hline $\mathrm{PrFeO}_{3+x}$ & Co-precipitation & 5.8 & [69] \\
\hline $\mathrm{NdFeO}_{3+x}$ & Co-precipitation & 4.5 & [69] \\
\hline $\mathrm{NdFeO}_{3}$ & Citrate & 2.3 & [77] \\
\hline $\mathrm{SmFeO}_{3}$ & Citrate & 4.3 & [77] \\
\hline $\mathrm{GdFeO}_{3+x}$ & Co-precipitation & 5.6 & [69] \\
\hline$(\mathrm{Dy}-\mathrm{Y}) \mathrm{FeO}_{3}$ & Mechanochemical & 8.6 & {$[51]$} \\
\hline
\end{tabular}


The effect of the preparation method on the SSA of supported perovkites is resumed in Table 5. The wet impregnation technique was used to stabilize commercial $\gamma-\mathrm{Al}_{2} \mathrm{O}_{3}$ (having initial SSA of $200 \mathrm{~m}^{2} / \mathrm{g}$ ) with $5 \mathrm{wt} . \% \mathrm{La}_{2} \mathrm{O}_{3}$. Lanthanum nitrate, manganese acetate and urea were used to load the previously prepared support with $30 \% \mathrm{LaMnO}_{3}$ by using the deposition technique. This method is based on the precipitation of the active phase, which in this case is $\mathrm{LaMnO}_{3}$ perovskite, to the support surface. Finally, the sample was dried at $120^{\circ} \mathrm{C}$ and then calcined in air for $3 \mathrm{~h}$ at $800{ }^{\circ} \mathrm{C}$. The resulting material shows an SSA of $88 \mathrm{~m}^{2} / \mathrm{g}$. Yet, the calcination temperature is not enough to obtain a pure perovskite, tiny amounts of $\mathrm{La}_{2} \mathrm{O}_{3}$ and $\mathrm{La}(\mathrm{OH})_{3}$ side-phases being observed by X-ray diffraction. MgO-supported $\mathrm{LaMnO}_{3}$ with an SSA of $25 \mathrm{~m}^{2} / \mathrm{g}$ was also prepared by the same method [70]. $\mathrm{La}_{0.8} \mathrm{Sr}_{0.2} \mathrm{MnO}_{3}$ was successfully dispersed on different $\mathrm{MAl}_{2} \mathrm{O}_{4}$ spinels supports $(\mathrm{M}=\mathrm{Mg}, \mathrm{Ni}, \mathrm{Co})$ via wet impregnation technique. The perovskite loading was $20 \mathrm{wt} . \%$ and the SSA varies between 18 and $34 \mathrm{~m}^{2} / \mathrm{g}$ [73]. Similar SSA were obtained for Ag-doped $\mathrm{LaMnO}_{3}$ loading metallic foils made of $\mathrm{Fe}-\mathrm{Cr}$-Al using the same impregnation technique. Before the impregnation, the metallic foil was washcoated with $84.8 \% \mathrm{Al}_{2} \mathrm{O}_{3}, 14.4 \% \mathrm{TiO}_{2}, 0.8 \% \mathrm{La}_{2} \mathrm{O}_{3}$ through the citrate method [80]. Neat $\mathrm{LaFeO}_{3}$ prepared via citrate method was dispersed on similar supports, leading to materials with SSA of $7.7 \mathrm{~m}^{2} / \mathrm{g}$ [81]. The highest specific surface area was obtained for $\mathrm{ZrO}_{2}$-supported $\mathrm{LaMnO}_{3}\left(132.5 \mathrm{~m}^{2} / \mathrm{g}\right)$ [82].

Table 5. The effect of the preparation methods on the SSA of supported perovskites.

\begin{tabular}{|c|c|c|c|c|c|}
\hline Catalyst & Support & $\begin{array}{l}\text { Morphology } \\
\text { of the Support }\end{array}$ & Preparation Method & $\begin{array}{c}\text { SSA } \\
\left(\mathrm{m}^{2} / \mathrm{g}\right)\end{array}$ & Ref. \\
\hline $\mathrm{LaMnO}_{3}$ & foil $\mathrm{Fe}_{2} \mathrm{Cr}_{20} \mathrm{Al}_{5}$ & monolith & Wet impregnation & 23.3 & [80] \\
\hline $\mathrm{LaMnO}_{3}$ & $\mathrm{ZrO}_{2}$ & powder & $\begin{array}{l}\text { Solution combustion } \\
\text { method }\end{array}$ & 132.5 & [82] \\
\hline $30 \% \mathrm{LaMnO}_{3}$ & $\left(5 \% \mathrm{La}_{2} \mathrm{O}_{3} / \mathrm{Al}_{2} \mathrm{O}_{3}\right)$ & powder & $\begin{array}{l}\text { Deposition } \\
\text { precipitation }\end{array}$ & 88.0 & [70] \\
\hline $20 \% \mathrm{LaMnO}_{3}$ & $\mathrm{MgO}$ & & & 25.0 & [70] \\
\hline $\mathrm{La}_{0.8} \mathrm{Sr}_{0.2} \mathrm{MnO}_{3+\mathrm{x}}$ & $\mathrm{MgAl}_{2} \mathrm{O}_{4}$ & powder & Wet impregnation & 34.0 & [73] \\
\hline $\mathrm{La}_{0.8} \mathrm{Sr}_{0.2} \mathrm{MnO}_{3+\mathrm{x}}$ & $\mathrm{NiAl}_{2} \mathrm{O}_{4}$ & & & 22.0 & \\
\hline $\mathrm{La}_{0.8} \mathrm{Sr}_{0.2} \mathrm{MnO}_{3+\mathrm{x}}$ & $\mathrm{CoAl}_{2} \mathrm{O}_{4}$ & & & 18.0 & \\
\hline $\mathrm{La}_{0.95} \mathrm{Ag}_{0.05} \mathrm{MnO}_{3}$ & foil $\mathrm{Fe}_{2} \mathrm{Cr}_{20} \mathrm{Al}_{5}$ & monolith & Wet impregnation & 27.4 & [80] \\
\hline $\mathrm{La}_{0.9} \mathrm{Ag}_{0.1} \mathrm{MnO}_{3}$ & & & & 30.9 & \\
\hline $\mathrm{La}_{0.8} \mathrm{Ag}_{0.2} \mathrm{MnO}_{3}$ & & & & 29.4 & \\
\hline $\mathrm{La}_{0.7} \mathrm{Ag}_{0.3} \mathrm{MnO}_{3}$ & & & & 31.5 & \\
\hline $\mathrm{LaFeO}_{3}$ & $\operatorname{FeCr}(20 \%) \operatorname{Al}(5 \%)$ & monolith & Citrate method & 7.7 & [81] \\
\hline $\mathrm{La}_{0.66} \mathrm{Sr}_{0.34} \mathrm{Ni}_{0.29} \mathrm{Co}_{0.69} \mathrm{Mn}_{0.02} \mathrm{O}_{3}(20 \%)$ & $\left(47 \% \mathrm{Al}_{2} \mathrm{O}_{3}-52 \% \mathrm{SiO}_{2}\right)$ & fiber & Freeze-drying & 18.0 & {$[83]$} \\
\hline $\mathrm{La}_{0.66} \mathrm{Sr}_{0.34} \mathrm{Ni}_{0.29} \mathrm{Co}_{0.69} \mathrm{Mn}_{0.02} \mathrm{O}_{3}(15 \%)$ & $\left(47 \% \mathrm{Al}_{2} \mathrm{O}_{3}-52 \% \mathrm{SiO}_{2}\right)$ & & & 23.0 & \\
\hline $\mathrm{La}_{0.66} \mathrm{Sr}_{0.34} \mathrm{Ni}_{0.29} \mathrm{Co}_{0.69} \mathrm{Fe}_{0.02} \mathrm{O}_{3}(27 \%)$ & $\left(95 \% \mathrm{Al}_{2} \mathrm{O}_{3}-5 \% \mathrm{SiO}_{2}\right)$ & & & 27.0 & \\
\hline $\mathrm{La}_{0.66} \mathrm{Sr}_{0.34} \mathrm{Ni}_{0.29} \mathrm{Co}_{0.69} \mathrm{Fe}_{0.02} \mathrm{O}_{3}(14 \%)$ & $\left(95 \% \mathrm{Al}_{2} \mathrm{O}_{3}-5 \% \mathrm{SiO}_{2}\right)$ & & & 22.0 & \\
\hline $\mathrm{La}_{0.66} \mathrm{Sr}_{0.34} \mathrm{Ni}_{0.29} \mathrm{Co}_{0.69} \mathrm{Fe}_{0.02} \mathrm{O}_{3}(15 \%)$ & $\left(47 \% \mathrm{Al}_{2} \mathrm{O}_{3}-52 \% \mathrm{SiO}_{2}\right)$ & & & 24.0 & \\
\hline $\mathrm{La}_{0.66} \mathrm{Sr}_{0.34} \mathrm{Ni}_{0.29} \mathrm{Co}_{0.69} \mathrm{Fe}_{0.02} \mathrm{O}_{3}(12 \%)$ & $\left(47 \% \mathrm{Al}_{2} \mathrm{O}_{3}-52 \% \mathrm{SiO}_{2}\right)$ & & & 27.0 & \\
\hline
\end{tabular}

\subsection{Thin Films Manufacturing Using Laser-Based Techniques}

\subsubsection{Pulsed Laser Deposition (PLD)}

Pulsed laser deposition (PLD) is a technique belonging to the physical vapor deposition (PVD) class which takes place in a vacuum chamber. The PLD setup is schematically presented in Figure 3. 


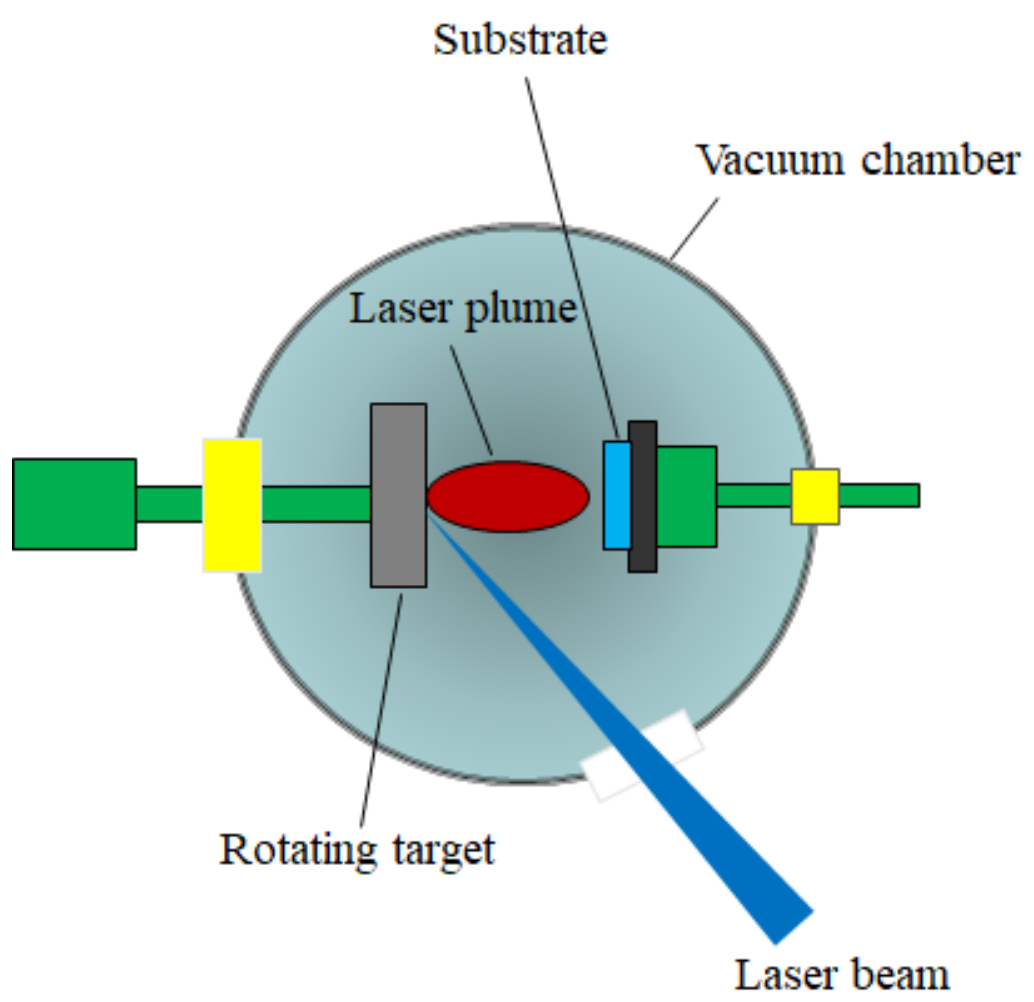

Figure 3. Pulsed laser deposition (PLD) technique scheme Adapted from Ref. [84].

A pulsed laser beam is focused onto the surface of a target consisting of the desired material to be deposited. When the laser pulses have high enough energy density, a plasma plume forms at the target surface as an effect of vaporizing or ablating small parts from it. The flux of material necessary for the film growth is provided by the ablation plume and it is collected on a substrate. In other words, the deposition process using laser ablation is based on the vaporization of the target material, followed by the deposition of the vaporized material onto a collecting substrate. The substrate is situated at a well-known distance from the target and it is placed parallel to the target, as can be seen in Figure $4[85,86]$.

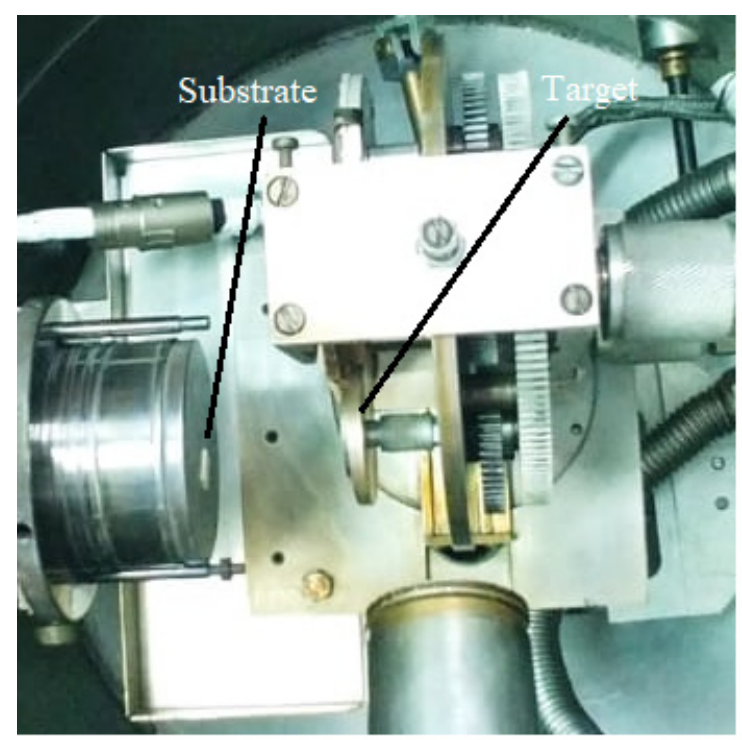

Figure 4. Photograph of the PLD setup: the heated substrate and the material target. 
The fundamental processes taking place during the laser ablation are as follows: the heating of the irradiated material; the melting, evaporation or sublimation of the heated material; the formation of the plume and, finally, the plume expansion. One of the most important ablation parameters is the energy density of the laser pulse or its fluence $\left(\mathrm{J} / \mathrm{cm}^{2}\right)$. The preparation of thin films by using PLD can be performed both in a vacuum and in a gas atmosphere, which influences the deposition process. Figure 5 displays a photograph of a $\mathrm{TiO}_{2}$ target $[85,86]$.

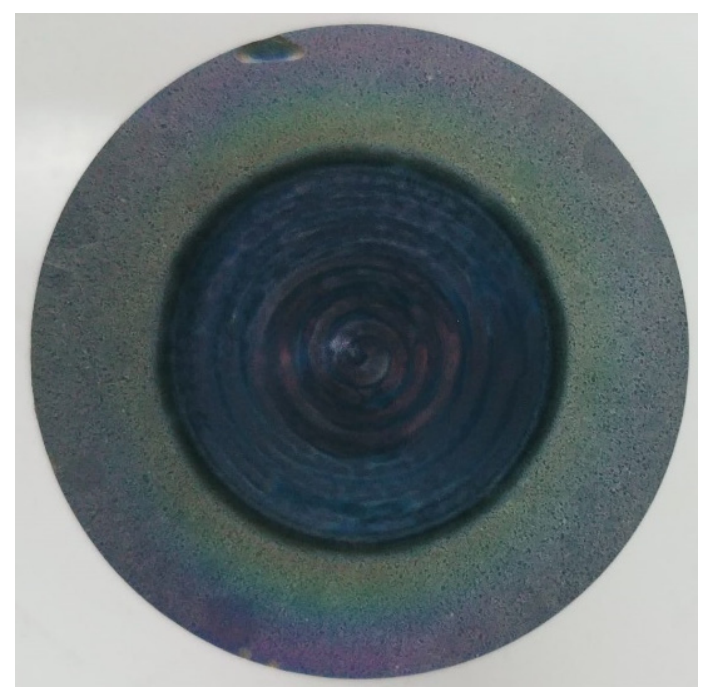

Figure 5. Photograph of a $\mathrm{TiO}_{2}$ target.

Pulsed laser deposition is a non-conventional technique, relatively simple and suitable for the production of thin films that can be successfully applied for many classes of materials when other techniques fail. It presents the following advantages:

- the laser radiation can be well focused on very small spot sizes at the target surface, increasing in this way the efficiency, the control and the flexibility of the process;

- the deposition chamber can be considered a "clean reactor" because the energy source (laser) is external, being independent of the deposition medium; also, the laser parameters (energy density and wavelength) can be easily adjusted to ensure the reproducibility of the sample preparation;

- it is a simple and versatile technique from the point of view of experimental achievement, offering the possibility to obtain all kind of materials (complex stoichiometry, organo-metallic compounds);

- the properties of the obtained thin films (thickness, crystalline structure, stoichiometry and composition) can be rigorously controlled, because they depend on the laser parameters (wavelength, laser fluence, the spot area, the duration of pulse, the repetition rate etc.) which are easily controlled from the outside of the deposition chamber;

- $\quad$ it ensures large deposition rates (1-5 $/$ pulse).

However, the pulsed laser deposition technique has also a number of disadvantages, such as:

- $\quad$ the possibility to cover only substrates having small area $\left(\sim 1 \mathrm{~cm}^{2}\right)$;

- the appearance of material droplets or clusters on the surface of the thin films leading to an increased roughness, which can affect the crystallinity, the optical, electrical and magnetic properties of the manufactured thin films $[85,86]$.

The latter disadvantage can be diminished or even eliminated by optimizing the PLD system and deposition conditions as follows:

- the selection of a suitable target material: a target made by dense and very small particles, ensures uniform conditions during the ablation process. A material presenting a lot of defects or different 
structural mechanical strains, which can appear during the processing procedure, affects the deposition process. Moreover, the target material has to present a high absorption coefficient at the used laser wavelength;

- the rotating and the translation of the target material toward the laser beam during the deposition process;

- the optimizing of the deposition parameters (the laser fluence, the laser spot area, the repetition rate);

- the utilization of a supplementary laser beam parallel to the substrate surface which can split the material clusters.

Additionally, the PLD can be coupled with a radiofrequency (RF) plasma source for better performance. Compared to the standard PLD setup, in this case a RF plasma source directed to the substrate is added. The function of the RF source is to ensure a supplementary control of the anionic composition of the manufactured thin films by using gases from the RF plasma source [87]. Figure 6 shows the experimental setup of the RF-assisted PLD vacuum chamber.

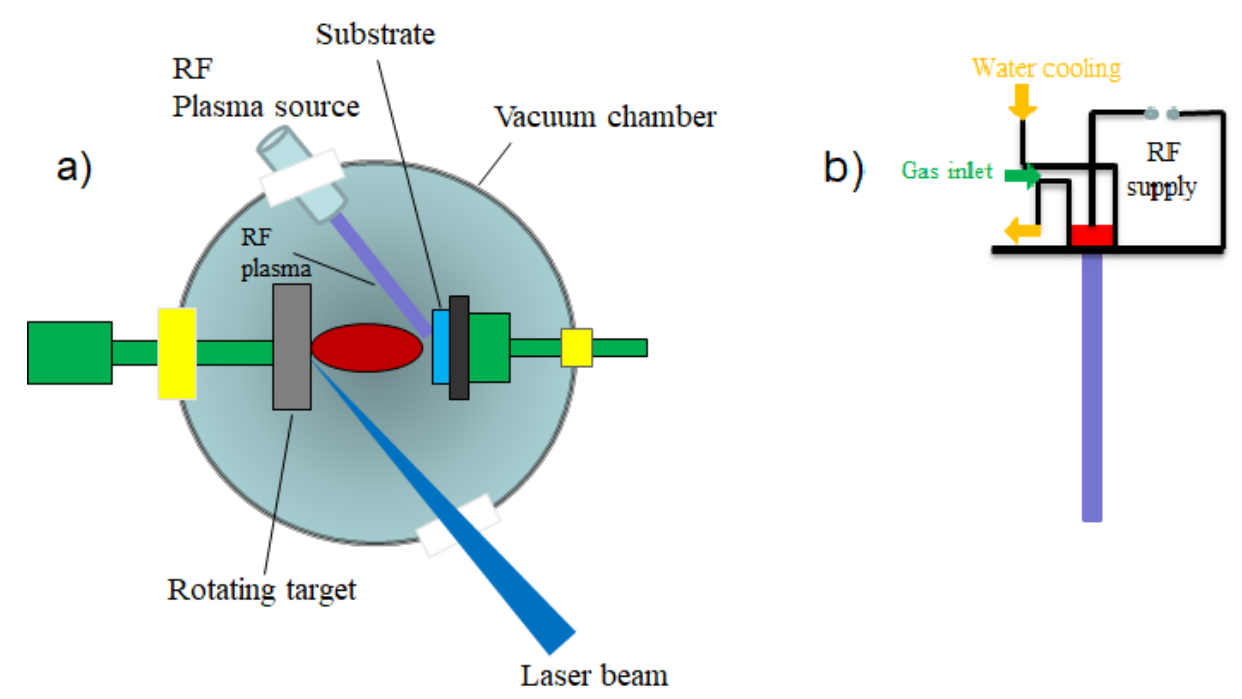

Figure 6. The experimental setup of radiofrequency (RF)-assisted PLD (a) and RF plasma source (b) Adapted from reference [86].

In Table 6 the experimental conditions for different types of perovskite materials grown by PLD and PLD-RF techniques are presented. 
Table 6. Experimental conditions for different types of perovskite materials grown by PLD and PLD-RF techniques and the thickness of the films obtained.

\begin{tabular}{|c|c|c|c|c|c|c|c|}
\hline Perovskite & Support & $\lambda(\mathrm{nm}) / v(\mathrm{~Hz})$ & $\begin{array}{c}\text { Fluence } \\
\left(\mathrm{J} / \mathrm{cm}^{2}\right)\end{array}$ & $\begin{array}{c}\mathrm{P}_{\mathrm{O} 2}{ }^{\mathrm{a}} \\
\text { (mBar) }\end{array}$ & $\begin{array}{l}\mathrm{T}^{\mathrm{b}} \\
\left({ }^{\circ} \mathrm{C}\right)\end{array}$ & $\begin{array}{c}\text { Film Thickness } \\
(\mathrm{nm})\end{array}$ & Ref. \\
\hline $\mathrm{BaTiO}_{3}$ & $\mathrm{MgO}(001)$ & $248 / 10$ & $2-4$ & $4 \times 10^{-3}$ & 1000 & 115 & {$[88,89]$} \\
\hline $\mathrm{BaTiO}_{3}$ & $\mathrm{SrTiO}_{3}(001)$ & $248 / 10$ & $2-4$ & $3 \times 10^{-1}$ & 800 & 115 & {$[88,89]$} \\
\hline $\mathrm{BaTiO}_{3}$ & $\mathrm{SrTiO}_{3}(001)$ & $248 / 10$ & $2-4$ & $2 \times 10^{-3}$ & 800 & 220 & {$[88,89]$} \\
\hline $\mathrm{SrTiO}_{3}$ & $\mathrm{LaAlO}_{3}(100)$ & $248 / 5$ & 1.3 & $1.7 \times 10^{-4}$ & 660 & - & {$[90]$} \\
\hline $\mathrm{BaZrO}_{3}$ & $\mathrm{Si}$ & $193 / 1-3$ & 5.2 & 0.2 & 605 & $1-53$ & [91] \\
\hline $\mathrm{BaZrO}_{3}$ & $\mathrm{SrTiO}_{3}(100)$ & $193 / 1-3$ & 5.2 & 0.2 & 650 & $1-53$ & [91] \\
\hline $\begin{array}{c}\mathrm{Y}_{1-\mathrm{x}} \mathrm{Sr}_{\mathrm{x}} \mathrm{MnO}_{3} \\
(\mathrm{x}=1,0.9,0.8,0.7)\end{array}$ & $\mathrm{SrTiO}_{3}(100)$ & $248 / 3$ & 2 & $0.01-0.13$ & 800 & $0.6-0.65$ & {$[92]$} \\
\hline $\begin{array}{c}\mathrm{Y}_{1-\mathrm{x}} \mathrm{Sr}_{\mathrm{x}} \mathrm{MnO}_{3} \\
(\mathrm{x}=1,0.9,0.8,0.7)\end{array}$ & $\mathrm{LaAlO}_{3}(100)$ & $248 / 3$ & 2 & $0.01-0.13$ & 800 & $0.6-0.65$ & {$[92]$} \\
\hline $\begin{array}{c}\mathrm{Y}_{1-\mathrm{x}} \mathrm{Sr}_{\mathrm{x}} \mathrm{MnO}_{3} \\
(\mathrm{x}=1,0.9,0.8,0.7)\end{array}$ & $\mathrm{NdGaO}_{3}(101)$ & $248 / 3$ & 2 & $0.01-0.13$ & 800 & $0.6-0.65$ & [92] \\
\hline $\mathrm{La}_{0.67} \mathrm{Ca}_{0.33} \mathrm{MnO}_{3}$ & $\mathrm{LaAlO}_{3}$ & $-/ 5$ & n.s. ${ }^{d}$ & 0.26 & $500-700$ & 100 & [93] \\
\hline $\mathrm{La}_{0.67} \mathrm{Ca}_{0.33} \mathrm{MnO}_{3} R F^{\mathrm{c}}$ & $\mathrm{LaAlO}_{3}(100)$ & n.s. & n.s. & Pressure of $0.053\left(60: 40=\mathrm{Ar}: \mathrm{O}_{2}\right.$ or pure $\left.\mathrm{Ar}\right)$ & 850 & n.s. & [93] \\
\hline $\mathrm{La}_{0.67} \mathrm{Ca}_{0.33} \mathrm{MnO}_{3} R F^{\mathrm{c}}$ & $\mathrm{NdGaO}_{3}(110)$ & n.s. & n.s. & Presure of $0.053\left(60: 40=\mathrm{Ar}: \mathrm{O}_{2}\right.$ or pure $\left.\mathrm{Ar}\right)$ & 850 & n.s. & [93] \\
\hline $\mathrm{La}_{0.67} \mathrm{Ca}_{0.33} \mathrm{MnO}_{3}$ & $\mathrm{NdGaO}_{3}$ & $248 / 8$ & $0.2-0.25$ & 0.13 & $600-800$ & 85 & [94] \\
\hline $\mathrm{La}_{0.67} \mathrm{Ca}_{0.33} \mathrm{MnO}_{3} R F^{\mathrm{c}}$ & $\mathrm{SrTiO}_{3}(100)$ & n.s. & n.s. & Presure of $0.053\left(60: 40=\mathrm{Ar}: \mathrm{O}_{2}\right.$ or pure $\left.\mathrm{Ar}\right)$ & 850 & n.s. & [93] \\
\hline $\mathrm{SrFeO}_{3}$ & $\mathrm{SrTiO}_{3}(111)$ & $248 / 2$ & 2.3 & 0.13 & 700 & n.s. & [95] \\
\hline $\begin{array}{l}\mathrm{SrTi}_{1-x} \mathrm{Fe}_{\mathrm{x}} \mathrm{O}_{3-\mathrm{y}} \\
(\mathrm{x}=0.2-0.5)\end{array}$ & Sapphire $\left(\mathrm{Al}_{2} \mathrm{O}_{3}\right)$ & $248 / 8$ & 1.5 & 0.13 & 700 & $200-300$ & [96] \\
\hline $\mathrm{LaNiO}_{3}$ & $\mathrm{SrTiO}_{3}(100)$ & $248 / 5$ & 2 & 0.4 & 825 & 100 & [97] \\
\hline $\mathrm{LaNiO}_{3}$ & $\mathrm{LaAlO}_{3}(100)$ & $248 / 5$ & 1.3 & 0.35 & 660 & n.s. & [90] \\
\hline $\mathrm{Y}\left(\mathrm{Ni}_{0.5} \mathrm{Mn}_{0.5}\right) \mathrm{O}_{3}$ & $\mathrm{SrTiO}_{3}(001)$ & $248 / 2$ & 1.5 & 0.6 & $550-850$ & 70 & [98] \\
\hline $\mathrm{Y}\left(\mathrm{Ni}_{0.5} \mathrm{Mn}_{0.5}\right) \mathrm{O}_{3}$ & $\mathrm{SrTiO}_{3}(110)$ & $248 / 2-20$ & 2 & 0.6 & $550-850$ & 70 & [98] \\
\hline $\mathrm{Y}\left(\mathrm{Ni}_{0.5} \mathrm{Mn}_{0.5}\right) \mathrm{O}_{3}$ & $\mathrm{SrTiO}_{3}(111)$ & $248 / 2-20$ & 2 & 0.6 & $550-850$ & 70 & [98] \\
\hline $\mathrm{Ca}_{0.25} \mathrm{Cu}_{0.75} \mathrm{TiO}_{3}$ & $\mathrm{SrTiO}_{3}(100)$ & $248 / 10$ & 3 & 0.16 & $600-800$ & 250 & [99] \\
\hline $\mathrm{SrRuO}_{3}$ & $\mathrm{SrTiO}_{3}(100)$ & $193 / 1-3$ & 5.2 & 0.2 & $590-650$ & n.s. & [91] \\
\hline $\mathrm{SrRuO}_{3}$ & $\mathrm{SrTiO}_{3}(111)$ & 248 & 2.3 & 0.13 & 700 & n.s. & [95] \\
\hline $\mathrm{PbTiO}_{3}$ & $\mathrm{Si}(100)$ & $248 / 5$ & 8 & $0.13-0.2$ & 530 & 530 & [100] \\
\hline $\mathrm{PbZr}_{0.2} \mathrm{Ti}_{0.8} \mathrm{O}_{3}$ & $\mathrm{SrRuO}_{3} / \mathrm{SrTiO}_{3}(100)$ & $193 / 1-3$ & 5.2 & 0.2 & 587 & n.s. & [91] \\
\hline $\mathrm{Pb}\left(\mathrm{Zr}_{0.45} \mathrm{Ti}_{0.55}\right) \mathrm{O}_{3}$ & $\begin{array}{l}\mathrm{Pb}\left(\mathrm{Zr}_{0.45} \mathrm{Ti}_{0.55}\right) \mathrm{O}_{3} / \mathrm{Pt} / \mathrm{Ti} / \mathrm{SiO}_{2} / \mathrm{Si} \\
\text { prepared by citrate method }\end{array}$ & $248 / 10$ & 1.2 & $1.3 \times 10^{-4}$ & $\mathrm{RT}^{\mathrm{e}}$ & 600 & [101] \\
\hline $\mathrm{BiFeO}_{3}$ & $\mathrm{Pt} / / \mathrm{TiO}_{2} / \mathrm{SiO}_{2} / \mathrm{Si}$ & $355 / 2.5$ & n.s. & 0.07 & 450 & 300 & {$[102,103]$} \\
\hline $\mathrm{BiFeO}_{3}$ & $\mathrm{SrTiO}_{3}(001)$ & $355 / 2.5$ & n.s. & 0.01 & 580 & 70 & {$[102,103]$} \\
\hline $\mathrm{BiFeO}_{3}$ & $\mathrm{Pt}(111) / \mathrm{TiO}_{2} / \mathrm{SiO}_{2} / \mathrm{Si}(100)$ & $248 / 5$ & 2.5 & n.s. & 450 & 230 & [104] \\
\hline $\mathrm{BiFeO}_{3}$ & $\mathrm{SrTiO}_{3}(100)$ & $248 / 5$ & 2 & 0.07 & 750 & 400 & [105] \\
\hline $\mathrm{BiFeO}_{3}$ & $\mathrm{SrRuO}_{3} / \mathrm{SrTiO}_{3}$ & 248 & n.s. & 0.07 & $550-800$ & $280-300$ & [106] \\
\hline $\mathrm{BiFeO}_{3}$ & Nb-doped $\mathrm{SrTiO}_{3}(100)$ & n.s. & n.s. & 0.14 & 650 & 106.5 & {$[107,108]$} \\
\hline $\mathrm{BiFeO}_{3}$ & $\mathrm{SrTiO}_{3}(100)$ & n.s. & n.s. & 0.14 & 650 & 54.3 & {$[107,108]$} \\
\hline $\mathrm{BiFeO}_{3}$ & $\mathrm{DyScO}_{3}(110)$ & n.s. & n.s. & 0.14 & 650 & 34.1 & {$[107,108]$} \\
\hline $\mathrm{BiFeO}_{3}$ & $\mathrm{Nb}$-doped $\mathrm{SrTiO}_{3}(100)$ & $248 / 5$ & n.s. & $0.04-0.4$ & 670 & $30-80$ & [109] \\
\hline $\mathrm{BiFeO}_{3}$ & $\mathrm{Pt} / \mathrm{TiO}_{2} / \mathrm{SiO}_{2} / \mathrm{Si}$ & $248 / 10$ & 2.5 & n.s. & $\mathrm{RT}^{\mathrm{e}}$ & 150 & [110] \\
\hline $\mathrm{BiFeO}_{3}$ & $\mathrm{Nb}$-doped $\mathrm{SrTiO}_{3}(100)$ & 248 & n.s. & 0.02 & 500 & 10 & [111] \\
\hline $\mathrm{BiFeO}_{3}$ & $\mathrm{SrRuO}_{3} / \mathrm{SrTiO}_{3}(001)$ & 248 & n.s. & $0.01-0.26$ & $650-750$ & n.s. & [112] \\
\hline
\end{tabular}


Table 6. Cont.

\begin{tabular}{|c|c|c|c|c|c|c|c|}
\hline Perovskite & Support & $\lambda(\mathrm{nm}) / v(\mathrm{~Hz})$ & $\begin{array}{c}\text { Fluence } \\
\left(\mathrm{J} / \mathrm{cm}^{2}\right)\end{array}$ & $\begin{array}{l}\mathrm{P}_{\mathrm{O} 2}{ }^{\mathrm{a}} \\
\text { (mBar) }\end{array}$ & $\begin{array}{l}\mathrm{T}^{\mathrm{b}} \\
\left({ }^{\circ} \mathrm{C}\right)\end{array}$ & $\begin{array}{c}\text { Film Thickness } \\
(\mathrm{nm})\end{array}$ & Ref. \\
\hline $\mathrm{BiFeO}_{3}$ & $\mathrm{Si}(100)$ & $248 / 5$ & n.s. & n.s. & 670 & $50-100$ & [113] \\
\hline $\mathrm{BiFeO}_{3}$ & $\mathrm{Pt} / \mathrm{TiO}_{2} / \mathrm{SiO}_{2} / \mathrm{Si}$ & $248 / 3$ & 1.5 & 0.53 & 625 & 100 & {$[114,115$} \\
\hline $\mathrm{BiFeO}_{3}$ & $\mathrm{SrRuO}_{3} / \mathrm{SrTiO}_{3}(111)$ & $248 / 3$ & 1.5 & 0.53 & 625 & 100 & {$[114,115$} \\
\hline $\mathrm{BiFeO}_{3}$ & Pt coated $\mathrm{Al}_{2} \mathrm{O}_{3}$ & $248 / 3$ & 1.5 & 0.53 & 625 & 100 & {$[114,115$} \\
\hline$(1-\mathrm{x}) \mathrm{BiFeO}_{3}-\mathrm{xPbTiO}_{3}$ & $\mathrm{PbTiO}_{3} / \mathrm{Pt} / / \mathrm{Ti} / \mathrm{SiO}_{2} / \mathrm{Si}$ & $248 / 5$ & 2.5 & 0.2 & 550 & 230 & [116] \\
\hline $\begin{array}{l}(1-\mathrm{x}) \mathrm{BiFeO}_{3}-\mathrm{xPbTiO}_{3} \\
(\mathrm{x}=0.7,0.8,0.9)\end{array}$ & $\mathrm{Pt} / \mathrm{Ti} / \mathrm{SiO}_{2}$ & $248 / 5$ & 6 & 0.2 & 545 & 400 & [117] \\
\hline $\mathrm{LaCo}_{1-\mathrm{x}} \mathrm{Cr}_{\mathrm{x}} \mathrm{O}_{3}$ & $\mathrm{LaAlO}_{3}(100)$ & $248 / 15$ & n.s. & 0.083 & 650 & $450-530$ & [118] \\
\hline $\mathrm{LaMnO}_{3}$ & $\mathrm{SrTiO}_{3}(001)$ & n.s. & n.s. & 0.013 & 700 & 30 & [119] \\
\hline $\mathrm{LaMnO}_{3}$ & $\mathrm{LaAlO}_{3}(001)$ & $248 / 2$ & n.s. & 0.01 & 700 & $14-90$ & [120] \\
\hline $\mathrm{La}_{0.8} \mathrm{Ca}_{0.2} \mathrm{MnO}_{3}$ & $\mathrm{LaAlO}_{3}(100)$ & $248 / 5$ & 3.2 & 0.4 & 800 & 200 & [121] \\
\hline $\mathrm{La}_{0.7} \mathrm{Sr}_{0.3} \mathrm{MnO}_{3}$ & $\mathrm{Si}(100)$ & $248 / 10$ & n.s. & 0.27 & 650 & 200 & {$[122]$} \\
\hline $\mathrm{La}_{0.67} \mathrm{Sr}_{0.33} \mathrm{MnO}_{3}$ & $\mathrm{LaAlO}_{3}$ & $308 / 5$ & 2 & 0.27 & $500-800$ & 130 & [123] \\
\hline $\mathrm{La}_{0.67} \mathrm{Sr}_{0.33} \mathrm{MnO}_{3}$ & $\mathrm{SrTiO}_{3}$ & $308 / 5$ & 2 & 0.27 & $500-800$ & 130 & [123] \\
\hline $\mathrm{LaFeO}_{3}$ & $\mathrm{SrTiO}_{3}(100)$ & $248 / 4$ & 1.9 & 0.4 & 670 & $25-35$ & [124] \\
\hline $\mathrm{LaFeO}_{3}$ & $\mathrm{GdScO}_{3}(110)$ & 248 & 1 & 0.13 & 700 & 100 & [125] \\
\hline $\mathrm{LaFeO}_{3}$ & $\mathrm{SrTiO}_{3}(100)$ & $248 / 4$ & 2.4 & 0.2 & 670 & 54 & [126] \\
\hline $\mathrm{LaFeO}_{3}$ & $\mathrm{SrTiO}_{3}(100)$ & $248 / 5$ & 5.5 & 0.07 & 800 & 400 & [127] \\
\hline $\mathrm{LaFeO}_{3}$ & $\mathrm{Nb}$-doped $\mathrm{SrTiO}_{3}$ & $193 / 5$ & 2.2 & $0.05-0.9$ & 750 & n.s. & [128] \\
\hline $\mathrm{LaFeO}_{3}$ & $\mathrm{SrTiO}_{3}(100)$ & $248 / 10$ & 0.2 & $4 \times 10^{-5}$ & 700 & 65 & [129] \\
\hline $\mathrm{LaFeO}_{3}$ & $\mathrm{LaAlO}_{3}(100)$ & $248 / 10$ & 0.2 & $4 \times 10^{-5}$ & 700 & 65 & [129] \\
\hline $\mathrm{La}_{1-\mathrm{x}} \mathrm{Sr}_{x} \mathrm{CoO}_{3}$ & Si (001) & $266 / 10$ & 2 & 0.05 & 740 & 120 & [130] \\
\hline $\mathrm{La}_{1-\mathrm{x}} \mathrm{Sr}_{x} \mathrm{CoO}_{3}$ & $\mathrm{MgO}(001)$ & $266 / 10$ & 2 & 0.05 & 740 & 120 & [130] \\
\hline $\begin{array}{l}\mathrm{La}_{1-\mathrm{x}} \mathrm{Sr}_{\mathrm{x}} \mathrm{CoO}_{3} \\
(\mathrm{x}=0,0.1,0.2)\end{array}$ & $\mathrm{Si}(100)$ & $248 / 10$ & 2 & 0.13 & 600 & n.s. & {$[131]$} \\
\hline $\begin{array}{l}\mathrm{La}_{1-\mathrm{x}} \mathrm{Sr}_{\mathrm{x}} \mathrm{CoO}_{3} \\
(\mathrm{x}=0,0.1,0.2)\end{array}$ & $\mathrm{Si}(100)$ & $266 / 10$ & 2 & 0.05 & 660 & 100 & [132] \\
\hline $\begin{array}{l}\mathrm{Sr}_{1-x} \mathrm{La}_{x} \mathrm{Ru}_{1-x} \mathrm{Fe}_{x} \mathrm{O}_{3} \\
(\mathrm{x}=0.05,0.1,0.2,0.3)\end{array}$ & $\mathrm{SrTiO}_{3}(100)$ & $248 / 4$ & 2.5 & $0.2-0.33$ & 750 & 60 & [133] \\
\hline $\mathrm{Bi}_{0.9} \mathrm{La}_{0.1} \mathrm{Fe}_{0.95} \mathrm{Mn}_{0.05} \mathrm{O}_{3}$ & $\mathrm{Pt}(111) / \mathrm{Ti} / \mathrm{SiO} / \mathrm{Si}$ & 248 & 1.5 & $7 \times 10^{-3}$ & $450-650$ & 250 & [134] \\
\hline $\begin{array}{l}\left(\mathrm{Bi}_{1-\mathrm{x}} \mathrm{La}_{\mathrm{x}}\right)\left(\mathrm{Fe}_{1-\mathrm{x}} \mathrm{Al}_{\mathrm{x}}\right) \mathrm{O}_{3} \\
(\mathrm{x}=0,0.1,0.2,0.3,0.4)\end{array}$ & $\mathrm{Nb}$-doped $\mathrm{SrTiO}_{3}(001)$ & 266 & n.s. & 0.065 & 600 & n.s. & [135] \\
\hline $\mathrm{La}_{0.8} \mathrm{Ce}_{0.2} \mathrm{MnO}_{3}$ & $\mathrm{LaAlO}_{3}(001)$ & $248 / 8$ & 2 & 0.4 & 800 & 150 & [136] \\
\hline $\begin{array}{c}\mathrm{Bi}_{1-x} \mathrm{Pr}_{x} \mathrm{FeO}_{3} \\
(\mathrm{x}=0,0.05,0.1,0.15)\end{array}$ & $\mathrm{Pt} / \mathrm{SiO}_{2}$ & $355 / 5$ & 2.5 & n.s. & 450 & 200 & [137] \\
\hline $\mathrm{NdNiO}_{3}$ & $\mathrm{MgO}(100)$ & $248 / 10$ & 1.5 & 0.15 & 675 & 500 & [138] \\
\hline $\mathrm{NdNiO}_{3}$ & $\mathrm{SrTiO}_{3}(100)$ & $248 / 10$ & 1.5 & 0.15 & 675 & 500 & {$[138]$} \\
\hline $\mathrm{NdNiO}_{3}$ & $\mathrm{NdGaO}_{3}(110)$ & $248 / 10$ & 1.5 & 0.15 & 675 & 500 & [138] \\
\hline $\mathrm{NdNiO3}$ & $\mathrm{NdGaO}_{3}(001)$ & $-/ 10$ & 1.9 & 3 & 900 & $30-50$ & [139] \\
\hline $\mathrm{Bi}_{0.9} \mathrm{Sm}_{0.1} \mathrm{Fe}_{0.95} \mathrm{Co}_{0.05} \mathrm{O}_{3}$ & $\mathrm{Pt} / \mathrm{TiO}_{2} / \mathrm{SiO}_{2} / \mathrm{Si}$ & $248 / 10$ & $2-5$ & 0.13 & $700-750$ & $300-360$ & [140] \\
\hline $\mathrm{Bi}_{0.9} \mathrm{Sm}_{0.1} \mathrm{Fe}_{0.95} \mathrm{Co}_{0.05} \mathrm{O}_{3}$ & $\mathrm{Pt} / \mathrm{TiO}_{2} / \mathrm{SiO}_{2} / \mathrm{Si}$ & $248 / 10$ & $2-5$ & 0.13 & $700-750$ & $300-360$ & [140] \\
\hline $\begin{array}{c}\mathrm{Bi}_{1-\mathrm{x}} \mathrm{Sm}_{\mathrm{x}} \mathrm{FeO}_{3}(\mathrm{x}=0.05 \\
0.1,0.12,0.14,0.16)\end{array}$ & $\mathrm{Pt}(111) / \mathrm{SiO}_{2}$ & $355 / 5$ & n.s. & 0.04 & 450 & 200 & [141] \\
\hline $\mathrm{TmMnO}_{3}$ & $\mathrm{SrTiO}_{3}(110)$ & 248 & n.s. & 0.1 & 940 & 20 & [142] \\
\hline
\end{tabular}

${ }^{a} \mathrm{P}_{\mathrm{O} 2}$-the oxygen pressure during the deposition process; ${ }^{\mathrm{b}} \mathrm{T}$ - the substrate temperature during the deposition process; ${ }^{\mathrm{c}} R F-$ prepared via PLD-RF; $^{\mathrm{d}}$ n.s. - not specified; ${ }^{\text {e }} \mathrm{RT}$-room temperature. 


\subsubsection{Matrix-Assisted Pulsed Laser Evaporation (MAPLE)}

A major disadvantage of the manufacturing of thin films by laser ablation arises from the deposition process. The plasma formation and the condensation of elements on a substrate are not suitable for soft organic and polymeric materials, because their structure can be decomposed easily or even completely destroyed as an effect of interaction with laser beam. In order to depose this kind of materials, a modification of the experimental setup is required, this modification being related to the deposition target. Therefore, in the matrix-assisted pulsed laser evaporation (MAPLE) technique the target is prepared by dissolving the polymeric (or organic) material into a volatile solvent and the resulting mixture is frozen in liquid nitrogen. A photograph of a MAPLE target can be seen in Figure 7 . The laser wavelength is selected in such a way that only the solvent reacts when the laser beam hits the frozen target $[143,144]$.

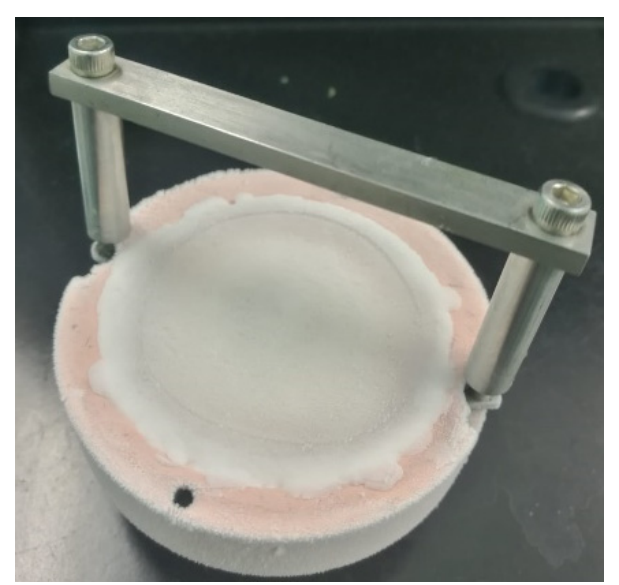

Figure 7. Photographs of frozen material used as matrix-assisted pulsed laser evaporation (MAPLE) target.

The difference between this technique and PLD lays in the target preparation, which generates other laser-material interaction mechanisms [145]. The setup used for MAPLE deposition is presented in Figure 8.

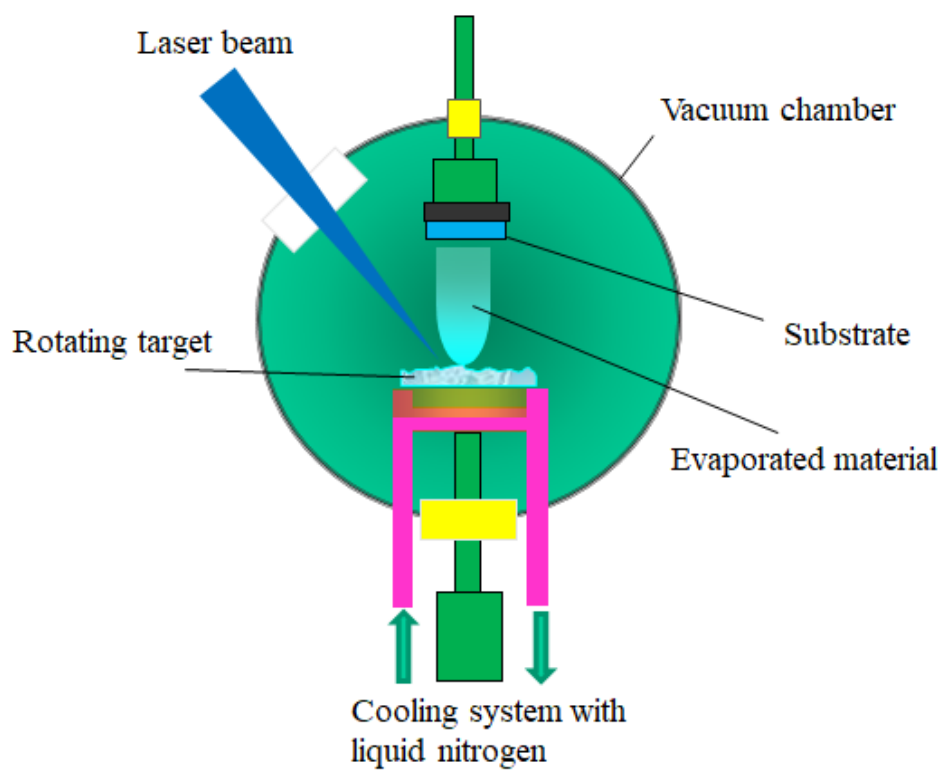

Figure 8. The schematic setup of the MAPLE technique. Adapted from reference [86]. 
In this case, two main processes occur when the laser beam falls onto the target surface: the evaporation of the frozen target and the ejection of the organic material. Generally, the concentration of polymeric (or organic) substance is very low (ca. 1-5\%), the evaporation of the solvent and of the desired substance taking place simultaneously. The energy of the photons absorbed by the solvents is converted into thermal energy which induces the heating and the evaporation of the target. The polymeric chains have sufficient kinetic energy to cross the distance between the target and the substrate, while the solvent molecules are eliminated from the reaction chamber by the vacuum pumps. When the experimental conditions are optimized, the polymeric (or organic) substances can be transferred from the target to the substrate without structural damage $[146,147]$. This method has also been used to obtain some perovskite thin films (Table 7).

Table 7. Perovskites prepared by MAPLE.

\begin{tabular}{|c|c|c|c|c|c|c|c|}
\hline Material & Target Concentration & Substrate & $\begin{array}{l}\lambda(\mathrm{nm}) / \\
v(\mathrm{~Hz})\end{array}$ & Fluence $\left(\mathrm{J} / \mathrm{cm}^{2}\right)$ & $\mathbf{P}_{\mathrm{N} 2}$ (mbar) & $\mathrm{D}_{\mathrm{T}-\mathrm{S}}(\mathrm{cm})$ & Ref. \\
\hline $\mathrm{rGO} / \mathrm{BiFeO}_{3}$ & $\begin{array}{c}3 \text { wt. } \% \mathrm{BiFeO}_{3} \\
5 \text { wt. } \% \mathrm{GO}\end{array}$ & $\begin{array}{l}\text { F-doped } \\
\mathrm{SnO}_{2}\end{array}$ & $266 / 10$ & 0.4 & 0.2 & 4 & [148] \\
\hline $\mathrm{rGO} / \mathrm{LaFeO}_{3}$ & $\begin{array}{c}3 \text { wt. } \% \mathrm{LaFeO}_{3} \\
5 \text { wt. } \% \mathrm{GO}\end{array}$ & $\begin{array}{l}\text { F-doped } \\
\mathrm{SnO}_{2}\end{array}$ & $266 / 10$ & 0.4 & 0.2 & 4 & [148] \\
\hline $\mathrm{CH}_{3} \mathrm{NH}_{3} \mathrm{PbI}_{3}$ & $\mathrm{PbI}_{2}: \mathrm{MAI}=1: 3$ & ITO & $\mathrm{IR} / 2$ & $0.125-0.135$ & $1 \times 10^{-3}$ & 7 & [149] \\
\hline $\mathrm{CH}_{3} \mathrm{NH}_{3} \mathrm{PbI}_{3}$ & $\begin{array}{l}\mathrm{PbI}_{2}: \mathrm{MAI}=1: 1 \text { in } \\
\text { DMSO and MEG }\end{array}$ & $\mathrm{FTO} / \mathrm{NiO}_{\mathrm{x}}$ & - & - & - & - & [150] \\
\hline
\end{tabular}

Abbreviations: $\mathrm{D}_{\mathrm{T}-\mathrm{S}}$ - the distance between the material target and the substrate; $\mathrm{rGO}$-reduced graphene oxide; MAI—-methylammonium iodide; ITO—indium tin oxide; IR—infrared radiation; DMSO—dimethyl sulfoxide; MEG—ethylene glycol; FTO—fluorine-doped tin oxide.

\section{Catalytic Applications of Perovskite-Type Materials}

\subsection{Energy Production}

Nowadays, one of the major problems facing humanity is to fully cover the global energy demands which have severely increased in the last few years. Most energy is generated by using fossil fuels. The high energy demand on the market accelerates the consumption of these exhaustible resources based on carbon. Moreover, the intense utilization of fossil fuels causes the greenhouse effect and generates huge amounts of pollutants affecting the environmental safety and human's health [151]. Hence, a new alternative for energy production must be urgently and efficiently implemented. One of the most promising ways to solve the current energy problem is to use solar energy. The energy provided by the sun is abundant, among the cleanest energy resources, which does not make the global warming status worse. Furthermore, solar energy is an ecological and renewable source, and these features are propelling it as a suitable candidate for the global supply. Solar energy can be converted to both electrical and chemical energies by using photovoltaic and photocatalytic concepts. However, until technologies based on these processes are suitable for industrial implementation, new alternatives in order to increase fossil fuels' efficiency and to minimize the pollution are required. Among others, catalytic combustion of methane is one of the promising ways to increase the efficiency and to minimize pollution [152].

\subsubsection{The Production of Energy in the Form of Hydrogen via Water Photodecomposition}

Hydrogen is considered to be one of the most suitable options to replace the carbon-based fuels. It can be generated using different methods from various renewables (hydro, solar) and non-renewables (coal, natural gas, nuclear) sources. Among these, hydrogen can be produced from water through different processes, such as high-temperature decomposition (thermochemical water splitting) [153-155], electrolysis [156], photocatalysis [157] and photoelectrochemical water splitting [158]. Today, hydrogen is mainly synthesized by steam reforming of hydrocarbons (especially methane). It finds uses generally in petroleum refining [159], the production of ammonia [160] and in the metal refining industry [161]. For the future, it is intended to use hydrogen in fuel cells for high-efficiency power production systems 
which can directly produce electricity at low temperatures, with no emission of toxic by-products. In practice, inside a fuel cell, the hydrogen or a hydrogen-rich fuel is reacting with pure oxygen or oxygen from air, the resulting product being water [162]. As already discussed in Section 4.1, the solar energy is considered the most suitable alternative as global energy supplier and thus the water photodecomposition reaction is one of the most studied methods for chemical energy (hydrogen) production.

There are two similar processes for the photodecomposition of water: photocatalysis, which is based on a particulate system, and photoelectrocatalysis (also known as photoelectrochemistry) based on photoelectrochemical (PEC) cells. A schematic representation of the mechanisms involved in these two processes can be found in Figure 9 .

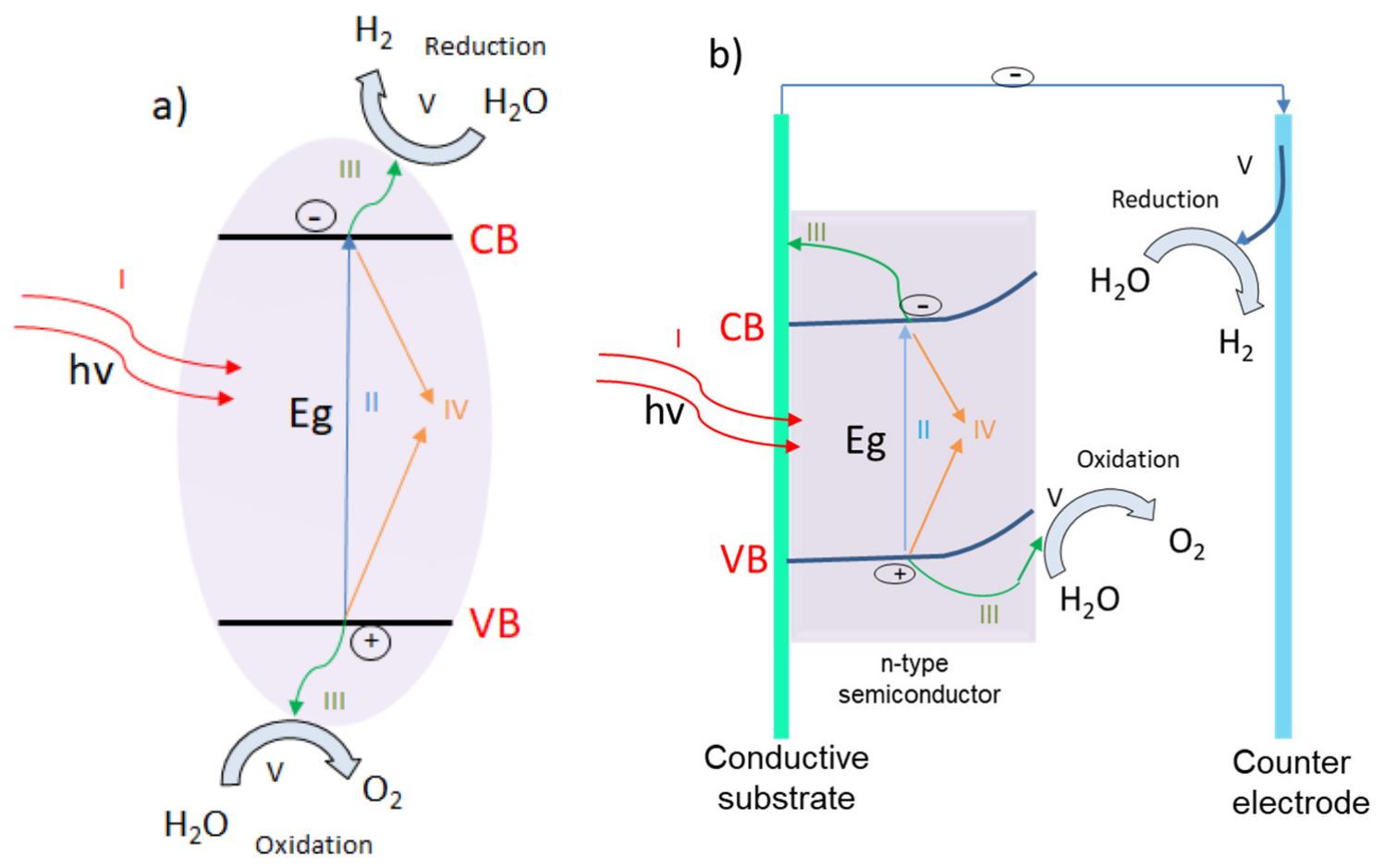

Figure 9. Schematic illustration of (a) photocatalytic (PC-I. Light absorption; II. Electrons jump from the valence band (VB) to the conduction band (CB); III. Redox processes; IV. Bulk recombinations) and (b) photoelectrochemical (PEC-I. Light absorption; II. Electrons jump from VB to CB; III. Transfer of charge carriers to the electrodes surface; IV. Bulk recombinations; V. Redox processes) processes Adapted from Ref [163].

Generally, in photocatalysis, the photocatalyst powders are freely suspended in a solution (as a slurry) or are fixed in a reactor bed. This is considered one of the most simple and cheapest methods for water photodecompositon which does not require transparent electrodes or directional illumination. As can be observed from Figure 9, the semiconductor photocatalyst particles are irradiated and the photons having energies higher than the material band gap are absorbed. The photons' absorption is followed by the charge carriers formation, electrons $\left(\mathrm{e}^{-}\right)$are excited to the conduction band (CB), positive holes $\left(\mathrm{h}^{+}\right)$being simultaneously created in the valence band (VB). Once formed, the charge carriers migrate to the photocatalyst surface. When they arrive to the solid photocatalyst/liquid electrolyte interface, electrons are reducing water to molecular $\mathrm{H}_{2}$, while positive holes are oxidizing it to $\mathrm{O}_{2}$. Unfortunately, only a small portion of the photogenerated charge carriers participate in the redox reaction, and most of them suffer bulk or surface recombination, as can be seen in Figure 10 . In fact, the charge recombination is one of the biggest challenges of this type of process, because a high loss of the excited charge carriers leads to a decrease in the reaction yield [164,165]. 


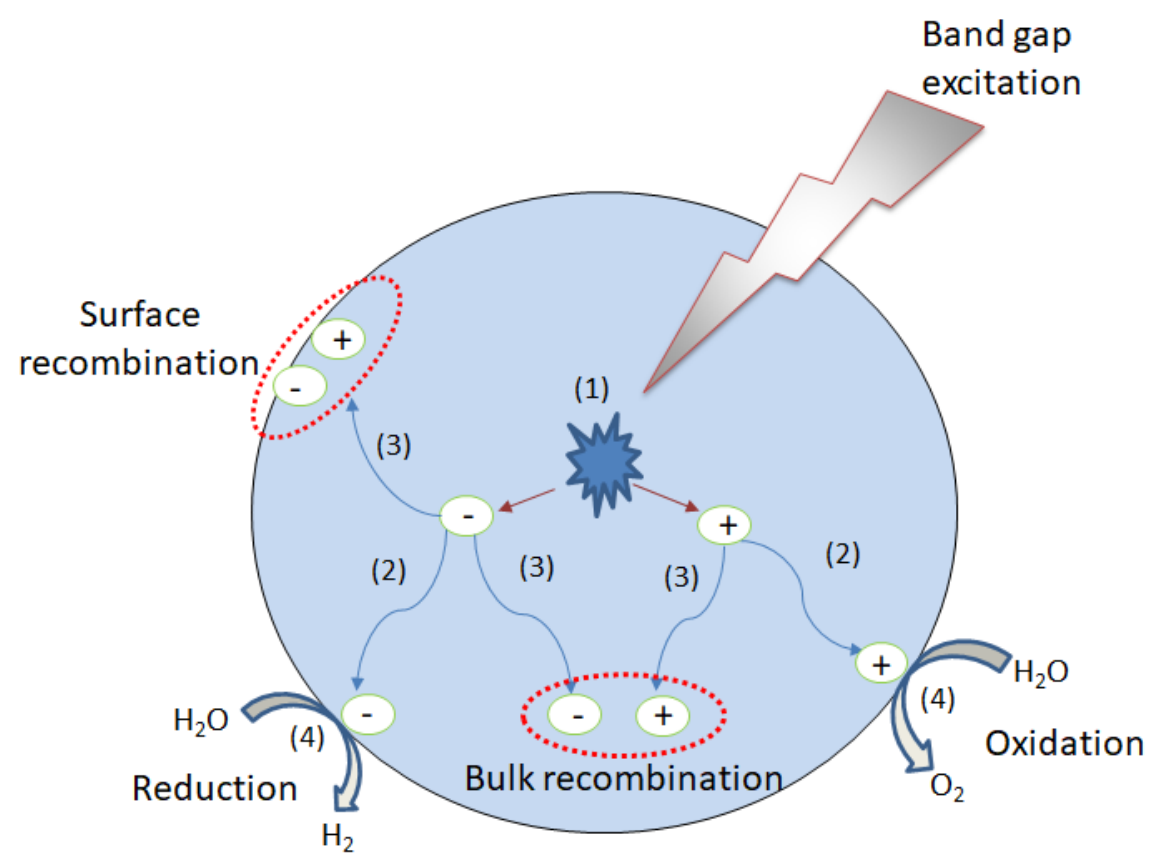

Figure 10. Schematic diagram of the charge carriers formation in a photocatalytic process. Adapted from reference [165].

In order to evaluate the performance of a photocatalyst, the concept of the apparent quantum yield (QE \%) was introduced and it is described by the following formulae [166,167]:

$$
\begin{gathered}
\text { QE } \left.(\%)=\left(2 \times \text { number of } \mathrm{H}_{2} \text { molecules/number of incident photons }\right) \times 100 \text { (for hydrogen }\right) \\
\text { QE } \left.(\%)=\left(4 \times \text { number of } \mathrm{O}_{2} \text { molecules/number of incident photons }\right) \times 100 \text { (for oxygen }\right)
\end{gathered}
$$

In addition to the high recombination of the photogenerated charge carriers, the photocatalytic system has other major disadvantages. The photogenerated hydrogen and oxygen gas are formed on the same photocatalyst surface and, hence, they are predisposed to form water via the so-called "surface back-reaction" (SBR). In order to avoid this reaction, the photocatalytic systems require the utilization of additional sacrificial reagents which are electron acceptors or donors. Moreover, the final separation of the gas produced requires additional energy consumption. Also, because the solid particles are suspended in the liquid electrolyte, a part of irradiation light will be absorbed by the liquid medium, decreasing the energy of incident light which interacts with the photocatalyst [167].

On the other hand, in a PEC system the standard configuration is based on a photoelectrode (called working electrode) and a counter electrode, as presented on Figure 9. The working electrode consists of a semiconductor material (of either n-type or p-type) deposited on a conductive substrate. When the semiconductor material is of n-type, the working electrode acts as photoanode (Figure 11a), while when it is of p-type, it operates as photocathode (Figure 11b). Moreover, the PEC system can also work as a tandem system with both photoanode and photocathode, as shown in Figure 11c. 
(a)

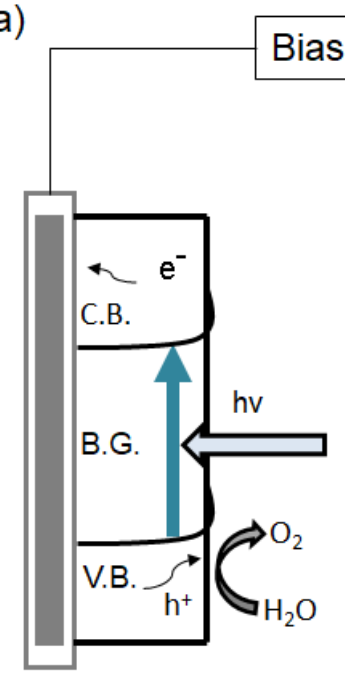

n-type semiconductor electrode (b)

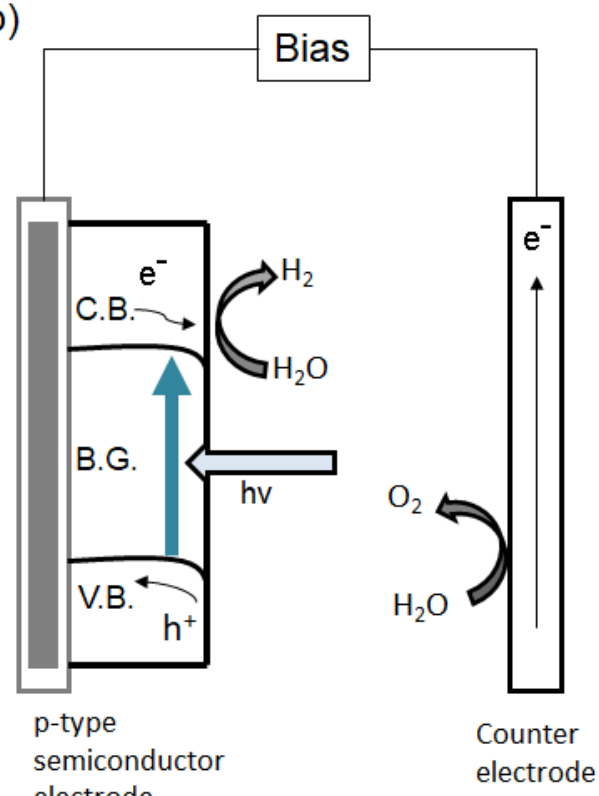

Counter electrode

(c)

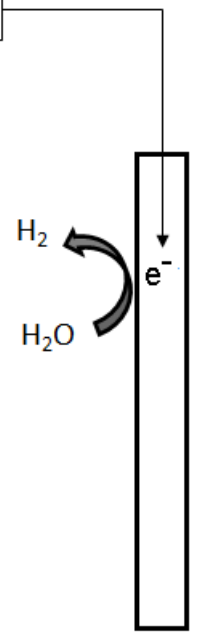

Counter electrode

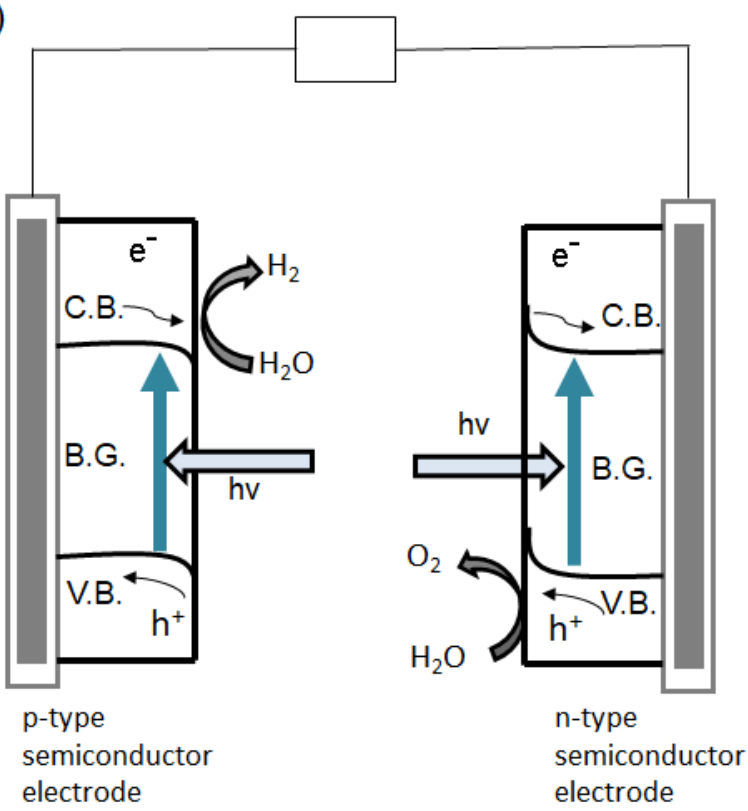

Figure 11. Photoelectrochemical water-splitting systems with: (a) n-type semiconductor photoanode; (b) p-type semiconductor photocathode; (c) tandem system. Adapted from reference [163].

For example, in a standard PEC configuration, when photons are absorbed by a n-type semiconductor, the positive holes from the valance band are migrating to the photoelectrode surface, where water is oxidized to $\mathrm{O}_{2}$. The electrons are collected by the conductive substrate and they are sent through an external circuit to the counter electrode $(\mathrm{Pt})$, where water molecules are reduced to $\mathrm{H}_{2}$. Generally, in order to ensure a better separation of the charge carriers, an external electrical or chemical ( $\mathrm{pH}$ difference) bias between electrodes is applied. When the working electrode is made of p-type semiconductor, $\mathrm{O}_{2}$ is formed at the counter electrode surface, while $\mathrm{H}_{2}$ is generated on the p-type photoanode surface. Also, the same principle is applied for tandem PEC configuration, water molecules are reduced to $\mathrm{H}_{2}$ at the p-type semiconductor surface while being oxidized to $\mathrm{O}_{2}$ at the surface of the n-type semiconductor [163].

The PEC system shows excellent advantages compared to the particulate system, the oxygen is generated at the photoanode, while the hydrogen is formed at the photocathode. In this way, 
the resulting gas can be independently collected with no further costly gas separation methods or efficiency lowering because of SBR. Furthermore, appropriate and superior quality contact between the conductive substrate and semiconductor ensures excellent charge transfer leading to great photoelectrochemical efficiencies [168].

The PEC water-splitting processes can be divided into two electrochemical redox reactions: the hydrogen evolution reaction (HER) and the oxygen evolution reaction (OER). The HER can occur by the Volmer-Heyrowsky or Volmer-Tafel mechanisms following a two-electron transfer process $\left(2 \mathrm{H}_{2} \mathrm{O}+2 \mathrm{e}^{-} \rightleftarrows \mathrm{H}_{2}+2 \mathrm{HO}^{-}\right)$[169]. On the other hand, the OER is a more complicated redox process implying the transfer of four electrons $\left(2 \mathrm{H}_{2} \mathrm{O} \rightleftarrows 4 \mathrm{e}^{-}+\mathrm{O}_{2}+4 \mathrm{H}^{+}\right)[170,171]$. Depending on the experimental conditions, as well as, the nature and the physico-chemical properties of the photoelectrodes, the backward reactions can affect the global water splitting efficiency. The hydrogen oxidation reaction (HOR) is based on the oxidation at the cathode of $\mathrm{H}_{2}$ to $\mathrm{H}^{+}$by the same mechanism as HER. By contrast, at the anode, the oxygen reduction reaction (ORR) can directly or indirectly occur by the same four-electron transfer process. The direct reduction of $\mathrm{O}_{2}$ leads to $\mathrm{H}_{2} \mathrm{O}$ formation, and it can be associative or dissociative. On the other hand, the indirect process leads to water formation from intermediate compounds such as hydrogen peroxide [172,173]. The dissociation of $\mathrm{H}_{2} \mathrm{O}$ molecule into $\mathrm{H}_{2}$ and $\frac{1}{2} \mathrm{O}_{2}$ is a thermodynamically non-spontaneous reaction and, hence, in order to occur, it requires an excess of energy corresponding to a Gibbs free energy of $+237 \mathrm{~kJ} / \mathrm{mol} \mathrm{H}_{2}$ (1.23 eV/electron transfer). In other words, the water photo-dissociation can theoretically occur only if the absorbed photons have energies higher than $1.23 \mathrm{eV}$, which correspond to $1100 \mathrm{~nm}$. As can be seen, the infrared light is the most suitable for water photodecompositon reaction, at least from a theoretical point of view. Nevertheless, in practice a higher energy is required because of the energy losses (electron/hole transfer, the recombination of electron/hole, kinetic losses). Generally, it is recommended to use photocatalysts/photoelectrodes having a band gap value of $2.0-2.2 \mathrm{eV}$ to overcome losses. Another important factor for the overall efficiency of water splitting reaction is related to the energy position of the bands extrema. In order to make possible the HER the bottom of the conduction band (CB) of the photocatalyst must be located at a potential which is more negative than the reduction potential of $\mathrm{H}^{+} / \mathrm{H}_{2}(0 \mathrm{~V}$ vs. NHE-normal hydrogen electrode) and the top of the valence band (VB) has to be located at more positive potential than the oxidation potential of $\mathrm{H}_{2} \mathrm{O} / \mathrm{O}_{2}(1.23 \mathrm{~V}$ vs. NHE) [174]. A schematic representation is presented in Figure 12.

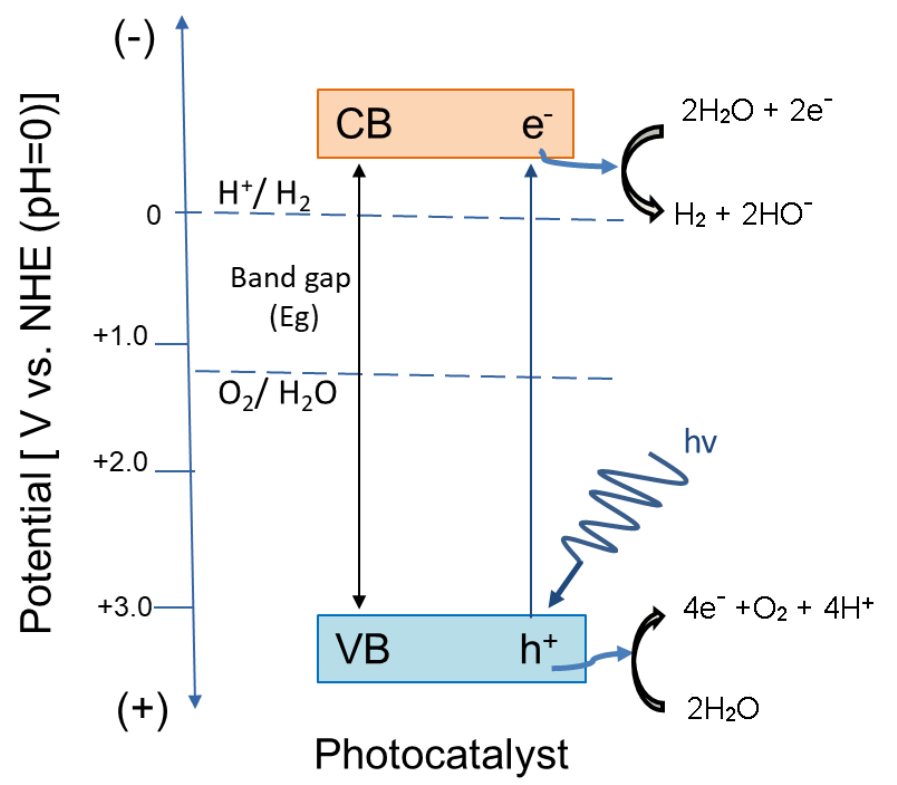

Figure 12. The ideal VB and CB positions for water splitting reaction. Adapted from reference [168]. 
In order to evaluate the performance and efficiency of materials and devices used in PEC systems, it is required to use benchmark metrics of assessment. One of the most important methods for the performance quantification of PEC systems is a photocurrent density-voltage (J-V) curve. This technique implies the measurement of the photocurrent density $\left(\mathrm{mA} / \mathrm{cm}^{2}\right)$ as a function of the applied voltage $(\mathrm{V})$ under chopped or continuous irradiation. The presence of the anodic photocurrent is correlated to the $\mathrm{O}_{2}$ generation, while the cathodic photocurrent with $\mathrm{H}_{2}$ generation, respectively. Figure 13 displays the J-V curves for a photoanode in dark with/without catalyst and under illumination with/without catalyst [175]. The onset potential is defined as the applied potential where the current starts to increase; a lower onset potential is desired from an economical energy consumption point of view.

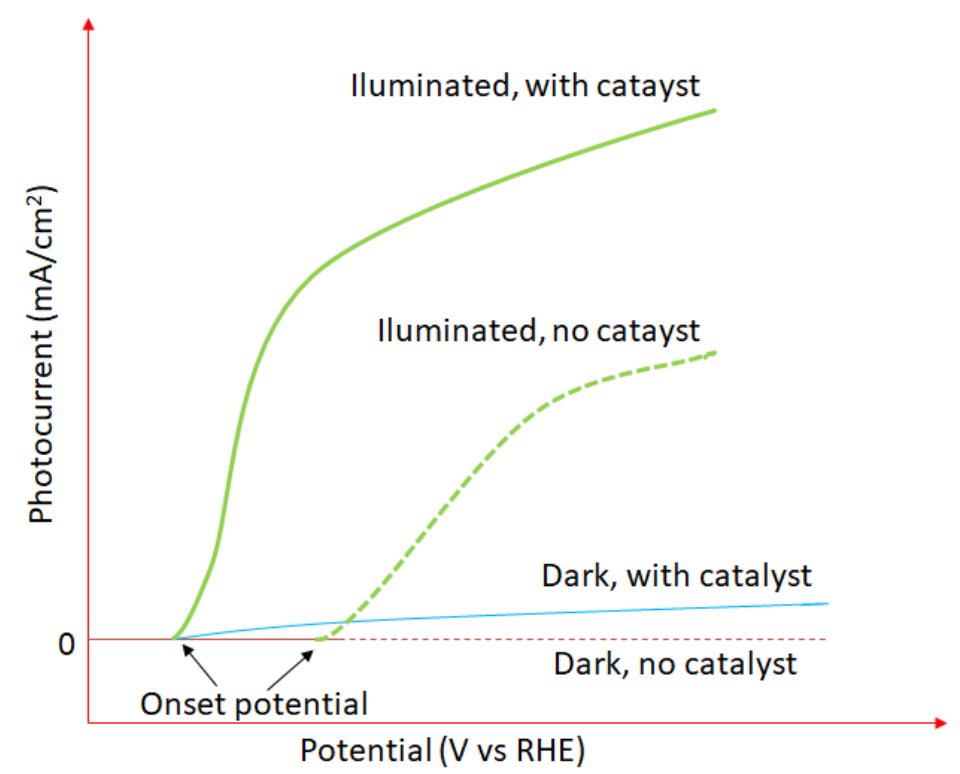

Figure 13. J vs. V curves for a photoanode in dark and illumination in the presence/absence of a photocatalyst. Adapted from reference [175].

Alternatively, a direct correlation between solar energy and hydrogen evolution is necessary to calculate the solar to hydrogen (STH) efficiency. In order to determine this efficiency, it is necessary to quantitatively measure the produced $\mathrm{H}_{2}$. STH efficiency gives the overall reaction efficiency of a PEC system used for water splitting reaction under simulated solar illumination and with no external voltage applied. Also, it can be calculated only if the electrodes are immersed in the same electrolyte without other sacrificial reagents [176]. STH efficiency can be calculated using the following formula:

$$
\mathrm{STH}=\left(\frac{\mathrm{v}_{\mathrm{H}^{2}}\left(\frac{\mathrm{mmol}}{\mathrm{s}}\right) \times 237,000\left(\frac{\mathrm{mj}}{\mathrm{mmol}}\right)}{\mathrm{P}_{\text {light }}\left(\frac{\mathrm{mW}}{\mathrm{cm}^{2}}\right) \times \mathrm{A}\left(\mathrm{cm}^{2}\right)}\right) \text { AM1.5G }
$$

where, $v_{\mathrm{H} 2}$ is the number of $\mathrm{mmol}$ of photogenerated $\mathrm{H}_{2}, 237,000 \mathrm{~mJ} / \mathrm{mmol}$ represent the Gibbs free energy, $\mathrm{P}_{\text {light }}$ is the power density of the incident light and $\mathrm{A}$ is the illuminated area of the electrode (area of the spot light). AM 1.5G (air mass 1.5 G) represents the standard reference solar spectra used to calculate the conversion efficiency of solar energy to electrical or chemical energy. It defines the effect produced by the atmosphere of the Earth on the solar radiation [177].

Also, STH efficiency can be directly calculated from the photocurrent density when the measurement of the $\mathrm{H}_{2}$ amount is not possible, using the formula [178]:

$$
\mathrm{STH}=\left(\frac{\mathrm{J}_{\mathrm{ph}}\left(\frac{\mathrm{mA}}{\mathrm{cm}^{2}}\right) \times \mathrm{V}_{\text {redox }} \times \eta_{\mathrm{f}}}{\mathrm{P}_{\text {light }}\left(\frac{\mathrm{mW}}{\mathrm{cm}^{2}}\right)}\right) \text { AM1.5G }
$$


where, $\mathrm{J}_{\mathrm{ph}}$ is the photogenerated current density, $\mathrm{V}_{\text {redox }}$ is the redox potential of interest $(1.23 \mathrm{~V})$ and $\eta_{\mathrm{f}}$ is the faradaic efficiency of the hydrogen evolution reaction.

For the determination of the faradaic efficiency of hydrogen, it is crucial to know the active surface area of the catalyst (photoelectrode) and the current density passing between the two electrodes [178].

For the system where an external bias is applied, other tools are required for the calculation of the efficiency. One of them is the applied bias photon-to-current conversion efficiency (ABPE) calculated with the following formula:

$$
\mathrm{ABPE}=\left(\frac{\mathrm{J}_{\mathrm{ph}}\left(\frac{\mathrm{mA}}{\mathrm{cm}^{2}}\right) \times \mathrm{V}_{\text {redox }}-\mathrm{V}_{\text {applied }} \times \eta_{\mathrm{f}}}{\mathrm{P}_{\text {light }}\left(\frac{\mathrm{mW}}{\mathrm{cm}^{2}}\right)}\right) \text { AM1.5G }
$$

where $V_{\text {applied }}$ is the potential applied between the working and counter electrodes.

This formula can be applied for PEC devices working in a three-electrode system which implies the addition of a reference electrode. As in the case of STH efficiency, for the calculation of ABPE efficiency the utilization of sacrificial reagents and chemical bias should be avoided [176].

In addition, the incident photon-to-current efficiency (IPCE) is one of the most important tools for the evaluation of PEC performances. It offers the possibility to determine the practical efficiency limits of a material that can be used in PEC systems. It can be determined using the following formula [176]:

$$
\mathrm{IPCE}=\left(\frac{\mathrm{J}_{\mathrm{ph}}\left(\frac{\mathrm{mA}}{\mathrm{cm}^{2}}\right) \times 1239.8(\mathrm{~V} \times \mathrm{nm})}{\mathrm{P}_{\mathrm{mono}}\left(\frac{\mathrm{mW}}{\mathrm{cm}^{2}}\right) \times \lambda(\mathrm{nm})}\right)
$$

where $1239.8(\mathrm{~V} \times \mathrm{nm})$ represents a multiplication of $\mathrm{h}$ (Planck's constant) and $\mathrm{c}$ (the speed of light), $\mathrm{P}_{\text {mono }}$ is the power density of the monochromated light used for photoelectrode irradiation and $\lambda$ is the wavelength of the light.

In 1972, Fujishima et al. reported the first photoelectrochemical water splitting reaction with solar hydrogen production opening new opportunities in the PEC field [179]. The authors used n-type $\mathrm{TiO}_{2}$ as photoanode and an irradiation source emitting in the ultraviolet (UV) region. Since Fujishima and Honda discovered this effect, $\mathrm{TiO}_{2}$ has been extensively used as photoelectrode because it is cheap, non-toxic and possesses high photostability. However, it has a wide band gap (ca. $3.2 \mathrm{eV} ; \lambda \approx 396 \mathrm{~nm}$ ) and it can absorb only the UV light which represents a small part of solar light $(3-5 \%)[180,181]$.

Taking into account the excellent efficiencies of HOIPs in the photovoltaic applications, they seem to be possible candidates for integration in PEC devices. In a PEC system, the photoelectrodes must be in direct contact with an aqueous solution of electrolyte in order for the chemical reaction to take place. As already mentioned, the organic perovskites are very unstable in aqueous media, hence the presence of moisture has crucially affected their application in photoelectrochemistry $[182,183]$. However, many researchers have tried to overcome this drawback in order to generate a device showing excellent stability and high efficiency for PEC water splitting applications. The passivation of $\mathrm{CH}_{3} \mathrm{NH}_{3} \mathrm{PbI}_{3}$-based photoanode with a very thin Ni layer for both waterproof coating and the holes transfer has been reported. The device activity was almost entirely lost in an electrolyte solution $0.1 \mathrm{M} \mathrm{Na}_{2} \mathrm{~S}$ (pH 12.8) after $20 \mathrm{~min}$ [184]. The stability was increased up to $30 \mathrm{~min}$ when a carbon nanotube/polymer composite layer was used as waterproof coverage layer [185]. Also, Wang et al. reported an innovative functionalization of $\mathrm{CH}_{3} \mathrm{NH}_{3} \mathrm{PbI}_{3}$-based photoanode with $\mathrm{Ni}$ as protective layer against humidity showing $30 \mathrm{~min}$ stability and $2.08 \mathrm{~mA} / \mathrm{cm}^{2}$ value of the photogenerated current [186]. All these photoelectrodes are based on the planar perovskite solar cells, including expensive Au electrodes and hole transporting materials, making the final device very costly and irrelevant due to its unsatisfactory stability [187].

Inorganic perovskites having the $\mathrm{ABO}_{3}$ formula are of great interest for $\mathrm{H}_{2}$ and $\mathrm{O}_{2}$ production due to their exceptional stability and high photocatalytic activity. In Table 8 a series of different perovskites 
used as photoelectrodes for $\mathrm{H}_{2}$ and $\mathrm{O}_{2}$ generation via a photoelectrochemical water splitting reaction are presented.

Titanates were tested in photoelectrochemical water splitting in both acidic and basic environments. For example, $\mathrm{BaTiO}_{3}$ with a large band gap value $(3.11 \mathrm{eV})$ shows a photocurrent density of $0.007 \mathrm{~mA} / \mathrm{cm}^{2}$ at $0.5 \mathrm{~V}$ vs. SCE (saturated calomel electrode). The SCE electrode is a reference electrode based on mercury and mercury chloride [188]. The addition of $\mathrm{PbTiO}_{3}$ to $\mathrm{TiO}_{2}$ leads to a device with enhanced photoelectrochemical response $\left(0.3 \mathrm{~mA} / \mathrm{cm}^{2}\right.$ ) compared to pure $\mathrm{TiO}_{2}$ (almost $0 \mathrm{~mA} / \mathrm{cm}^{2}$ ) under visible light irradiation. The observed difference in the photocurrent density indicates that $\mathrm{PbTiO}_{3}$ acts as a visible light absorber [189]. Excellent photoelectrochemical activities are reported for $\mathrm{SrTiO}_{3}, \mathrm{CaTiO}_{3}$, $\mathrm{LaNiO}_{3}$ and $\mathrm{NaTaO}_{3}$ under UV radiation, but the utilization of visible light is restricted by their wide band gap values [190-196]. Therefore, perovskites having smaller band gap values are of interest in the photocatalytic field for enhanced water-splitting efficiencies. Ferrite perovskites are a class of materials which generally show the band gap energies in the visible region. The rhodamine $\mathrm{B}$ was successfully reduced under visible irradiation on $\mathrm{YFeO}_{3}$ that showed a much higher photocatalytic activity compared to $\mathrm{TiO}_{2}$ which possess a low absorption under visible light [197], and it was successfully tested in the form of both nanoparticles and compact films in photoelectrochemical production of $\mathrm{H}_{2}$ [198].

In particular, $\mathrm{BiFeO}_{3}(\mathrm{BFO})$ and $\mathrm{LaFeO}_{3}(\mathrm{LFO})$ were extensively utilized as photoelectrodes in photoelectrochemical applications, mostly for water photolysis and dye photodegradation. The dyes photodecomposition process will be detailed in the next section of this review. BFO is one of the few multiferroic materials at room temperature with a band gap value of ca. $2.7 \mathrm{eV}$ and an excellent photocatalytic activity [199]. The ferroelectric properties of BFO are able to improve the electron-hole separation and, hence, the photocatalytic activity. The effect of spontaneous polarization on the charge carriers separation is extensively detailed in literature [200]. Both undoped and doped BFO prepared by PLD were tested in photoelectrochemical applications as shown in Table 8. In $0.2 \mathrm{M}$ $\mathrm{Na}_{2} \mathrm{SO}_{4}$ electrolyte under sunlight illumination, the BFO photoanode generates a photocurrent density of $0.12 \mu \mathrm{A} / \mathrm{cm}^{2}$ at $0.8 \mathrm{~V}$ vs. $\mathrm{Ag} / \mathrm{AgCl}$. After the material was heated in a reductive atmosphere of hydrogen $(5 \%)$, the photocurrent increases ca. 6 times. The difference is due to smaller recombination and more efficient separation of free carriers on the hydrogen-treated sample [201]. A value of $17 \%$ for incident photon-to-current efficiency was reported for BFO photoelectrodes prepared by chemical vapour deposition (CVD). The modification of BFO surface with Ni improves the reaction kinetics and decreases the overpotential for water oxidation. The photocurrent density increases from 0.17 to $0.72 \mathrm{~mA} / \mathrm{cm}^{2}$ with $\mathrm{Ni}$ addition [202]. Nanowires as well as nanocubes of $\mathrm{BFO}$ generate only $\mathrm{O}_{2}$ when irradiated with UV light. A mixture of $\mathrm{BFO}$ and $\mathrm{SrTiO}_{3}(\mathrm{STO})$ can lead to $\mathrm{H}_{2}$ formation under visible light irradiation $[203,204]$. Also, in the case of polycrystalline BFO films, it was reported that by increasing the film crystallinity, the PEC response is enhanced. Moreover, the PEC response is strongly dependent on the spontaneous polarisation of BFO polycrystalline films [205,206]. Similarly, Cho et al. have reported epitaxial thin films of BFO deposited by PLD on STO showing excellent PEC properties [207]. Ti-doped BFO was reported to generate $0.04 \mathrm{~mA} / \mathrm{cm}^{2}$ at $1.23 \mathrm{~V}$ vs. RHE (reversible hydrogen electrode) in a basic solution of $\mathrm{NaOH}$ under UV irradiation [208]. The RHE is a reference electrode with the potential independent on the $\mathrm{pH}$ changes. The onset potential was ca. $0.81 \mathrm{~V}$ vs. RHE [208]. A detailed study on Y-doped BFO used as photoanode with high PEC efficiency for water splitting reaction $\left(\mathrm{J}_{\mathrm{ph}}=0.8 \mathrm{~mA} / \mathrm{cm}^{2}\right.$ at $1.4 \mathrm{~V}$ vs. RHE) was recently reported in literature [209]. Moreover, complex BFO-heterostructures were used as photoelectrodes for water splitting reaction. For example, nanofibers of $\mathrm{BiFeO}_{3} / \mathrm{Bi}_{2} \mathrm{Fe}_{4} \mathrm{O}_{9}$ with enhanced stability show higher efficiency for $\mathrm{H}_{2}$ production compared to pure $\mathrm{BFO}$ and $\mathrm{Bi}_{2} \mathrm{Fe}_{4} \mathrm{O}_{9}$. This improved efficiency was attributed to the formation of well-defined heterojunctions between the component materials, which helps the separation of charge carriers and avoids their recombination [210]. A significant increase in the photocurrent density compared to pure $\mathrm{BFO}$ was also observed for $\mathrm{BiFeO}_{3} / \mathrm{Fe}_{2} \mathrm{O}_{3}$. The heterostructure having a concentration of $9 \% \mathrm{Fe}_{2} \mathrm{O}_{3}$ shows a $\mathrm{J}_{\mathrm{ph}}$ value of ca. $0.19 \mathrm{~mA} / \mathrm{cm}^{2}$ (at $0.6 \mathrm{~V}$ vs. $\mathrm{Ag} / \mathrm{AgCl}$ ), using visible 
irradiation light, which is about three times higher than that obtained for pure $\mathrm{BFO}\left(0.055 \mathrm{~mA} / \mathrm{cm}^{2}\right)[211]$. Recently, a complex device based on $\mathrm{WO}_{3} / \mathrm{BiVO}_{4} / \mathrm{BiFeO}_{3} / \mathrm{FTO}$ (fluorine-doped tin oxide) was reported to show a huge value of the photocurrent density under solar irradiation in $0.5 \mathrm{M} \mathrm{Na}_{2} \mathrm{SO}_{4}$ electrolyte $\left(46.9 \mathrm{~mA} / \mathrm{cm}^{2}\right.$ at $2.53 \mathrm{~V}$ vs. RHE) [212]. The great response is correlated to the great separation of photogenerated charge carriers due to the similar band alignment of the three component materials deposited on the FTO substrate. The presence of an internal electric field at the $\mathrm{BiVO}_{3} / \mathrm{BFO}$ p-n junction interface together with BFO polarization, which improve the electron-hole pairs separation, have also been noticed [212].

$\mathrm{LaFeO}_{3}$ is a perovskite with a smaller band gap value than $\mathrm{BiFeO}_{3}$, more specifically ca. $2.07 \mathrm{eV}$, offering the possibility for a better absorption in the visible range $[180,213]$. Several years ago, Celorrio et al. studied the photoelectrochemical properties of nanostructured LFO photocathode manufactured by the screen-printed technique. They reported higher cathodic than anodic photocurrent values [214]. In screen-printed technology, the perovskite material is combined to an organic compound which is used to improve the adhesion to the substrate. The mixture is printed to the substrate using a heater, followed by calcination [215]. Also, in another study, the simultaneous generation of $\mathrm{O}_{2}$ and $\mathrm{H}_{2}$ using LFO powders was noted [216]. The values of the photogenerated current are around $0.8 \mathrm{~mA} / \mathrm{cm}^{2}$ at potentials higher than $1 \mathrm{~V}$ vs. $\mathrm{Ag} / \mathrm{AgCl}$ for utilisation of $\mathrm{LFO}$ as photoanode under simulated solar light [217]. Yu and coll. have deposited p-LFO and p-LFO/n- $\mathrm{Fe}_{2} \mathrm{O}_{3}$ on ITO (indium tin oxide) conductive substrates by PLD. The fabricated photocathodes show enhanced stability in alkaline $\mathrm{NaOH}$ electrolyte solution under visible irradiation even after $120 \mathrm{~h}$ [218]. May et al. [219] have reported an accurate study on the effect of thickness of $\mathrm{LaFeO}_{3} / \mathrm{Nb}: \mathrm{SrTiO}_{3}$ (LFO/STON) ultrathin films prepared by PLD on the photoelectrochemical properties. The cathodic photocurrent was shown to be strongly dependent on the film thickness, being observed only for samples with 10-25 nm thickness. The anodic photocurrent is observed for both thinner and thicker than $10 \mathrm{~nm}$ LFO films [219]. A photoanode based on Cu-doped LFO was reported to show a photocurrent density of $2 \mathrm{~mA} / \mathrm{cm}^{2}$ at $1.1 \mathrm{~V} v \mathrm{vs}$. $\mathrm{Ag} / \mathrm{AgCl}$ under visible irradiation [220]. Notably, no reports on utilization of devices based on heterostructures of $\mathrm{LFO} / \mathrm{BFO}$ perovskites for water splitting reaction have been published to date. 
Table 8. Photoelectrodes based on perovskites for photoelectrochemical water-splitting reaction.

\begin{tabular}{|c|c|c|c|c|c|c|}
\hline Material & Electrode Type & $\begin{array}{l}E_{g}{ }^{a} \\
(e V)\end{array}$ & Electrolyte/Light Source/Intensity $\left(\mathrm{mW} / \mathrm{cm}^{2}\right)$ & Performance & Stability & Ref. \\
\hline $\mathrm{BaTiO}_{3}$ & Photo-anode & 3.11 & $0.1 \mathrm{M} \mathrm{NaOH}(\mathrm{pH}=13) / \mathrm{Xe}$ arc UV-Vis lamp/180 & $\begin{array}{c}0.5 \mathrm{~V}_{\mathrm{SCE}}: \mathrm{J}_{\mathrm{ph}} \approx 0.07 \mathrm{~mA} / \mathrm{cm}^{2} \\
1.23 \mathrm{~V}_{\mathrm{RHE}}: \mathrm{J}_{\mathrm{ph}} \approx 0.3 \mathrm{~mA} / \mathrm{cm}^{2} \mathrm{IPCE}^{\mathrm{C}} \approx 70 \% \text { at } 380 \mathrm{~nm}\end{array}$ & n.s. ${ }^{b}$ & [188] \\
\hline $\mathrm{PbTiO}_{3}-\mathrm{TiO}_{2}$ & Photo-anode & $2.78-3.6$ & $0.1 \mathrm{M} \mathrm{KOH} / \mathrm{Xe} \mathrm{lamp} \mathrm{Vis} \mathrm{light}$ & $\begin{array}{c}\text { IPCE } \approx 38 \% \text { at } 420 \mathrm{~nm} \\
\text { IPCE }<1 \% \text { at } 500 \mathrm{~nm} \\
\text { Onset potential } 0.3 \mathrm{~V}_{\mathrm{RHE}} \\
0 \mathrm{~V}_{\mathrm{Ag} / \mathrm{Ag} \mathrm{Cl}}: \mathrm{J}_{\mathrm{ph}} \approx 0.5 \mathrm{uA} / \mathrm{cm}^{2}\end{array}$ & Stable after $300 \mathrm{~s}$ & [189] \\
\hline $\mathrm{SrTiO}_{3}$ nanocubes & Photo-anode & 3.43 & $0.1 \mathrm{Na}_{2} \mathrm{SO}_{4}(\mathrm{pH}=7) / \mathrm{AM} 1.5 / 100$ & $\begin{array}{c}0.9 \mathrm{~V}_{\mathrm{Ag} / \mathrm{AgCl}} \mathrm{J}_{\mathrm{ph}} \approx 4 \mathrm{uA} / \mathrm{cm}^{2} \\
60 \mu \mathrm{mol} / \mathrm{h} \mathrm{O}_{2}\end{array}$ & n.s. & [190] \\
\hline $\mathrm{SrTiO}_{3}$ & Photo-anode & 3.4 & $0.1 \mathrm{M} \mathrm{Na}_{2} \mathrm{SO}_{4 /} \mathrm{AM} 1.5 / 100$ & $\begin{array}{c}0 \mathrm{~V}_{\mathrm{Ag} / \mathrm{AgCl}} \mathrm{J}_{\mathrm{ph}} \approx 50 \mu \mathrm{AA} / \mathrm{cm}^{2} \\
1.5 \mathrm{~V}_{\mathrm{Ag} / \mathrm{AgCl}}: \mathrm{J}_{\mathrm{ph}} \approx 0.5 \mathrm{~mA} / \mathrm{cm}^{2} \mathrm{IPCE} \approx 10 \% \text { at } 350 \mathrm{~nm} \\
\mathrm{IPCE}<1 \% \text { for } \lambda>400 \mathrm{~nm} \\
0 \mathrm{~V}_{\mathrm{Ag} / \mathrm{AgCl}}: \mathrm{J}_{\mathrm{ph}} \approx 110 \mu \mathrm{A} / \mathrm{cm}^{2}\end{array}$ & n.s. & [191] \\
\hline $\begin{array}{c}\mathrm{SrTiO}_{3}-\text { carbon } \\
\text { quantum dots }\end{array}$ & Photo-anode & n.s. & $0.1 \mathrm{M} \mathrm{Na}_{2} \mathrm{SO}_{4} / \mathrm{AM} 1.5 / 100$ & $\begin{array}{c}1.5 \mathrm{~V}_{\mathrm{Ag} / \mathrm{AgCl}} \mathrm{J}_{\mathrm{ph}} \approx 1.7 \mathrm{~mA} / \mathrm{cm}^{2} \\
\mathrm{IPCE} \approx 14 \% \text { at } 350 \mathrm{~nm} \\
\mathrm{IPCE} \approx 1 \% \text { at } 860 \mathrm{~nm}\end{array}$ & n.s. & [192] \\
\hline $\mathrm{BiFeO}_{3}$ & Photo-anode & 2.1 & $0.2 \mathrm{M} \mathrm{Na}_{2} \mathrm{SO}_{4 / \text { sunlight } 300 \mathrm{~W} \text { Xenon lamp }}$ & $0.8 \mathrm{~V}_{\mathrm{Ag} / \mathrm{AgCl}} \mathrm{J}_{\mathrm{ph}} \approx 0.12 \mu \mathrm{A} / \mathrm{cm}^{2}$ & Stable after $400 \mathrm{~s}$ & [201] \\
\hline $\mathrm{H}_{2}$ treated $\mathrm{BiFeO}_{3}$ & Photo-anode & 2.0 & 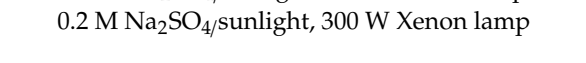 & $\begin{array}{c}0.8 \mathrm{~V}_{\mathrm{Ag} / \mathrm{AgCl}} \mathrm{J}_{\mathrm{ph}} \approx 0.69 \mu \mathrm{\mu A} / \mathrm{cm}^{2} \\
1 \mathrm{~V}\end{array}$ & Stable after $400 \mathrm{~s}$ & [201] \\
\hline $\mathrm{BiFeO}_{3}$ & Photo-anode & 2.4 & $0.2 \mathrm{M} \mathrm{Na}_{2} \mathrm{SO}_{4}(\mathrm{pH}=6.5) / \mathrm{AM} 1.5 / 100$ & $\begin{array}{l}1 \mathrm{~V}_{\mathrm{Ag} / \mathrm{AgCl}}: \mathrm{ph}_{\mathrm{ph}} \approx 0.17 \mathrm{~mA} / \mathrm{cm}^{2} \\
\text { IPCE } 17 \% \text { at } 420 \mathrm{~nm} \\
\text { Onset potential } 0.1 \mathrm{~V}_{\mathrm{Ag} / \mathrm{AgCl}}\end{array}$ & n.s. & [202] \\
\hline $\mathrm{Ni}-\mathrm{B} / \mathrm{BiFeO}_{3}$ & Photo-anode & n.s. & $0.1 \mathrm{M}$ potassium borate $(\mathrm{pH}=9.2)$ & $1 \mathrm{~V}_{\mathrm{Ag} / \mathrm{AgCl}}: \mathrm{J}_{\mathrm{ph}} \approx 0.72 \mathrm{~mA} / \mathrm{cm}^{2}$ & Stable after $3 \mathrm{~h}$ & [202] \\
\hline Ti-doped $\mathrm{BiFeO}_{3}$ & Photo-anode & 1.97 & $1 \mathrm{M} \mathrm{NaOH} / 300 \mathrm{~W}$ UV Xe lamp & $\begin{array}{c}1.23 \mathrm{~V}_{\mathrm{RHE}}: \mathrm{J}_{\mathrm{ph}} \approx 0.04 \mathrm{~mA} / \mathrm{cm}^{2} \\
\text { Onset potential } 0.81 \mathrm{~V} \mathrm{RHE}\end{array}$ & Stable after $3600 \mathrm{~s}$ & [208] \\
\hline Y-doped $\mathrm{BiFeO}_{3}$ & Photo-anode & n.s. & $0.5 \mathrm{M} \mathrm{NaOH}(\mathrm{pH}=13) /$ laser diode $405 \mathrm{~nm}(5 \mathrm{~mW})$ & $1.4 \mathrm{~V}_{\mathrm{RHE}}: \mathrm{J}_{\mathrm{ph}}=0.72 \mathrm{~mA} / \mathrm{cm}^{2}$ & Stable after $900 \mathrm{~s}$ & [209] \\
\hline $\mathrm{BiFeO}_{3} / \mathrm{TiO}_{2} / \mathrm{FTO}$ & Photo-anode & n.s. & $1 \mathrm{M} \mathrm{NaOH} / 300 \mathrm{~W}$ Xenon lamp Vis light & $\begin{array}{l}1.5 \mathrm{~V}_{\mathrm{SCE}}: \mathrm{J}_{\mathrm{ph}} \approx 15 \mathrm{~mA} / \mathrm{cm}^{2} \\
\text { Onset potential } \approx 0.6 \mathrm{~V}_{\mathrm{SCE}}\end{array}$ & Stable after $300 \mathrm{~s}$ & [222] \\
\hline $\mathrm{BiFeO}_{3} / \mathrm{TiO}_{2} / \mathrm{FTO}$ & Photo-anode & n.s. & $1 \mathrm{M} \mathrm{NaOH} / \mathrm{AM} 1.5 / 100$ & $\begin{array}{l}1.5 \mathrm{~V}_{\mathrm{SCE}}: \mathrm{J}_{\mathrm{ph}} \approx 17 \mathrm{~mA} / \mathrm{cm}^{2} \\
\text { Onset potential } \approx 0.6 \mathrm{~V}_{\mathrm{SCE}}\end{array}$ & Stable after $300 \mathrm{~s}$ & [222] \\
\hline
\end{tabular}


Table 8. Cont.

\begin{tabular}{|c|c|c|c|c|c|c|}
\hline Material & Electrode Type & $E_{g}{ }^{a}(e V)$ & Electrolyte/Light Source/Intensity $\left(\mathrm{mW} / \mathrm{cm}^{2}\right)$ & Performance & Stability & Ref. \\
\hline $\mathrm{WO}_{3} / \mathrm{BiVO}_{4} / \mathrm{BiFeO}_{3}$ & Photo-anode & n.s. & $0.5 \mathrm{M} \mathrm{Na}_{2} \mathrm{SO}_{4} / \mathrm{AM} 1.5 / 100$ & $2.53 \mathrm{~V}_{\text {RHE }}: \mathrm{J}_{\mathrm{ph}}=46.9 \mathrm{~mA} / \mathrm{cm}^{2}$ & Stable after $200 \mathrm{~s}$ & [212] \\
\hline $\mathrm{LaFeO}_{3}$ & Photo-cathode & 2.16 & $0.1 \mathrm{M} \mathrm{NaOH}(\mathrm{pH}=13) / \mathrm{AM} 1.5 / 100$ & $0.73 \mathrm{~V}_{\mathrm{RHE}}: \mathrm{J}_{\mathrm{ph}}=-0.1 \mathrm{~mA} / \mathrm{cm}^{2}$ & Stable after $1 \mathrm{~h}$ & [223] \\
\hline $\mathrm{LaFeO}_{3}$ & Photo-cathode & 2.16 & $0.1 \mathrm{M} \mathrm{NaOH}(\mathrm{pH}=13) / \mathrm{AM} 1.5 / 100$ & $0.5 \mathrm{~V}_{\mathrm{RHE}}: \mathrm{J}_{\mathrm{ph}} \approx-0.2 \mathrm{~mA} / \mathrm{cm}^{2}$ & Stable after $1 \mathrm{~h}$ & [223] \\
\hline $\mathrm{LaFeO}_{3}$ & Photo-anode & 2.08 & $0.1 \mathrm{M} \mathrm{KOH} / 500 \mathrm{~W}$ Xenon lamp, Vis light/100 & $\begin{array}{c}1.1 \mathrm{~V}_{\mathrm{Ag} / \mathrm{AgCl}}: \mathrm{J}_{\mathrm{ph}} \approx 1.2 \mathrm{~mA} / \mathrm{cm}^{2} \text { Onset potential } 0.48 \\
\mathrm{~V}_{\mathrm{Ag} / \mathrm{AgCl}}\end{array}$ & Stable after $330 \mathrm{~s}$ & [220] \\
\hline $\mathrm{LaFeO}_{3}$ & Photo-cathode & 2.4 & $0.1 \mathrm{M} \mathrm{NaOH}$ & $\begin{array}{c}0.26 \mathrm{~V}_{\mathrm{RHE}}: \mathrm{J}_{\mathrm{ph}} \approx 0.16 \mathrm{~mA} / \mathrm{cm}^{2} \text { Onset potential } 1.2 \\
\mathrm{~V}_{\mathrm{RHE}}\end{array}$ & Stable after $21 \mathrm{~h}$ & [224] \\
\hline $\mathrm{LaFeO}_{3}$ & Photo-cathode & 1.95 & $1 \mathrm{M} \mathrm{Na}_{2} \mathrm{SO}_{4} / \mathrm{AM} 1.5 / 100$ & $\begin{array}{c}1.7 \mathrm{~V}_{\mathrm{Ag} / \mathrm{AgCl}}: \\
\mathrm{J}_{\mathrm{ph}} \approx 8.2 \mathrm{~mA} / \mathrm{cm}^{2}\end{array}$ & $\begin{array}{l}\text { decreases to } 50 \% \\
\text { after } 30 \mathrm{~min}\end{array}$ & [225] \\
\hline $\mathrm{LaFeO}_{3}$ & Photo-anode & 2.07 & $0.1 \mathrm{M} \mathrm{NaOH}(\mathrm{pH}=13) /$ laser diode $405 \mathrm{~nm}(5 \mathrm{~mW})$ & $1 \mathrm{~V}_{\mathrm{Ag} / \mathrm{AgCl}}: \mathrm{J}_{\mathrm{ph}}=1.6 \mathrm{~mA} / \mathrm{cm}^{2}$ & n.s. & [128] \\
\hline $\mathrm{LaFe}_{0.9} \mathrm{Mn}_{0.1} \mathrm{O}_{3}$ & Photo-anode & $\sim 2.08$ & $0.1 \mathrm{M} \mathrm{KOH/500} \mathrm{W} \mathrm{Xenon} \mathrm{lamp,} \mathrm{Vis} \mathrm{light/100}$ & $\begin{array}{l}1.1 \mathrm{~V}_{\mathrm{Ag} / \mathrm{AgCl}}: \mathrm{J}_{\mathrm{ph}} \approx 1.5 \mathrm{~mA} / \mathrm{cm}^{2} \\
\quad \text { Onset potential } 0.34 \mathrm{~V}\end{array}$ & Stable after $330 \mathrm{~s}$ & [220] \\
\hline $\mathrm{LaFe}_{0.9} \mathrm{Co}_{0.1} \mathrm{O}_{3}$ & Photo-anode & $\sim 2.08$ & $0.1 \mathrm{M} \mathrm{KOH} / 500 \mathrm{~W}$ Xenon lamp, Vis light/100 & $\begin{array}{l}1.1 \mathrm{~V}_{\mathrm{Ag} / \mathrm{AgCl}}: \mathrm{J}_{\mathrm{ph}} \approx 1.8 \mathrm{~mA} / \mathrm{cm}^{2} \\
\quad \text { Onset potential } 0.27 \mathrm{~V}\end{array}$ & Stable after $330 \mathrm{~s}$ & [220] \\
\hline $\mathrm{LaFe}_{0.9} \mathrm{Cu}_{0.1} \mathrm{O}_{3}$ & Photo-anode & $\sim 2.08$ & $0.1 \mathrm{M} \mathrm{KOH} / 500 \mathrm{~W}$ Xenon lamp, Vis light/100 & $\begin{array}{l}1.1 \mathrm{~V}_{\mathrm{Ag} / \mathrm{AgCl}}: \mathrm{J}_{\mathrm{ph}} \approx 2 \mathrm{~mA} / \mathrm{cm}^{2} \\
\text { Onset potential } 0.27 \mathrm{~V}\end{array}$ & Stable after $330 \mathrm{~s}$ & [220] \\
\hline $\mathrm{p}-\mathrm{LaFeO}_{3} / \mathrm{n}-\mathrm{Fe}_{2} \mathrm{O}_{3}$ & $\begin{array}{l}\text { Photo-cathode/ } \\
\text { Photo-anode }\end{array}$ & n.s. & $1 \mathrm{M} \mathrm{NaOH} / \mathrm{AM} 1.5 / 100$ & $\begin{array}{c}0 \mathrm{~V}_{\mathrm{RHE}} \mathrm{J}_{\mathrm{ph}}=64.5 \mu \mathrm{AA} / \mathrm{cm}^{2} \\
11.5 \mu \mathrm{mol} / \mathrm{h} \mathrm{H}_{2} \\
5.7 \mu \mathrm{mol} / \mathrm{h} \mathrm{O}_{2}\end{array}$ & Stable after $120 \mathrm{~h}$ & [218] \\
\hline $\mathrm{LaFeO}_{3}$ & Photo-cathode & 2.4 & $0.1 \mathrm{M} \mathrm{NaOH} / \mathrm{AM} 1.5 / 100$ & $0.6 \mathrm{~V}_{\mathrm{RHE}}: \mathrm{J}_{\mathrm{ph}} \approx-0.04 \mathrm{~mA} / \mathrm{cm}^{2}$ & n.s. & [226] \\
\hline $\mathrm{Ag}-\mathrm{LaFeO}_{3}$ & Photo-cathode & n.s. & $1 \mathrm{M} \mathrm{NaOH} / \mathrm{AM} 1.5 / 100$ & $0.6 \mathrm{~V}_{\mathrm{RHE}}: \mathrm{J}_{\mathrm{ph}} \approx-0.074 \mathrm{~mA} / \mathrm{cm}^{2}$ & n.s. & [226] \\
\hline $\mathrm{LaFeO}_{3}$ & Photo-cathode & 2.07 & $0.1 \mathrm{M} \mathrm{Na}_{2} \mathrm{SO}_{4} / \mathrm{AM} 1.5 / 100$ & $0.6 \mathrm{~V}_{\mathrm{RHE}}: \mathrm{J}_{\mathrm{ph}} \approx-4.78 \mu \mathrm{A} / \mathrm{cm}^{2}$ & $\begin{array}{l}\text { decreases to } 88.6 \% \\
\text { after } 2750 \mathrm{~s}\end{array}$ & [227] \\
\hline $\mathrm{FTO} / \mathrm{Au} / \mathrm{LaFeO}_{3}$ & Photo-cathode & n.s. & $0.1 \mathrm{M} \mathrm{Na}_{2} \mathrm{SO}_{4} / \mathrm{AM} 1.5 / 100$ & $0.6 \mathrm{~V}_{\mathrm{RHE}}: \mathrm{J}_{\mathrm{ph}} \approx-19.60 \mu \mathrm{A} / \mathrm{cm}^{2}$ & $\begin{array}{l}\text { decreases to } 91 \% \\
\text { after } 2750 \mathrm{~s}\end{array}$ & [227] \\
\hline
\end{tabular}

${ }^{\mathrm{a}} \mathrm{E}_{\mathrm{g}}$-band gap; ${ }^{\mathrm{b}}$ n.s. - not specified; ${ }^{\mathrm{C}} \mathrm{ICPE}-$ Incident Photon to Current Efficiency. 
The utilization of co-catalysts can further improve the global efficiency of water splitting reaction. Generally, noble metals $(\mathrm{Pt}, \mathrm{Rh}, \mathrm{Pd})$ and metal oxides $\left(\mathrm{NiO}, \mathrm{RuO}_{2}\right)$ are extensively used as co-catalysts. When a photoelectrode is loaded with a co-catalyst, the photogenerated electrons which arrive at the surface are entrapped by the co-catalyst. In this way, the utilisation of co-catalysts, stimulates the surface chemical reaction and constrains the backward reaction, leading to an increased overall water splitting efficiency [90]. A schematic representation of a photocatalyst and a photoelectrode loaded by co-catalysts is presented in Figure 14.

Photoelectrochemical system

(b) Co-catalyst deposition

Photocatalytic system

(a) Co-catalyst deposition

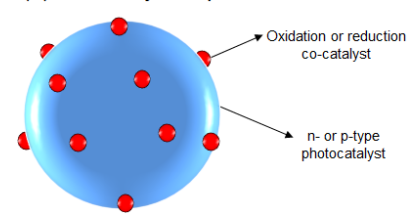

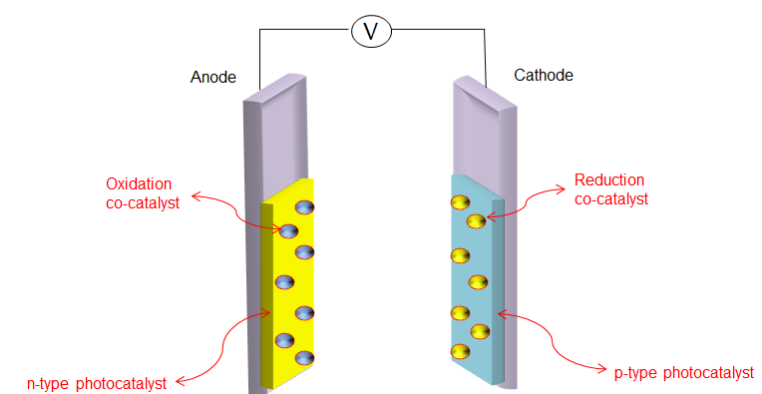

Figure 14. The schematically representation of (a) photocatalyst; (b) photoelectrode loaded by co-catalysts. Adapted from reference [168].

Also, the working principle of the reaction in the presence of photocatalysts (a) and photoelectrodes (b) loaded with an oxidation co-catalyst for both dark and illuminated processes is illustrated in Figure 15.
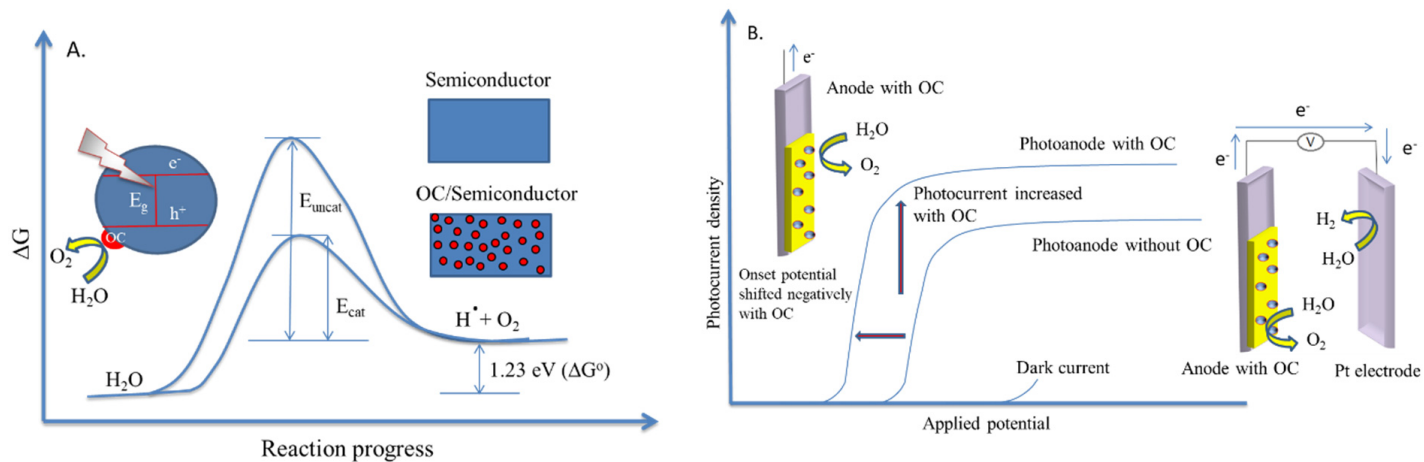

Figure 15. The working principle of the reaction in the presence of photocatalysts (A) and photocurrent density vs. the applied potential curves of photoelectrodes (B) loaded with an oxidation co-catalyst for both dark and illuminated processes, where OC-oxidation cocatalyst, $\mathrm{E}_{\text {uncat }}$-activation energy without OC and $E_{\text {cat }}$-activation energy with OC. Adapted from references $[168,228]$.

Polycrystalline films of BFO synthesized via the citrate method, decorated with nanoparticles of Ag which act as co-catalysts, were reported. This heterostructure shows almost two times higher photocurrent density compared to pure BFO [229]. Also, a device based on reduced graphene oxide $(\mathrm{rGO}) / \mathrm{BFO}$ was reported to ensure an excellent charge carriers separation, leading in this way to a higher IPCE [230]. Moreover, thin films of $\mathrm{BiFeO}_{3}$ show water-splitting activity without any external bias applied [200,221].

\subsubsection{Catalytic Combustion of Methane}

Natural gas (a hydrocarbon gas mixture consisting mainly of methane) has a major impact on our lives, being one of the most used energy sources. Thermal combustion of light hydrocarbons meets many challenges because of its low efficiency and high pollution degree. This conventional combustion 
process takes place at high temperatures (above $1300^{\circ} \mathrm{C}$ ) generating high amounts of nitrogen oxides $\left(\mathrm{NO}_{\mathrm{x}}\right)$, which severely affect the environment and, furthermore, human health. In the last few years, the market request has shown a significant increase of fuel consumption, leading, at the same time, to an advanced pollution risk. The catalytic combustion is preferred instead of the flame combustion due to its major advantages, such as enhanced fuel efficiency and lower emission of pollutants in the exhaust gas [3,5]. Important quantities of methane $\left(\mathrm{CH}_{4}\right)$ are annually consumed in the fuel industry, it being considered one of the cleanest sources of fossil energy [231]. The simplified chemical reaction of methane combustion is:

$$
\mathrm{CH}_{4}+2 \mathrm{O}_{2} \rightarrow \mathrm{CO}_{2}+2 \mathrm{H}_{2} \mathrm{O}
$$

However, beside the production of $\mathrm{CO}_{2}$ and $\mathrm{H}_{2} \mathrm{O}$, during the methane combustion process, many other reactions can take place, such as partial combustion of methane with $\mathrm{CO}$ formation, steam reforming and others [232]:

$$
\begin{gathered}
\mathrm{CH}_{4}+3 / 2 \mathrm{O}_{2} \Rightarrow \mathrm{CO}+2 \mathrm{H}_{2} \mathrm{O} \\
\mathrm{CH}_{4}+\mathrm{H}_{2} \mathrm{O} \rightleftarrows \mathrm{CO}+3 \mathrm{H}_{2} \\
2 \mathrm{H}_{2}+\mathrm{O}_{2} \Rightarrow 2 \mathrm{H}_{2} \mathrm{O} \\
\mathrm{CO}+\mathrm{H}_{2} \mathrm{O} \rightleftarrows \mathrm{CO}_{2}+\mathrm{H}_{2} \\
2 \mathrm{CO}+\mathrm{O}_{2} \Rightarrow 2 \mathrm{CO}_{2}
\end{gathered}
$$

In contrast to the classical combustion, the heterogeneous catalytic combustion of methane operates at lower temperatures $\left(<800{ }^{\circ} \mathrm{C}\right)$, increases the conversion efficiency of methane into energy, and severely decreases the atmospheric pollutants emission [233]. It is worth noting that catalytic combustion of methane is important not only for power generation but, also, for air pollution abatement [234]. The ideal catalyst for methane combustion is required to possess high thermal and chemical stability, but at the same time it should present catalytic oxidation activity in the low-temperature range [4]. The most promising low-temperature catalysts for this reaction are the supported noble metals. Excellent catalytic activities for methane combustion are reported on supported platinum [235], rhodium [236] and palladium [237]. Unfortunately, they are expensive and in a strong oxidative atmosphere they are susceptible to form volatile oxides leading to a decrease of the catalytic activity. Also, at high temperatures, the noble metal particles tend to accumulate and to form a compact material (the so-called sintering effect). This effect decreases the specific surface area (SSA) of the catalyst and, implicitly, its catalytic activity [4]. These disadvantages made researchers look for a possible replacement of this kind of catalysts. A good alternative is to use active catalysts for hydrocarbons combustion based on single or binary oxides of transition metals. A few single oxides active for hydrocarbons combustion are $\mathrm{Co}_{3} \mathrm{O}_{4}, \mathrm{CuO}, \mathrm{NiO}, \mathrm{MnO}_{2}$. The combination of oxides generally gives a greater thermal stability and higher combustion activity compared to the single oxides [45].

Inorganic perovskites $\mathrm{ABO}_{3}$ have been found to be adequate catalysts for total oxidation since they combine the high catalytic activity with the low volatility [3]. For the perovskite-type oxide catalysts, two types of oxygen species having different bonding strength are present: (i) adsorbed on the surface and (ii) lattice oxygen. It is believed that the adsorbed oxygen is more active, reacting with methane at lower temperatures than the lattice oxygen. At higher temperatures, the coverage of the adsorbed oxygen decreases, while the lattice oxygen becomes highly active. Voorhoeve et al. have proposed two reaction types for catalytic combustion of methane over perovskite materials: suprafacial and intrafacial. The suprafacial reaction is mainly present at low temperature, while with increasing the temperature, the intrafacial process occurs [45].

Table 9 presents the performances of different undoped perovskites used as catalysts for methane combustion. Lanthanum cobaltate $\left(\mathrm{LaCoO}_{3}\right)$, having a SSA smaller than $15 \mathrm{~m}^{2} / \mathrm{g}$. shows $\mathrm{T}_{50}$ (temperature corresponding to $50 \%$ methane conversion) values ranging between 525 and $709^{\circ} \mathrm{C}[45,50,56-59,63,64]$ depending on the reaction conditions, i.e., methane and oxygen 
concentrations in the feed gas and the magnitude of the gas flow rate. With the increase of the SSA, $\mathrm{T}_{50}$ decreases, reaching a minimum temperature of $449^{\circ} \mathrm{C}$ for $\mathrm{LaCoO}_{3}$ with an SSA of $43 \mathrm{~m}^{2} / \mathrm{g}$ [65]. This temperature can be further lowered by adding noble metals (e.g., $\mathrm{Pt}, \mathrm{Pd}$ ) to the $\mathrm{LaCoO}_{3}$ perovskite structure [61]. The replacement of $\mathrm{La}^{3+}$ with $\mathrm{Pr}^{3+}$ leads to a major increase of $\mathrm{T}_{50}$ and of the activation energy $\left(E_{a}\right)$, which is, in fact, the required energy for a chemical reaction to take place. This behavior is correlated to the redox properties of $\mathrm{Pr}^{4+} / \mathrm{Pr}^{3+}$ couple which can affect the valence state of cobalt ions during methane combustion reaction [56]. Lanthanum manganate $\left(\mathrm{LaMnO}_{3}\right)$ shows excellent catalytic activity for the methane combustion with $\mathrm{T}_{50}$ in the $500-600^{\circ} \mathrm{C}$ interval $[50,55,57,64,70,72,75,80,82,238]$. However, the value of $\mathrm{T}_{50}$ can be further decreased by changing the synthesis method of $\mathrm{LaMnO}_{3}$ perovskites. For example, $\mathrm{LaMnO}_{3}$ prepared by the flame-hydrolysis method shows a $\mathrm{T}_{50}$ of $489^{\circ} \mathrm{C}$, while that prepared by the citric acid and flame pyrolysis methods show $\mathrm{T}_{50}$ values of 446 and $435^{\circ} \mathrm{C}$, respectively $[61,65,66]$. No major changes in the catalytic activity were observed when $\mathrm{La}^{3+}$ was replaced by $\mathrm{Pr}^{3+}$ or $\mathrm{Gd}^{3+}$ [69]. However, it severely decreases for $\mathrm{NdMnO}_{3}$ and $\mathrm{SmMnO}_{3}$ because of their easier reductibility [72]. It is worth noting that, due to its good thermal stability and high activity, which are further improved after dispersion on a lanthanum-stabilized alumina-coated monolith [70], $\mathrm{LaMnO}_{3}$ is an active phase of choice in high-pressure structured catalytic combustors [239-243]. Lanthanum ferrite $\left(\mathrm{LaFeO}_{3}\right)$, which shows the highest stability compared to $\mathrm{LaCoO}_{3}, \mathrm{LaNiO}_{3}$ and $\mathrm{LaMnO}_{3}$, displays a catalytic activity similar to $\mathrm{LaMnO}_{3}[3,45,57,61,63-65,69,76-78,244]$. Ciambeli et al. have reported a detailed study on ferrite perovskites $\left(\mathrm{AFeO}_{3}\right)$ containing different rare earth cations $\left(\mathrm{La}^{3+}, \mathrm{Sm}^{3+}, \mathrm{Nd}^{3+}\right)$ in A sites. It was demonstrated that $\mathrm{LaFeO}_{3}$ catalyst shows the best catalytic activity for methane combustion, with total selectivity to $\mathrm{CO}_{2}$, having the $\mathrm{T}_{50}=528{ }^{\circ} \mathrm{C}$ and the temperature corresponding to $90 \%$ methane conversion $\left(\mathrm{T}_{90}\right)$ of ca. $615^{\circ} \mathrm{C}$ [77]. Spinicci et al. have revealed that $\mathrm{La}_{0.9} \mathrm{FeO}_{2.85}$ shows better activity compared to stoichiometric $\mathrm{LaFeO}_{3}$. The further decrease of lanthanum and oxygen contents leads to the loss of the catalytic activity [245]. The catalytic activity can be limited by the low specific surface area of the perovskite catalysts [45]. One of the most used methods to increase the SSA of catalysts based on perovskites is to disperse them on appropriate supports [246]. Indeed, it has been shown that the SSA of the unsupported $\mathrm{BaTiO}_{3}$ and $\mathrm{PbTiO}_{3}$ increased from 0.4 and $0.5 \mathrm{~m}^{2} / \mathrm{g}$, respectively, to 193 and $175 \mathrm{~m}^{2} / \mathrm{g}$ for their alumina-supported counterparts, respectively. The increase of the SSA led to an enhanced catalytic activity for methane combustion $[44,247]$.

Table 9. Methane combustion activity of undoped perovskite-type materials expressed as the temperature where $50 \%$ conversion is reached $\left(T_{50}\right)$.

\begin{tabular}{|c|c|c|c|c|c|}
\hline Catalyst & $\mathrm{SSA}\left(\mathrm{m}^{2} / \mathrm{g}\right)$ & Reaction Conditions & $\begin{array}{l}\mathrm{T}_{50} \\
\left({ }^{\circ} \mathrm{C}\right)\end{array}$ & $\begin{array}{c}E_{a^{a}} \\
(\mathrm{~kJ} / \mathrm{mol})\end{array}$ & Ref. \\
\hline $\mathrm{LaCoO}_{3}$ & 3.0 & 2 vol. $\% \mathrm{CH}_{4}$ in air, $45,000-50,000 / \mathrm{h}$ & 525 & 22.1 & [45] \\
\hline $\mathrm{LaCoO}_{3}$ & 3.5 & 1 vol. $\% \mathrm{CH}_{4}, 4$ vol. $\% \mathrm{O}_{2}$ in $\mathrm{He}, 135,000 / \mathrm{h}$ & 709 & $\sim 104$ & [56] \\
\hline $\mathrm{LaCoO}_{3}$ & 5.7 & 3 vol. $\% \mathrm{CH}_{4}, 7.2$ vol. $\% \mathrm{O}_{2}$ in $\mathrm{N}_{2}, 113 \mathrm{~cm}^{3} / \mathrm{min}, 0.5 \mathrm{~g}$ catalyst & $\sim 647$ & n.s. ${ }^{b}$ & {$[63]$} \\
\hline $\mathrm{LaCoO}_{3}$ & 8 & 1 vol. $\% \mathrm{CH}_{4}$ in air & 545 & n.s. & [57] \\
\hline $\mathrm{LaCoO}_{3}$ & 15.0 & 0.4 vol. $\% \mathrm{CH}_{4}, 10$ vol. $\% \mathrm{O}_{2}$ in $\mathrm{N}_{2}, 40,000 \mathrm{Ncm}^{3} / \mathrm{h} \mathrm{x} \mathrm{gat}_{\text {cat }}$ & $\sim 567$ & n.s. & {$[50]$} \\
\hline $\mathrm{LaCoO}_{3+x}$ & $15.6-22.8$ & $10 \mathrm{~cm}^{3}\left(1.04\right.$ vol. $\% \mathrm{CH}_{4}$ in $\left.\mathrm{He}\right)$ with $10 \mathrm{~cm}^{3}$ of air, $0.2 \mathrm{~g}$ catalyst & 466 & n.s. & {$[65]$} \\
\hline $\mathrm{LaCoO}_{3}$ & 11.3 & 1 vol. $\% \mathrm{CH}_{4}$ in air, $45,000 \mathrm{~mL} /\left(\mathrm{h} \mathrm{g}_{\text {cat }}\right), 0.1 \mathrm{~g}$ catalyst & 600 & 97 & {$[58]$} \\
\hline $\mathrm{LaCoO}_{3}$ & 6.0 & 1 vol. $\% \mathrm{CH}_{4}, 4$ vol. $\% \mathrm{O}_{2}$ in $\mathrm{He}, 20,000-200,000 / \mathrm{h}, 0.1 \mathrm{~g}$ catalyst & $\sim 600$ & n.s. & [59] \\
\hline $\mathrm{LaCoO}_{3}$ & 43 & 0.34 vol. $\% \mathrm{CH}_{4}, 33.3$ vol. $\%$ air in $\mathrm{He}, 30 \mathrm{Ncm}^{3} / \mathrm{min}, 0.15 \mathrm{~g}$ catalyst & 449 & n.s. & [61] \\
\hline $\mathrm{LaCoO}_{3}$ & 5.5 & 1 vol. $\% \mathrm{CH}_{4}, 4$ vol. $\% \mathrm{O}_{2}$ in $\mathrm{He}, 14,150 / \mathrm{h}, 0.1 \mathrm{~g}$ catalyst & 560 & n.s. & {$[64]$} \\
\hline $\mathrm{PrCoO}_{3}$ & 5.1 & & 903 & $\sim 110$ & [56] \\
\hline $\mathrm{NdCoO}_{3}$ & 1.6 & 1 vol. $\% \mathrm{CH} 4,4$ vol. $\% \mathrm{O}_{2}$ in $\mathrm{He}, 135,000 / \mathrm{h}$ & 658 & $\sim 103$ & \\
\hline $\mathrm{GdCoO}_{3}$ & 2.1 & & 733 & $\sim 99$ & \\
\hline $\mathrm{LaMnO}_{3}$ & 4.0 & 2 vol. $\% \mathrm{CH}_{4}$ in air, $45,000-5000 / \mathrm{h}$ & 579 & 21.8 & [45] \\
\hline $\mathrm{LaMnO}_{3}$ & $\sim 15$ & 1.5 vol. $\% \mathrm{CH}_{4}, 4.2$ vol. $\% \mathrm{O}_{2}$ in $\left.\mathrm{He}\right), 200 \mathrm{~cm}^{3} / \mathrm{min}, 0.004 \mathrm{~g}$ catalyst & n.s. & 73 & [3] \\
\hline $\mathrm{LaMnO}_{3}$ & 5.6 & 3.2 vol. $\% \mathrm{CH}_{4}, 12.8$ vol. $\% \mathrm{O}_{2}$ in $\mathrm{Ar}, 73.5 \mathrm{~mL} / \mathrm{min}$ & 457 & 92 & [49] \\
\hline $\mathrm{LaMnO}_{3+\mathrm{x}}$ & 8.0 & 1 vol. $\% \mathrm{CH}_{4}, 4$ vol. $\% \mathrm{O}_{2}$ in $\mathrm{He}, 135,000 / \mathrm{h}$ & 682 & $\sim 82$ & [69] \\
\hline $\mathrm{LaMnO}_{3}$ & 7 & 1 vol. $\% \mathrm{CH}_{4}$ in air & 580 & n.s. & [57] \\
\hline $\mathrm{LaMnO}_{3}$ & n.s. & 1 vol. $\% \mathrm{CH}_{4}$ in air, $\sim 50,000 \mathrm{~cm}^{3} /\left(\mathrm{h} \mathrm{g}_{\text {cat }}\right)$ & $\sim 577$ & n.s. & {$[75]$} \\
\hline $\mathrm{LaMnO}_{3}$ & 20.0 & 0.5 vol. $\% \mathrm{CH}_{4}, 10$ vol. $\%$ air in $\mathrm{N}_{2}, 40 \mathrm{Ncm}^{3} / \mathrm{min}, 0.2 \mathrm{~g}$ catalyst & $\sim 440$ & n.s. & {$[71]$} \\
\hline $\mathrm{LaMnO}_{3}$ & 22.0 & 0.4 vol. $\% \mathrm{CH}_{4}, 10$ vol. $\% \mathrm{O}_{2}$ in $\mathrm{N}_{2}, 40,000 \mathrm{Ncm}^{3} /$ (h g gat $)$ & $\sim 506$ & n.s. & {$[50]$} \\
\hline $\mathrm{LaMnO}_{3}$ & 20.0 & 0.4 vol. $\% \mathrm{CH}_{4}, 10$ vol. $\% \mathrm{O}_{2}$ in $\mathrm{N}_{2}$ & $\sim 507$ & 23.3 & {$[72]$} \\
\hline $\mathrm{LaMnO}_{3}$ & 11.0 & 0.4 vol. $\% \mathrm{CH}_{4}, 10$ vol. $\% \mathrm{O}_{2}$ in $\mathrm{N}_{2}$ & 575 & 24.4 & {$[70]$} \\
\hline $\mathrm{LaMnO}_{3+\mathrm{x}}$ & $15.6-22.8$ & $10 \mathrm{~cm}^{3}$ (1.04 vol. $\% \mathrm{CH}_{4}$ in He) with $10 \mathrm{~cm}^{3}$ of air, $0.2 \mathrm{~g}$ catalyst & 489 & n.s. & [65] \\
\hline $\mathrm{LaMnO}_{3}$ & n.s. & 0.4 vol. $\% \mathrm{CH}_{4}, 10$ vol. $\% \mathrm{O}_{2}$ in $\mathrm{N}_{2}, 40,000 \mathrm{Ncm}^{3} /\left(\mathrm{h} \mathrm{g}_{\mathrm{cat}}\right), 0.4 \mathrm{~g}$ catalyst & 511 & 97.5 & [238] \\
\hline $\mathrm{LaMnO}_{3}$ & 22.0 & 0.4 vol. $\% \mathrm{CH}_{4}, 10$ vol. $\% \mathrm{O}_{2}$ in $\mathrm{N}_{2}, 40,000 \mathrm{~cm}^{3} /\left(\mathrm{h} \mathrm{g}_{\text {cat }}\right), 0.4$ g catalyst & $\sim 507$ & 23.3 & {$[55]$} \\
\hline $\mathrm{LaMnO}_{3}$ & 56 & 0.34 vol. $\% \mathrm{CH}_{4}, 33.3$ vol. $\%$ air in $\mathrm{He}, 30 \mathrm{Ncm}^{3} / \mathrm{min}, 0.15 \mathrm{~g}$ catalyst & 435 & n.s. & {$[61]$} \\
\hline
\end{tabular}


Table 9. Cont.

\begin{tabular}{|c|c|c|c|c|c|}
\hline Catalyst & $\operatorname{SSA}\left(\mathrm{m}^{2} / \mathrm{g}\right)$ & Reaction Conditions & $\begin{array}{l}\mathrm{T}_{50} \\
\left({ }^{\circ} \mathrm{C}\right)\end{array}$ & $\begin{array}{c}E_{a^{a}} \\
(k J / m o l)\end{array}$ & Ref. \\
\hline $\mathrm{LaMnO}_{3}$ & 21.8 & 1 vol. $\% \mathrm{CH}_{4}, 4$ vol. $\% \mathrm{O}_{2}$ in $\mathrm{He}, 14,150 / \mathrm{h}, 0.1 \mathrm{~g}$ catalyst & 515 & n.s. & [64] \\
\hline $\mathrm{LaMnO}_{3}$ & 68 & 1 vol. $\% \mathrm{CH}_{4}, 4$ vol. $\% \mathrm{O}_{2}$ in $\mathrm{N}_{2}, 40,000 \mathrm{~cm}^{3} /\left(\mathrm{h} \mathrm{g}_{\text {cat }}\right), 0.15 \mathrm{~g}$ catalyst & 446 & n.s. & [66] \\
\hline $\begin{array}{c}30 \% \mathrm{LaMnO}_{3 /} \\
\left(5 \% \mathrm{La}_{2} \mathrm{O}_{3} / \mathrm{Al}_{2} \mathrm{O}_{3}\right)\end{array}$ & 88.0 & \multirow[t]{2}{*}{0.4 vol. $\% \mathrm{CH}_{4}, 10$ vol. $\% \mathrm{O}_{2}$ in $\mathrm{N}_{2}$} & 532 & 18.2 & [70] \\
\hline $20 \% \mathrm{LaMnO}_{3} / \mathrm{MgO}$ & 25.0 & & 533 & 23.3 & \\
\hline $\mathrm{LaMnO}_{3}-\mathrm{ZrO}_{2}$ & 132.5 & \multirow{2}{*}{2 vol. $\% \mathrm{CH}_{4}, 16$ vol. $\% \mathrm{O}_{2}$ in $\mathrm{He}, 50 \mathrm{Ncm}^{3} / \mathrm{min}, 0.1 \mathrm{~g}$ catalyst } & 595 & n.s. & [82] \\
\hline $\mathrm{Pd} / \mathrm{LaMnO}_{3}-\mathrm{ZrO}_{2}$ & 74.6 & & 570 & n.s. & \\
\hline $0.5 \% \mathrm{Pt} / \mathrm{LaMnO}_{3}$ & 63 & \multirow{2}{*}{0.34 vol. $\% \mathrm{CH}_{4}, 33.3$ vol. $\%$ air in $\mathrm{He}, 30 \mathrm{Ncm}^{3} / \mathrm{min}, 0.15 \mathrm{~g}$ catalyst } & 426 & n.s. & [61] \\
\hline $0.5 \% \mathrm{Pd} / \mathrm{LaMnO}_{3}$ & 53 & & 445 & n.s. & \\
\hline $\begin{array}{l}\mathrm{LaMnO}_{3} / \mathrm{foil} \\
\mathrm{Fe}_{2} \mathrm{Cr}_{20} \mathrm{Al}_{5}\end{array}$ & 23.3 & $\begin{array}{c}1 \text { vol. } \% \mathrm{CH}_{4} \text { in air, } \\
64,410 \mathrm{~cm}^{3} /\left(\mathrm{h} \mathrm{g}_{\text {cat }}\right), 25.7 \mathrm{~g} \text { catalyst }\end{array}$ & 566 & n.s. & [80] \\
\hline $\mathrm{PrMnO}_{3+\mathrm{x}}$ & 2.5 & \multirow{2}{*}{1 vol. $\% \mathrm{CH}_{4}, 4$ vol. $\% \mathrm{O}_{2}$ in $\mathrm{He}, 135,000 / \mathrm{h}$} & 711 & $\sim 89$ & \multirow[t]{2}{*}{ [69] } \\
\hline $\mathrm{NdMnO}_{3+\mathrm{x}}$ & 2.4 & & 695 & $\sim 83$ & \\
\hline $\mathrm{NdMnO}_{3}$ & 20.0 & 0.4 vol. $\% \mathrm{CH}_{4}, 10$ vol. $\% \mathrm{O}_{2}$ in $\mathrm{N}_{2}$ & $\sim 587$ & 19.3 & [72] \\
\hline $\mathrm{GdMnO}_{3+\mathrm{x}}$ & 5.3 & 1 vol. $\% \mathrm{CH}_{4}, 4$ vol. $\% \mathrm{O}_{2}$ in $\mathrm{He}, 135,000 / \mathrm{h}$ & 677 & $\sim 79$ & [69] \\
\hline $\mathrm{SmMnO}_{3}$ & 19.0 & 0.4 vol. $\% \mathrm{CH}_{4}, 10$ vol. $\% \mathrm{O}_{2}$ in $\mathrm{N}_{2}$ & $\sim 527$ & 17.1 & [72] \\
\hline $\mathrm{LaFeO}_{3}$ & 3.1 & 2 vol. $\% \mathrm{CH}_{4}$ in air, $45,000-5000 / \mathrm{h}$ & 571 & 18.2 & [45] \\
\hline $\mathrm{LaFeO}_{3}$ & 5.5 & 1.5 vol. $\% \mathrm{CH}_{4}, 4.2$ vol. $\% \mathrm{O}_{2}$ in $\mathrm{He}, 200 \mathrm{~cm}^{3} / \mathrm{min}, 0.004 \mathrm{~g}$ catalyst & n.s. & 75 & [3] \\
\hline $\mathrm{LaFeO}_{3}$ & 3.0 & n.s. & $\sim 672$ & n.s. & [63] \\
\hline $\mathrm{LaFeO}_{3}$ & 10 & 1 vol. $\% \mathrm{CH}_{4}$ in air & 545 & n.s. & [57] \\
\hline $\mathrm{LaFeO}_{3}$ & 2.9 & 0.4 vol. $\% \mathrm{CH}_{4}, 10$ vol. $\% \mathrm{O}_{2}$ in $\mathrm{N}_{2}, 40,000 \mathrm{Ncm}^{3} /\left(\mathrm{h} \mathrm{g}_{\text {cat }}\right)$ & 529 & 20.76 & [77] \\
\hline $\mathrm{LaFeO}_{3}$ & 3.0 & 0.4 vol. $\% \mathrm{CH}_{4}, 10$ vol. $\% \mathrm{O}_{2}$ in $\mathrm{N}_{2}, 40,000 \mathrm{Ncm}^{3} /\left(\mathrm{h} \mathrm{g}_{\text {cat }}\right), 0.4 \mathrm{~g}$ catalyst & 529 & 21.07 & [78] \\
\hline $\mathrm{LaFeO}_{3}$ & 20.9 & 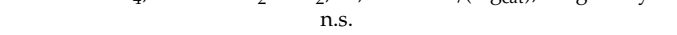 & 608 & n.s. & [76] \\
\hline $\mathrm{LaFeO}_{3}$ & 19.5 & & 508 & & \\
\hline $\mathrm{LaFeO}_{3}$ & 38 & 0.34 vol. $\% \mathrm{CH}_{4}, 33.3$ vol. $\%$ air in $\mathrm{He}, 30 \mathrm{Ncm}^{3} / \mathrm{min}, 0.15 \mathrm{~g}$ catalyst & 495 & n.s. & [61] \\
\hline $\mathrm{LaFeO}_{3}$ & 9.8 & 1 vol. $\% \mathrm{CH}_{4}, 4$ vol. $\% \mathrm{O}_{2}$ in $\mathrm{He}, 14,150 / \mathrm{h}, 0.1 \mathrm{~g}$ catalyst & 625 & n.s. & [64] \\
\hline $\mathrm{LaFeO}_{3}$ & 21.0 & 37,000 ppmv $\mathrm{CH}_{4}, 23.22$ vol. $\% \mathrm{O}_{2}$ in $\mathrm{He}$ & 512 & 105.7 & [79] \\
\hline $\mathrm{LaFeO}_{3+x}$ & 15.6 & $10 \mathrm{~cm}^{3}$ (1.04 vol. $\% \mathrm{CH}_{4}$ in $\left.\mathrm{He}\right)$ with $10 \mathrm{~cm}^{3}$ of air, $0.2 \mathrm{~g}$ catalyst & 472 & n.s. & [65] \\
\hline $\mathrm{LaFeO}_{3+x}$ & 3.5 & 1 vol. $\% \mathrm{CH}_{4}, 4$ vol. $\% \mathrm{O}_{2}$ in $\mathrm{He}, 135,000 / \mathrm{h}$ & 678 & $\sim 105$ & [69] \\
\hline $\mathrm{LaFeO}_{3} / \mathrm{FeCr}(20 \%) \mathrm{Al}(5 \%)$ & 7.7 & 1 vol. $\% \mathrm{CH}_{4}$ in air, $5800 / \mathrm{h}$ & 577 & 101.8 & [81] \\
\hline $\mathrm{PrFeO}_{3+x}$ & 5.8 & \multirow{2}{*}{1 vol. $\% \mathrm{CH}_{4}, 4$ vol. $\% \mathrm{O}_{2}$ in $\mathrm{He}, 135,000 / \mathrm{h}$} & 717 & 86 & [69] \\
\hline $\mathrm{NdFeO}_{3+x}$ & 4.5 & & 718 & $\sim 109$ & \\
\hline $\mathrm{NdFeO}_{3}$ & 2.3 & 0.4 vol. $\% \mathrm{CH}_{4}, 10$ vol. $\% \mathrm{O}_{2}$ in $\mathrm{N}_{2}, 40,000 \mathrm{Ncm}^{3} /\left(\mathrm{h} \mathrm{g}_{\text {cat }}\right)$ & 556 & 20.76 & [77] \\
\hline $\mathrm{GdFeO}_{3+x}$ & 5.6 & 1 vol. $\% \mathrm{CH}_{4}, 4$ vol. $\% \mathrm{O}_{2}$ in $\mathrm{He}, 135,000 / \mathrm{h}$ & 707 & $\sim 89$ & [69] \\
\hline $\mathrm{SmFeO}_{3}$ & 4.3 & 0.4 vol. $\% \mathrm{CH}_{4}, 10$ vol. $\% \mathrm{O}_{2}$ in $\mathrm{N}_{2}, 40,000 \mathrm{Ncm}^{3} /\left(\mathrm{h} \mathrm{g}_{\text {cat }}\right)$ & 558 & 23.66 & [77] \\
\hline $\mathrm{LaCuO}_{3}$ & 0.6 & \multirow{2}{*}{2 vol. $\% \mathrm{CH}_{4}$ in air, $45,000-5000 / \mathrm{h}$} & 672 & 23.8 & \multirow[t]{2}{*}{ [45] } \\
\hline $\mathrm{LaNiO}_{3}$ & 4.8 & & 702 & 19.4 & \\
\hline $\mathrm{LaNiO}_{3}$ & n.s. & 1.5 vol. $\% \mathrm{CH}_{4}, 4.2$ vol. $\% \mathrm{O}_{2}$ in $\mathrm{He}, 200 \mathrm{~cm}^{3} / \mathrm{min}, 0.004 \mathrm{~g}$ catalyst & n.s. & 79 & [3] \\
\hline $\mathrm{LaNiO}_{3}$ & 17.0 & 0.4 vol. $\% \mathrm{CH}_{4}, 2$ vol. $\% \mathrm{O}_{2}$ in $\mathrm{He}, 60,000 / \mathrm{h}, 1.5 \mathrm{~g}$ catalyst & $\sim 600$ & 18.7 & [51] \\
\hline $\mathrm{LaCrO}_{3}$ & 1.9 & 2 vol. $\% \mathrm{CH}_{4}$ in air, $45,000-5000 / \mathrm{h}$ & 780 & 28.8 & [45] \\
\hline $\mathrm{LaCrO}_{3}$ & n.s. & 1.5 vol. $\% \mathrm{CH}_{4}, 4.2$ vol. $\% \mathrm{O}_{2}$ in $\mathrm{He}, 200 \mathrm{~cm}^{3} / \mathrm{min}, 0.004 \mathrm{~g}$ catalyst & n.s. & 142 & [3] \\
\hline $\mathrm{LaCrO}_{3}$ & $\sim 5-7$ & $1.5 \mathrm{vol} . \%, 18 \mathrm{vol} . \%$ in $\mathrm{He}, 1.2 \mathrm{~cm}^{3} / \mathrm{s}$ & 692 & n.s. & [47] \\
\hline $\mathrm{LaRuO}_{3}$ & n.s. & 1.5 vol. $\% \mathrm{CH}_{4}, 4.2 \mathrm{vol} . \% \mathrm{O}_{2}$ in $\mathrm{He}, 200 \mathrm{~cm}^{3} / \mathrm{min}, 0.004 \mathrm{~g}$ catalyst & - & 95 & [3] \\
\hline $\mathrm{LaAlO}_{3}$ & 4.0 & 0.4 vol. $\% \mathrm{CH}_{4}, 10$ vol. $\% \mathrm{O}_{2}$ in $\mathrm{N}_{2}, 40,000 \mathrm{~cm}^{3} /\left(\mathrm{h} \mathrm{g}_{\text {cat }}\right), 0.4 \mathrm{~g}$ catalyst & $\sim 652$ & 28.1 & [55] \\
\hline $\mathrm{BaCeO}_{3}-\mathrm{ZrO}_{2}$ & 45.6 & \multirow{2}{*}{2 vol. $\% \mathrm{CH}_{4}, 16$ vol. $\% \mathrm{O}_{2}$ in $\mathrm{He}, 50 \mathrm{Ncm}^{3} / \mathrm{min}, 0.1 \mathrm{~g}$ catalyst } & 490 & n.s. & [82] \\
\hline $\mathrm{Pd} / \mathrm{BaCeO}_{3}-\mathrm{ZrO}_{2}$ & 26.4 & & 512 & n.s. & \multirow{3}{*}{ [44] } \\
\hline $\mathrm{BaTiO}_{3}$ & 0.4 & \multirow{2}{*}{5 vol. $\% \mathrm{CH}_{4}$ in air, $16,000 / \mathrm{h}$} & 744 & 85.8 & \\
\hline $\mathrm{PbTiO}_{3}$ & 0.5 & & 697 & 104.9 & \\
\hline
\end{tabular}

${ }^{\mathrm{a}} \mathrm{Ea}=$ activation energy; ${ }^{\mathrm{b}}$ n.s. - not specified.

The catalytic activity of the perovskites is strongly dependent on B-site cations, while A-site cations are responsible for structure stability, as already mentioned in Section 2.1. Therefore, by substituting small portions of A and/or B cations with other transition metals, both the catalytic activity and thermal/chemical stability of the final catalyst can be improved. Generally, the most used A-site dopants for perovskites are alkaline earth metals ( $\mathrm{Sr}$, Ca and Ba) $[3,45,53,58,61,71,73,74,76,78,79]$ and lanthanides (Ce, Eu) $[45,51,58,61,71]$, as can be observed in Table 10 where the performance of A-site doped perovskites in methane combustion is resumed. Arai et al. [45] reported that $\mathrm{La}_{0.6} \mathrm{Sr}_{0.4} \mathrm{MnO}_{3}$ perovskite prepared by solid state reaction exhibits similar catalytic activity to $\mathrm{Pt} / \mathrm{Al}_{2} \mathrm{O}_{3}$ at low temperatures $\left(350-550{ }^{\circ} \mathrm{C}\right)$. At temperatures higher than $600{ }^{\circ} \mathrm{C}$ it becomes less active than the noble metal catalyst. However, $\mathrm{La}_{0.6} \mathrm{Sr}_{0.4} \mathrm{MnO}_{3}$ was shown to be the most active catalyst compared to Ca-doped $\mathrm{LaMnO}_{3}$, Sr-doped $\mathrm{LaFeO}_{3}, \mathrm{Ba}$-doped $\mathrm{LaCoO}_{3}$, Ce-doped $\mathrm{LaCoO}_{3}$ and Ca-doped $\mathrm{LaCoO}_{3}$ [45]. The high activity of $\mathrm{La}_{0.6} \mathrm{Sr}_{0.4} \mathrm{MnO}_{3}$ for methane combustion at low temperatures was confirmed in other studies [71,74]. This behavior was correlated with its high capability to adsorb oxygen on the surface, most probably due to the fact that the presence of the bivalent dopant determines the formation of $\mathrm{Mn}^{4+}$ species, $[45,71,74]$. When the temperature increases, the amount of adsorbed oxygen decreases and, hence, its catalytic activity. Calcium is the most used element for $\mathrm{LaFeO}_{3}$ doping, as can be seen in Table 10. Pecchi et al. [76] reported a detailed study concerning $\mathrm{La}_{1-\mathrm{x}} \mathrm{Ca}_{\mathrm{x}} \mathrm{FeO}_{3}$ perovskites prepared by citrate and co-precipitation methods. For the samples prepared 
by co-precipitation, there are almost no changes in $T_{50}$ with the calcium content, while for those prepared via the citrate method the addition of calcium minimizes $\mathrm{T}_{50}$ [76]. Similar results on Ca-doped $\mathrm{LaFeO}_{3}$ prepared by the citrate method were also reported elsewhere [79].

Table 10. Performances of A-site-doped perovskite-type materials for the catalytic combustion of methane.

\begin{tabular}{|c|c|c|c|c|c|}
\hline Catalyst & SSA $\left(\mathrm{m}^{2} / \mathrm{g}\right)$ & Reaction Conditions & $\begin{array}{l}\mathrm{T}_{50} \\
\left({ }^{\circ} \mathrm{C}\right)\end{array}$ & $\begin{array}{c}E_{a} \\
(k J / m o l)\end{array}$ & Ref. \\
\hline $\mathrm{La}_{0.9} \mathrm{Sr}_{0.1} \mathrm{CoO}_{3}$ & 52 & 0.34 vol. $\% \mathrm{CH}_{4}, 33.3$ vol. $\%$ air in $\mathrm{He}, 30 \mathrm{Ncm}^{3} / \mathrm{min}, 0.15 \mathrm{~g}$ catalyst & 454 & n.s. ${ }^{b}$ & [61] \\
\hline $\mathrm{La}_{0.8} \mathrm{Sr}_{0.2} \mathrm{CoO}_{3}$ & 4.7 & 2 vol. $\% \mathrm{CH}_{4}$ in air, $45,000-5000 / \mathrm{h}$ & 518 & 21.3 & [45] \\
\hline $\mathrm{La}_{0.8} \mathrm{Sr}_{0.2} \mathrm{CoO}_{3}$ & 16.5 & $\begin{array}{c}4 \text { vol. } \% \mathrm{CH}_{4} \text { in air, } 4.2-5 \mathrm{~cm}^{3} / \mathrm{s} \\
1 \mathrm{~g} \text { catalyst }\end{array}$ & $640^{\mathrm{a}}$ & n.s. & [53] \\
\hline $\mathrm{La}_{0.75} \mathrm{Sr}_{0.25} \mathrm{CoO}_{3}$ & n.s. & 1.5 vol. $\% \mathrm{CH}_{4}, 4.2$ vol. $\% \mathrm{O}_{2}$ in $\mathrm{He}, 200 \mathrm{~cm}^{3} / \mathrm{min}, 0.004 \mathrm{~g}$ catalyst & n.s. & 81 & [3] \\
\hline $\mathrm{La}_{0.66} \mathrm{Sr}_{0.34} \mathrm{CoO}_{3}$ & 17.4 & $\begin{array}{c}4 \mathrm{vol} \% \mathrm{CH}_{4} \text { in air, } 4.2-5 \mathrm{~cm}^{3} / \mathrm{s} \\
1 \mathrm{~g} \text { catalyst }\end{array}$ & $675^{\mathrm{a}}$ & n.s. & [53] \\
\hline $\mathrm{La}_{0.6} \mathrm{Sr}_{0.4} \mathrm{CoO}_{3}$ & 3.6 & 2 vol. $\% \mathrm{CH}_{4}$ in air, $45,000-5000 / \mathrm{h}$ & 570 & 19.0 & [45] \\
\hline $\mathrm{La}_{0.5} \mathrm{Sr}_{0.5} \mathrm{CoO}_{3}$ & n.s. & 1.5 vol. $\% \mathrm{CH}_{4}, 4.2$ vol. $\% \mathrm{O}_{2}$ in $\left.\mathrm{He}\right), 200 \mathrm{~cm}^{3} / \mathrm{min}, 0.004 \mathrm{~g}$ catalyst & n.s. & 70 & [3] \\
\hline $\mathrm{La}_{0.8} \mathrm{Ba}_{0.2} \mathrm{CoO}_{3}$ & 5.1 & 2 vol. $\% \mathrm{CH}_{4}$ in air, $45,000-5000 / \mathrm{h}$ & 535 & 16.9 & [45] \\
\hline $\mathrm{La}_{0.8} \mathrm{Ca}_{0.2} \mathrm{CoO}_{3}$ & 2.0 & 2 Vol. $\% \mathrm{CH}_{4} \mathrm{in}$ all, $45,000-5000 / \mathrm{n}$ & 606 & 18.1 & \\
\hline $\mathrm{La}_{0.95} \mathrm{Ce}_{0.05} \mathrm{CoO}_{3}$ & 8.7 & 1 vol. $\% \mathrm{CH}_{4}$ in air, & 532 & 86 & [58] \\
\hline $\mathrm{La}_{0.9} \mathrm{Ce}_{0.1} \mathrm{CoO}_{3}$ & 10.0 & $45,000 \mathrm{~mL} /\left(\mathrm{h} \mathrm{g}_{\text {cat }}\right), 0.1 \mathrm{~g}$ catalyst & 515 & 83 & \\
\hline $\mathrm{La}_{0.9} \mathrm{Ce}_{0.1} \mathrm{CoO}_{3}$ & 62 & 0.34 vol. $\% \mathrm{CH}_{4}, 33.3$ vol. $\%$ air in $\mathrm{He}, 30 \mathrm{Ncm}^{3} / \mathrm{min}, 0.15 \mathrm{~g}$ catalyst & 447 & n.s. & [61] \\
\hline $\mathrm{La}_{0.8} \mathrm{Ce}_{0.2} \mathrm{CoO}_{3}$ & 3.1 & 2 vol. $\% \mathrm{CH}_{4}$ in air, $45,000-5000 / \mathrm{h}$ & 499 & 19.7 & [45] \\
\hline $\mathrm{La}_{0.8} \mathrm{Ce}_{0.2} \mathrm{CoO}_{3}$ & 14.2 & & 520 & 97 & [58] \\
\hline $\mathrm{La}_{0.7} \mathrm{Ce}_{0.3} \mathrm{CoO}_{3}$ & 14.3 & I vol. $\% \mathrm{CH}_{4}$ in air, & 505 & 81 & \\
\hline $\mathrm{La}_{0.6} \mathrm{Ce}_{0.4} \mathrm{CoO}_{3}$ & 11.6 & $40,000 \mathrm{~mL} /(\mathrm{n}$ gcat $), 0.1$ g catalyst & 530 & n.s. & \\
\hline $\mathrm{La}_{0.9} \mathrm{Sr}_{0.1} \mathrm{MnO}_{3}$ & 51 & 0.34 vol. $\% \mathrm{CH}_{4}, 33.3$ vol. $\%$ air in $\mathrm{He}, 30 \mathrm{Ncm}^{3} / \mathrm{min}, 0.15 \mathrm{~g}$ catalyst & 419 & n.s. & [61] \\
\hline $\mathrm{La}_{0.8} \mathrm{Sr}_{0.2} \mathrm{MnO}_{3}$ & 8.6 & 2 vol. $\% \mathrm{CH}_{4}$ in air, $45,000-5000 / \mathrm{h}$ & 510 & 19.7 & [45] \\
\hline $\mathrm{La}_{0.8} \mathrm{Sr}_{0.2} \mathrm{MnO}_{3}$ & 70 & 0.34 vol. $\% \mathrm{CH}_{4}, 33.3$ vol. $\%$ air in $\mathrm{He}, 30 \mathrm{Ncm}^{3} / \mathrm{min}, 0.15 \mathrm{~g}$ catalyst & 434 & n.s. & [61] \\
\hline $\mathrm{La}_{0.8} \mathrm{Sr}_{0.2} \mathrm{MnO}_{3+\mathrm{x}}$ & 5.0 & & 624 & 104 & [73] \\
\hline $\mathrm{La}_{0.8} \mathrm{Sr}_{0.2} \mathrm{MnO}_{3+\times} / \mathrm{MgAl}_{2} \mathrm{O}_{4}$ & 34.0 & & 619 & 92 & \\
\hline $\mathrm{La}_{0.8} \mathrm{Sr}_{0.2} \mathrm{MnO}_{3+\times} / \mathrm{NiAl}_{2} \mathrm{O}_{4}$ & 22.0 & 1 vol. $\% \mathrm{CH}_{4}, 4$ vol. $\% \mathrm{O}_{2}$ in $\mathrm{He}, 135,000 / \mathrm{h}$ & 642 & 98 & \\
\hline $\mathrm{La}_{0.8} \mathrm{Sr}_{0.2} \mathrm{MnO}_{3+\mathrm{x}} / \mathrm{CoAl}_{2} \mathrm{O}_{4}$ & 18.0 & & 707 & 114 & \\
\hline $\mathrm{La}_{0.75} \mathrm{Sr}_{0.25} \mathrm{MnO}_{3}$ & n.s. & 1.5 vol. $\% \mathrm{CH}_{4}, 4.2$ vol. $\% \mathrm{O}_{2}$ in $\left.\mathrm{He}\right), 200 \mathrm{~cm}^{3} / \mathrm{min}, 0.004 \mathrm{~g}$ catalyst & n.s. & 65 & [3] \\
\hline $\mathrm{La}_{0.6} \mathrm{Sr}_{0.4} \mathrm{MnO}_{3}$ & 3.3 & 2 vol. $\% \mathrm{CH}_{4}$ in air, $45,000-5000 / \mathrm{h}$ & 482 & 20.1 & [45] \\
\hline $\mathrm{La}_{0.6} \mathrm{Sr}_{0.4} \mathrm{MnO}_{3}$ & 18.7 & 0.5 vol. $\% \mathrm{CH}_{4}, 10$ vol. $\%$ air in $\mathrm{N}_{2}, 40 \mathrm{Ncm}^{3} / \mathrm{min}, 0.2 \mathrm{~g}$ catalyst & $\sim 470$ & n.s. & [71] \\
\hline $\mathrm{La}_{0.6} \mathrm{Sr}_{0.4} \mathrm{MnO}_{3}$ & 4.32 & & 480 & 136 & [74] \\
\hline $\mathrm{La}_{0.6} \mathrm{Sr}_{0.4} \mathrm{MnO}_{3}$ & 33.5 & 5 vol. $\% \mathrm{CH}_{4}, 30$ vol. $\% \mathrm{O}_{2}$ in $\mathrm{N}_{2}, 50,000 \mathrm{~cm}^{3} /\left(\mathrm{h} \mathrm{g}_{\text {cat }}\right), 0.05 \mathrm{~g}$ catalyst & 385 & 102 & \\
\hline $\mathrm{La}_{0.6} \mathrm{Sr}_{0.4} \mathrm{MnO}_{3}$ & 48.9 & & 360 & 67.3 & \\
\hline $\mathrm{La}_{0.5} \mathrm{Sr}_{0.5} \mathrm{MnO}_{3}$ & n.s. & 1.5 vol. $\% \mathrm{CH}_{4}, 4.2$ vol. $\% \mathrm{O}_{2}$ in $\left.\mathrm{He}\right), 200 \mathrm{~cm}^{3} / \mathrm{min}, 0.004 \mathrm{~g}$ catalyst & n.s. & 60 & [3] \\
\hline $\mathrm{La}_{0.8} \mathrm{Ca}_{0.2} \mathrm{MnO}_{3}$ & 6.7 & 2 vol. $\% \mathrm{CH}_{4}$ in air, $45,000-5000 / \mathrm{h}$ & 543 & 18.9 & [45] \\
\hline $\mathrm{La}_{0.9} \mathrm{Ce}_{0.1} \mathrm{MnO}_{3}$ & 32 & 0.5 vol. $\% \mathrm{CH}_{4}, 10$ vol. $\%$ air in $\mathrm{N}_{2}, 40 \mathrm{Ncm}^{3} / \mathrm{min}, 0.2 \mathrm{~g}$ catalyst & $\sim 440$ & n.s. & [71] \\
\hline $\mathrm{La}_{0.9} \mathrm{Ce}_{0.1} \mathrm{MnO}_{3}$ & 84 & 0.34 vol. $\% \mathrm{CH}_{4}, 33.3$ vol. $\%$ air in $\mathrm{He}, 30 \mathrm{Ncm}^{3} / \mathrm{min}, 0.15 \mathrm{~g}$ catalyst & 433 & n.s. & [61] \\
\hline$(\mathrm{La}-\mathrm{Ce}) \mathrm{MnO}_{3}$ & 19.0 & 0.4 vol. $\% \mathrm{CH}_{4}, 2$ vol. $\% \mathrm{O}_{2}$ in $\mathrm{He}, 60,000 / \mathrm{h}, 1.5 \mathrm{~g}$ catalyst & $\sim 730$ & 21 & [51] \\
\hline $\mathrm{La}_{0.9} \mathrm{Eu}_{0.1} \mathrm{MnO}_{3}$ & 26.4 & 0.5 vol. $\% \mathrm{CH}_{4}, 10$ vol. $\%$ air in $\mathrm{N}_{2}, 40 \mathrm{Ncm}^{3} / \mathrm{min}, 0.2 \mathrm{~g}$ catalyst & $\sim 425$ & n.s. & [71] \\
\hline $\mathrm{Sm}_{0.9} \mathrm{Sr}_{0.1} \mathrm{MnO}_{3}$ & 20.0 & 0.4 vol. $\% \mathrm{CH}_{4}, 10$ vol. $\% \mathrm{O}_{2}$ in $\mathrm{N}_{2}$ & $\sim 557$ & 20.8 & [72] \\
\hline $\mathrm{Sm}_{0.7} \mathrm{Sr}_{0.3} \mathrm{MnO}_{3}$ & 14.0 & & $\sim 527$ & 18.6 & \\
\hline$(\mathrm{Dy}-\mathrm{Y}) \mathrm{MnO}_{3}$ & 14.0 & 0.4 vol. $\% \mathrm{CH}_{4}, 2$ vol. $\% \mathrm{O}_{2}$ in $\mathrm{He}, 60,000 / \mathrm{h}, 1.5 \mathrm{~g}$ catalyst & $\sim 650$ & 25.2 & [51] \\
\hline $\begin{array}{l}\mathrm{La}_{0.95} \mathrm{Ag}_{0.05} \mathrm{MnO}_{3} / \\
\text { foil } \mathrm{Fe}_{2} \mathrm{Cr}_{20} \mathrm{Al}_{5}\end{array}$ & 27.4 & & n.s. & n.s. & [80] \\
\hline $\begin{array}{l}\mathrm{La}_{0.9} \mathrm{Ag}_{0.1} \mathrm{MnO}_{3} / \\
\text { foil } \mathrm{Fe}_{2} \mathrm{Cr}_{20} \mathrm{Al}_{5}\end{array}$ & 30.9 & $\begin{array}{c}1 \text { vol. } \% \mathrm{CH}_{4} \text { in air, } \\
64,410 \mathrm{~cm}^{3} /\left(\mathrm{h} \mathrm{g}_{\text {cat }}\right), 25.7 \mathrm{~g} \text { catalyst }\end{array}$ & n.s. & n.s. & \\
\hline $\begin{array}{l}\mathrm{La}_{0.8} \mathrm{Ag}_{0.2} \mathrm{MnO}_{3} / \\
\text { foil } \mathrm{Fe}_{2} \mathrm{Cr}_{20} \mathrm{Al}_{5}\end{array}$ & 29.4 & & 520 & n.s. & \\
\hline $\begin{array}{l}\mathrm{La}_{0.7} \mathrm{Ag}_{0.3} \mathrm{MnO}_{3} / \\
\text { foil } \mathrm{Fe}_{2} \mathrm{Cr}_{20} \mathrm{Al}_{5}\end{array}$ & 31.5 & & 528 & n.s. & \\
\hline $\mathrm{La}_{0.8} \mathrm{Sr}_{0.2} \mathrm{FeO}_{3}$ & 4.7 & 2 vol. $\% \mathrm{CH}_{4}$ in air, $45,000-5000 / \mathrm{h}$ & 542 & 17.8 & [45] \\
\hline$(\mathrm{La}-\mathrm{Ce}) \mathrm{FeO}_{3}$ & 5.3 & 0.4 vol. $\% \mathrm{CH}_{4}, 2$ vol. $\% \mathrm{O}_{2}$ in $\mathrm{He}, 60,000 / \mathrm{h}, 1.5 \mathrm{~g}$ catalyst & $\sim 700$ & 26.0 & [51] \\
\hline $\mathrm{La}_{0.9} \mathrm{Ca}_{0.1} \mathrm{FeO}_{3}$ & 6.0 & 0.4 vol. $\% \mathrm{CH}_{4}, 10$ vol. $\% \mathrm{O}_{2}$ in $\mathrm{N}_{2}, 40,000 \mathrm{Ncm}^{3} /\left(\mathrm{h} \mathrm{g}_{\text {cat }}\right), 0.4 \mathrm{~g}$ catalyst & 543 & 22.6 & [78] \\
\hline $\mathrm{La}_{0.9} \mathrm{Ca}_{0.1} \mathrm{FeO}_{3}$ & 14.0 & n.s. & 517 & n.s. & [76] \\
\hline $\mathrm{La}_{0.9} \mathrm{Ca}_{0.1} \mathrm{FeO}_{3}$ & 17.8 & & 505 & n.s. & \\
\hline $\mathrm{La}_{0.9} \mathrm{Ca}_{0.1} \mathrm{FeO}_{3}$ & 38.0 & 37,000 ppmv $\mathrm{CH}_{4}, 23.22$ vol. $\% \mathrm{O}_{2}$ in $\mathrm{He}$ & 508 & 97.9 & [79] \\
\hline $\mathrm{La}_{0.8} \mathrm{Ca}_{0.2} \mathrm{FeO}_{3}$ & 5.0 & 0.4 vol. $\% \mathrm{CH}_{4}, 10$ vol. $\% \mathrm{O}_{2}$ in $\mathrm{N}_{2}, 40,000 \mathrm{Ncm}^{3} /\left(\mathrm{h} \mathrm{g}_{\text {cat }}\right), 0.4 \mathrm{~g}$ catalyst & 537 & 22.6 & [78] \\
\hline $\mathrm{La}_{0.8} \mathrm{Ca}_{0.2} \mathrm{FeO}_{3}$ & 8.3 & n.s. & 530 & n.s. & [76] \\
\hline $\mathrm{La}_{0.8} \mathrm{Ca}_{0.2} \mathrm{FeO}_{3}$ & 38.6 & & 503 & n.s. & \\
\hline $\mathrm{La}_{0.8} \mathrm{Ca}_{0.2} \mathrm{FeO}_{3}$ & 38.0 & 37,000 ppmv $\mathrm{CH}_{4}, 23.22$ vol. $\% \mathrm{O}_{2}$ in $\mathrm{He}$ & 502 & 95.5 & [79] \\
\hline $\mathrm{La}_{0.7} \mathrm{Ca}_{0.3} \mathrm{FeO}_{3}$ & 3.0 & 0.4 vol. $\% \mathrm{CH}_{4}, 10$ vol. $\% \mathrm{O}_{2}$ in $\mathrm{N}_{2}, 40,000 \mathrm{Ncm}^{3} /\left(\mathrm{h} \mathrm{g}_{\text {cat }}\right), 0.4 \mathrm{~g}$ catalyst & 525 & 22.6 & [78] \\
\hline $\mathrm{La}_{0.7} \mathrm{Ca}_{0.3} \mathrm{FeO}_{3}$ & 5.4 & n.s. & 508 & n.s. & [76] \\
\hline $\mathrm{La}_{0.7} \mathrm{Ca}_{0.3} \mathrm{FeO}_{3}$ & 38.6 & & 505 & n.s. & \\
\hline $\mathrm{La}_{0.7} \mathrm{Ca}_{0.3} \mathrm{FeO}_{3}$ & 38.0 & 37,000 ppmv $\mathrm{CH}_{4}, 23.22$ vol. $\% \mathrm{O}_{2}$ in $\mathrm{He}$ & 494 & 94.9 & [79] \\
\hline $\mathrm{La}_{0.6} \mathrm{Ca}_{0.4} \mathrm{FeO}_{3}$ & 5.0 & 0.4 vol. $\% \mathrm{CH}_{4}, 10$ vol. $\% \mathrm{O}_{2}$ in $\mathrm{N}_{2}, 40,000 \mathrm{Ncm}^{3} /\left(\mathrm{h} \mathrm{g}_{\text {cat }}\right), 0.4 \mathrm{~g}$ catalyst & 541 & 22.6 & [78] \\
\hline $\mathrm{La}_{0.6} \mathrm{Ca}_{0.4} \mathrm{FeO}_{3}$ & 8.3 & n.s. & 511 & n.s. & [76] \\
\hline $\mathrm{La}_{0.6} \mathrm{Ca}_{0.4} \mathrm{FeO}_{3}$ & 31.2 & & 511 & n.s. & \\
\hline $\mathrm{La}_{0.6} \mathrm{Ca}_{0.4} \mathrm{FeO}_{3}$ & 33.0 & 37,000 ppmv $\mathrm{CH}_{4}, 23.22$ vol. $\% \mathrm{O}_{2}$ in $\mathrm{He}$ & 487 & 94.9 & [79] \\
\hline $\mathrm{La}_{0.5} \mathrm{Ca}_{0.5} \mathrm{FeO}_{3}$ & 0.7 & 0.4 vol. $\% \mathrm{CH}_{4}, 10$ vol. $\% \mathrm{O}_{2}$ in $\mathrm{N}_{2}, 40,000 \mathrm{Ncm}^{3} /\left(\mathrm{h} \mathrm{g}_{\text {cat }}\right), 0.4 \mathrm{~g}$ catalyst & 636 & 21.4 & [78] \\
\hline$(\mathrm{Dy}-\mathrm{Y}) \mathrm{FeO}_{3}$ & 8.6 & 0.4 vol. $\% \mathrm{CH}_{4}, 2$ vol. $\% \mathrm{O}_{2}$ in $\mathrm{He}, 60,000 / \mathrm{h}, 1.5 \mathrm{~g}$ catalyst & $\sim 750$ & 31.3 & [51] \\
\hline$(\mathrm{Dy}-\mathrm{Y}) \mathrm{NiO}_{3}$ & 9.5 & & $\sim 670$ & 28.4 & \\
\hline
\end{tabular}

${ }^{\mathrm{a}} \mathrm{T}_{100}$-the temperature corresponding to $100 \%$ methane conversion; ${ }^{\mathrm{b}}$ n.s. - not specified. 
In Table 11 the performances of B-doped perovskites in the catalytic combustion of methane are presented. Saracco et al. studied $\mathrm{LaCr}_{1-\mathrm{x}} \mathrm{Mg}_{\mathrm{x}} \mathrm{O}_{3}$ perovskite prepared by the citrate method and observed that its catalytic activity increases with the $\mathrm{Mg}$ content [47]. The opposite behaviour was observed for $\mathrm{LaAl}_{1-\mathrm{x}} \mathrm{Mn}_{\mathrm{x}} \mathrm{O}_{3}$, whose catalytic activity decreases with the $\mathrm{Al}$ content. $\mathrm{LaAl}_{0.2} \mathrm{Mn}_{0.8} \mathrm{O}_{3}$ shows the best activity, while the activity of $\mathrm{LaAl}_{0.4} \mathrm{Mn}_{0.6} \mathrm{O}_{3}$ is similar to the pure $\mathrm{LaMnO}_{3}$ [55]. A high fraction of $\mathrm{Fe}^{4+}$ is observed in $\mathrm{LaFe}_{1-\mathrm{x}} \mathrm{Mg}_{\mathrm{x}} \mathrm{O}_{3}$ perovskite and it increases with the addition of $\mathrm{Mg}$ content leading to lower catalytic activity at low temperatures [77]. Taguchi et al. [248] reported that $\mathrm{Ca}\left(\mathrm{Mn}_{0.6} \mathrm{Ti}_{0.4}\right) \mathrm{O}_{3}$ shows better catalytic activity compared to undoped $\mathrm{LaFeO}_{3}$ and $\left(\mathrm{La}_{0.8} \mathrm{Sr}_{0.2}\right)\left(\mathrm{Cu}_{0.15} \mathrm{Fe}_{0.85}\right) \mathrm{O}_{3}$ perovskites. In the case of $\mathrm{Ca}\left(\mathrm{Mn}_{0.6} \mathrm{Ti}_{0.4}\right) \mathrm{O}_{3}$ catalyst, the $\mathrm{T}_{50}$ value is ca. $580{ }^{\circ} \mathrm{C}$, while for $\mathrm{LaFeO}_{3}$ and $\left(\mathrm{La}_{0.8} \mathrm{Sr}_{0.2}\right)\left(\mathrm{Cu}_{0.15} \mathrm{Fe}_{0.85}\right) \mathrm{O}_{3}$ it increases up to 800 and $780{ }^{\circ} \mathrm{C}$, respectively. The significantly lower $\mathrm{T}_{50}$ value of the $\mathrm{Ca}\left(\mathrm{Mn}_{0.6} \mathrm{Ti}_{0.4}\right) \mathrm{O}_{3}$ system was attributed to the increased content of $\mathrm{Mn}^{3+}$ cations which act as oxygen adsorption sites $[78,248,249]$. Moreover, even a lower $\mathrm{T}_{50}$ value was reported for Al-doped $\mathrm{LaMnO}_{3}$. Thus, for $10 \% \mathrm{Al}^{3+}$ content, the $\mathrm{T}_{50}$ is ca. $520{ }^{\circ} \mathrm{C}$ and increases with the $\mathrm{Al}$ content. Notably, the $\mathrm{T}_{50}$ value decreases with the increase of the SSA, the highest SSA $\left(22 \mathrm{~m}^{2} / \mathrm{g}\right)$ corresponding to the $\mathrm{La}\left(\mathrm{Mn}_{0.9} \mathrm{Al}_{0.1}\right) \mathrm{O}_{3}$ system [250]. Recently, Miao et al. [251] reported a catalyst based on $\mathrm{La}(\mathrm{Mn}, \mathrm{Fe}) \mathrm{O}_{3}$ with an excellent stability at $550{ }^{\circ} \mathrm{C}$ in the catalytic combustion of methane. The methane conversion was almost entirely preserved after eight combustion cycles [251].

Table 11. Performances of B-site doped perovskite-type materials for the catalytic combustion of methane.

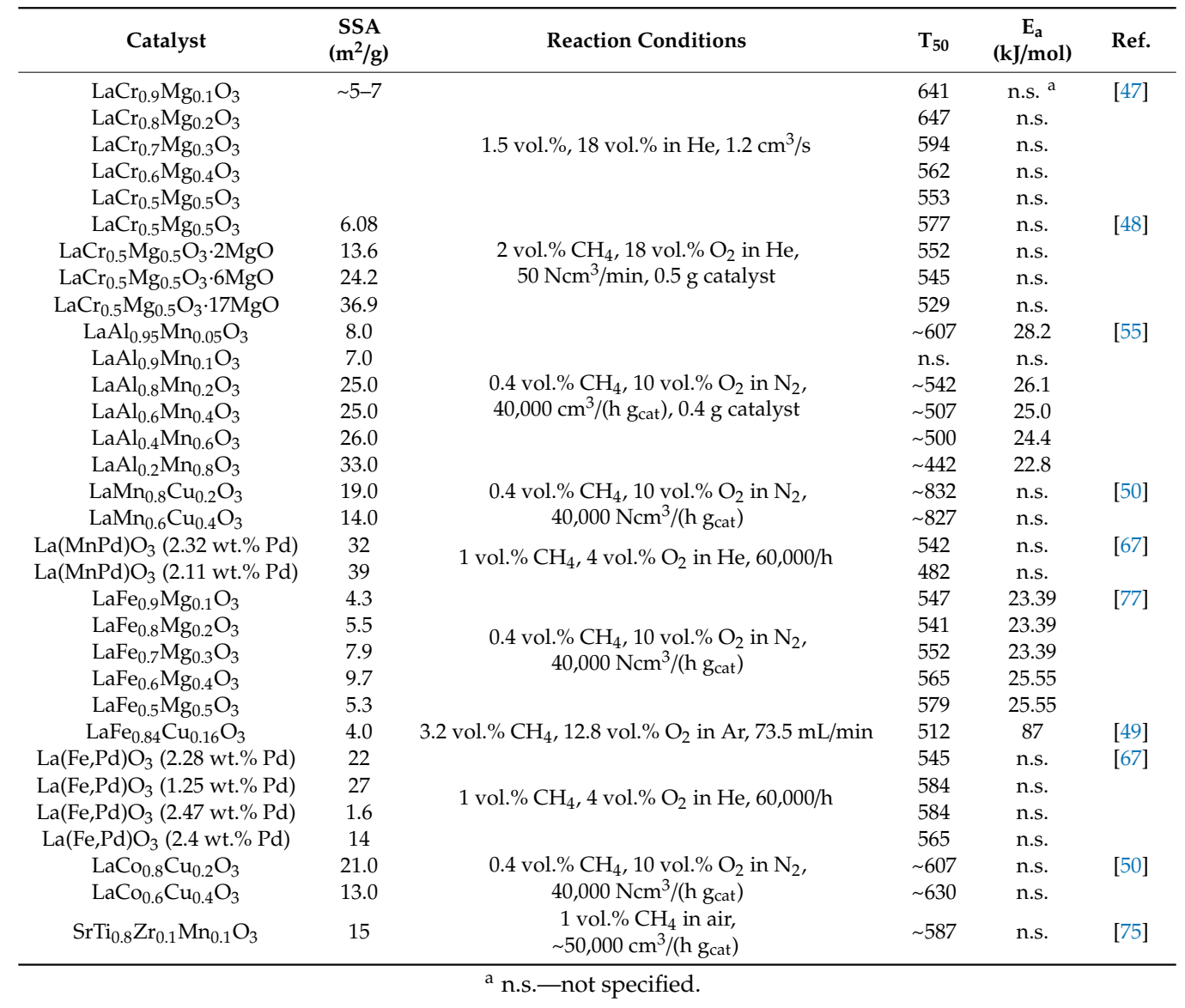

\subsection{Applications of Perovskite-Type Materials in the Removal of Pollutants from Waste Waters}

In the last few years, the high extent of pollution has become one of the biggest problems facing humanity because it can severely affect human life [252]. The residual dyes emerging from different industries (pharmaceutical, textile, paper and others) are considered to be the most common water 
pollutants. For example, in the textile industry, every kilogram of final product generates $50-100 \mathrm{~L}$ of waste water [253-255]. Numerous techniques for water treatment have already been developed, such as adsorption [256], chemical coagulation [257], electrocoagulation [258], advanced oxidation processes [259], photocatalysis [260] and photoelectrocatalysis [261]. The adsorption method used in waste water treatments involves the adhesion of pollutants (organic dyes, in this case) to the surface of a solid material, called adsorbent. The adsorbent properties of solid materials can be explained by the force fields which govern the surface properties. Depending on the type of forces established between the adsorbent and the adsorbed molecules, the adsorption can be: physical adsorption (for weak forces) and chemisorption (chemical bonds). The main characteristics controlling the adsorption efficiency of an adsorbent are the specific surface area and porosity. The adsorption method has the advantage that it can be used for a large amount of water with low pollutants content using simple and relatively cheap operating systems [262]. The most commonly used adsorbents for the elimination of organic dyes from water are: activated carbon [263,264], alumina [265,266], bentonite $[267,268]$ and zeolites [269]. The main drawbacks of these techniques are correlated to the adsorbents' capacity which decreases in time and the high costs of their regeneration. Moreover, depending on the pollutant's nature, the adsorbent could be irreversibly blocked [262]. Chemical coagulation is an extensively used method for the waste water treatment. It is based on the utilization of coagulants which have the ability to form precipitates. The pollutants are trapped in the formed precipitate which is settled, offering the possibility to easily separate the supernatant (water) from sediments. The process is strongly dependent on the $\mathrm{pH}$, coagulant concentration and mixing. Depending on the nature of the pollutant, the coagulant can be either inorganic $\left(\mathrm{AlCl}_{3} ; \mathrm{FeCl}_{3}\right)$ or organic (poly diallyldimethyl-ammonium chloride; polyacrylamide). This method is able to remove high amounts of organic dye from water, but it leads to an increased cost of the process due to two drawbacks: (i) it requires high quantities of chemical coagulant, and (ii) it produces large amounts of sludge $[270,271]$. The electrocoagulation is similar to the chemical coagulation, in this case the coagulants being electrochemically generated. It uses low-voltage and two sacrificial iron (or aluminum) electrodes. Under an applied current voltage, at anode are generated $\mathrm{Fe}^{3+}$ (or $\mathrm{Al}^{3+}$ ) species, while at cathode water is reduced to $\mathrm{H}_{2}$ and hydroxides. The ions formed at the anode surface react with hydroxide groups, leading to the coagulants' production. The resulting quantity of sludge is much lower compared to the chemical coagulation $[270,272]$. However, it requires often the replacement of the sacrificial electrodes to preserve a high efficiency. The operating cost of this technique increases significantly when applied in non-electrified areas, this being a common case for waste water found in nature [273]. One of the most used advanced oxidation methods for the degradation of dyes from waste water is ozonation. Ozone has a very high oxidation potential being capable to oxidize the organic dyes [259]. Unfortunately, ozone is very toxic for the human body, its strong oxidizing character can cause various diseases [274]. The photocatalytic and photoelectrochemical processes are considered to be the key solution to remove environmental pollution because they are clean methods which use renewable solar energy, their advantages have been already discussed in this review.

Rhodamine B is an important cationic xanthene dye being one of the mostly used model organic dye in photodegradation studies. Important quantities of this organic dye are coming from the textile industry contributing to environmental pollution [275-278]. Equally, methyl orange (anionic dye) and methylene blue (cationic dye) are considered harmful dyes released from textiles and printing industries and it is desired to minimise as much as possible their concentration in the environment [279-284]. Besides these, other common organic pollutants targeted in photodegradation applications are congo red (highly toxic and carcinogenic pollutant) [285], neutral red [286], phenol red [287], 4-methylphenol [288] and tetracycline [289], their chemical structures being presented in Table 12. 
Table 12. Chemical structures of some organic pollutants.

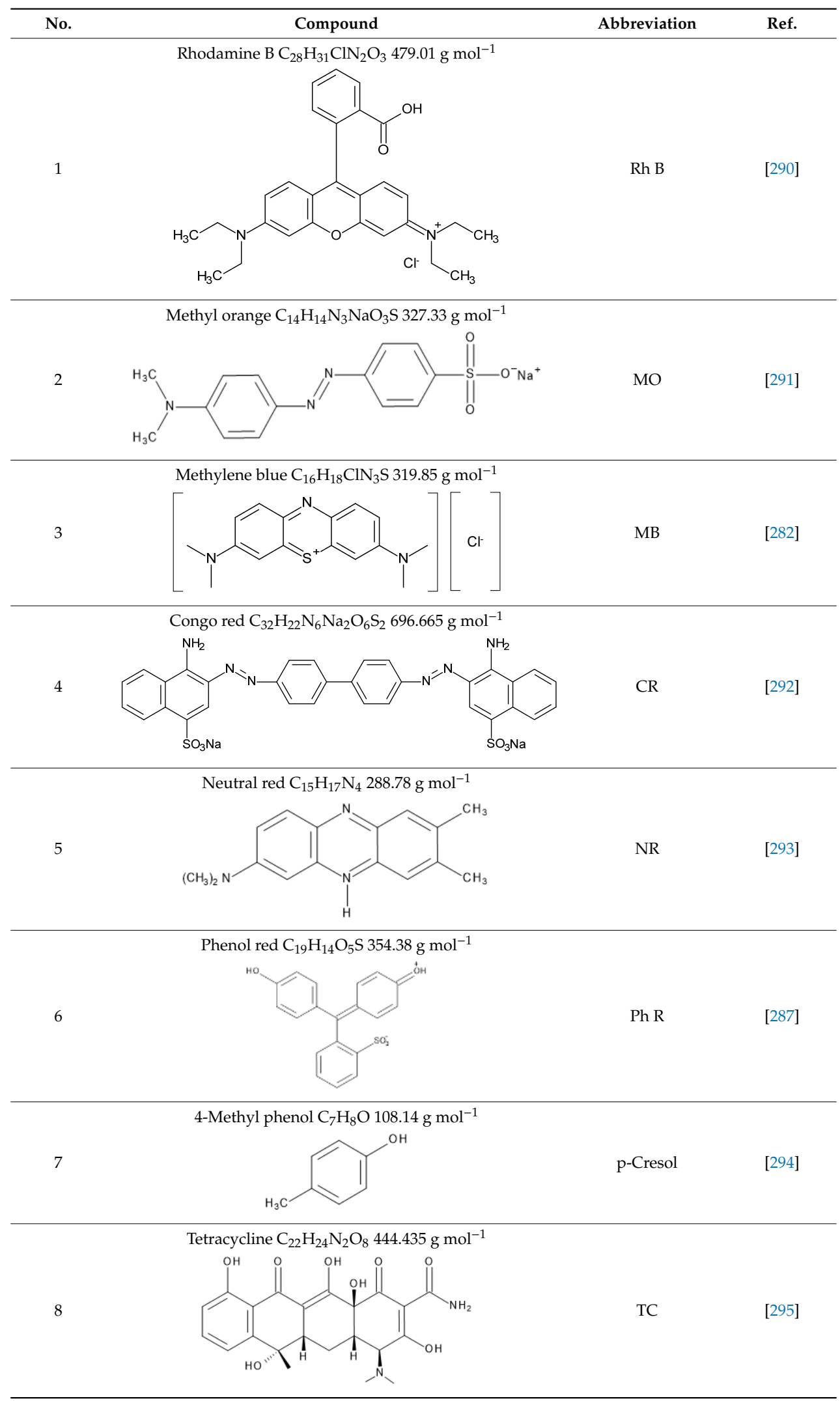

The photooxidation reaction of organic dyes is similar to the processes involved in the water-splitting reaction. When the semiconductor is irradiated, the photons having energies higher than its band 
gap energy are absorbed. The photogenerated charge carriers migrate to the photocatalyst surface. Once there, electrons react with adsorbed oxygen molecules $\left(\mathrm{O}_{2(\mathrm{ads})}\right)$ generating initially superoxide radicals $\left(\mathrm{O}_{2}{ }^{\bullet}\right)$ and, then, hydroperoxide radicals $\left(\mathrm{HOO}^{\bullet}\right)$. On the other hand, the positive holes interact with the surface-adsorbed water molecules $\left(\mathrm{H}_{2} \mathrm{O}_{(\text {ads })}\right)$ producing free hydroxyl radicals $\left(\mathrm{OH}^{\bullet}\right)$. When the organic compounds (dyes) are adsorbed on the photocatalyst surface, they are rapidly oxidized by the highly reactive radicals to $\mathrm{CO}_{2}$ and $\mathrm{H}_{2} \mathrm{O}$ [296]. The photodegradation of organic compounds can be schematically presented by the following series of reactions, where $\mathrm{P}=$ photocatalyst:

$$
\begin{aligned}
& \mathrm{P}+\mathrm{h} v \rightarrow \mathrm{P}\left(\mathrm{h}^{+}{ }_{\mathrm{VB}}\right)+\mathrm{P}\left(\mathrm{e}^{-}{ }_{\mathrm{CB}}\right) \\
& \mathrm{P}\left(\mathrm{h}^{+}{ }_{\mathrm{VB}}\right)+\mathrm{H}_{2} \mathrm{O}_{(\mathrm{ads})} \rightarrow \mathrm{P}+\mathrm{OH}^{\bullet}+\mathrm{H}^{+} \\
& \mathrm{OH}^{\bullet}+\text { organic dye } \rightarrow \mathrm{CO}_{2}+\mathrm{H}_{2} \mathrm{O} \\
& \mathrm{P}\left(\mathrm{e}^{-}{ }_{\mathrm{CB}}\right)+\mathrm{O}_{2(\mathrm{ads})} \rightarrow \mathrm{P}+\mathrm{O}_{2}{ }^{\bullet} \\
& \mathrm{O}_{2}^{\bullet}+\text { organic dye } \rightarrow \mathrm{CO}_{2}+\mathrm{H}_{2} \mathrm{O}
\end{aligned}
$$

As in the case of hydrogen production from water, $\mathrm{TiO}_{2}$ is the most utilized photocatalyst for water depollution. It was used as photocatalyst for organic dye photooxidation in both powder and immobilized form, with good photocatalytic activity [297-299]. Its activity was further improved when an external bias was applied to the system. However, pure $\mathrm{TiO}_{2}$ has high rate of the charge carrier's recombination and wide band gap value, which are the main drawbacks of this semiconductor in photocatalysis $[164,300]$.

Structural and compositional properties of oxide perovskites are suitable for the photodegradation of organic molecules, their performances being summarised in $\mathrm{Table}_{13} . \mathrm{SrTiO}_{3}$ shows excellent photocatalytic activity under UV irradiation for the degradation of rhodamine B [301,302] and methyl orange [303]. The rhodamine B was completely degraded after $1.3 \mathrm{~h}$, while $3 \mathrm{~h}$ were necessary to completely eliminate methyl orange dye. Under visible irradiation, the degradation efficiency of $\mathrm{SrTiO}_{3}$ is lower than $50 \%$, because of its large band gap [304].

The doping of $\mathrm{SrTiO}_{3}$ with different elements $(\mathrm{Fe}, \mathrm{Nb})$ leads to an improvement of the photocatalytic efficiency under visible light irradiation $[289,304,305] . \mathrm{LaCoO}_{3}$ shows even higher photocatalytic activity under UV irradiation for the degradation of rhodamine $\mathrm{B}$, with a complete photooxidation of the organic dye after $0.8 \mathrm{~h}$ [305]. Its activity considerably decreases under visible irradiation [306].

The degradation of methyl orange was performed with conversions higher than $90 \%$ over $\mathrm{BiFeO}_{3}$ photocatlaysts under both UV and visible light [307]. Moreover, nanoparticles of $\mathrm{BiFeO}_{3}$ and $\mathrm{Gd}$-doped $\mathrm{BiFeO}_{3}\left(\mathrm{Bi}_{1-\mathrm{x}} \mathrm{Gd}_{\mathrm{x}} \mathrm{O}_{3}\right.$, where $\left.x=0,0.05,0.1,0.15\right)$ prepared by classical citrate method were tested in the photodegradation of MB. It was observed that while increasing the Gd content, the photocatalytic activity increases as well, reaching the highest conversion of the organic dye (94\%) with $\mathrm{Bi}_{0.9} \mathrm{Gd}_{0.1} \mathrm{FeO}_{3}$. The increased ferromagnetic nature of $\mathrm{Bi}_{0.9} \mathrm{Gd}_{0.1} \mathrm{FeO}_{3}$ is considered responsible for its different photocatalytic behavior in $\mathrm{MB}$ degradation [308]. A similar degradation efficiency (94\%) was observed for rhodamine $\mathrm{B}$ over $\mathrm{Gd}$-doped $\mathrm{BiFeO}_{3}$ [309]. Congo red dye was almost completely oxidized on Ca-doped $\mathrm{BiFeO}_{3}$ ultrafine nanofibres $\left(\mathrm{Ca}_{x} \mathrm{Bi}_{1-x} \mathrm{FeO}_{3}\right.$, where $\left.x=0,0.05,0.1,0.15\right)$ and the photocatalytic conversion of the dye increased along with the Ca content [310]. $\mathrm{La}_{x} \mathrm{Bi}_{1-\mathrm{x}} \mathrm{FeO}_{3}(x=0$, $0.05,0.1,0.15)$ perovskites were used as photocatalysts for the photooxidation of the same dye, almost $80 \%$ of it being oxidized on $\mathrm{La}_{0.1} \mathrm{Bi}_{0.9} \mathrm{FeO}_{3}$ after $3 \mathrm{~h}$. Further increasing the La content decreases the conversion to ca. $50 \%$ [311].

A heterostructure based on $\mathrm{BiFeO}_{3} / \mathrm{CuWO}_{4}$ was tested for the degradation of methyl orange (MO) and rhodamine $\mathrm{B}(\mathrm{Rh} \mathrm{B})$. The dyes' concentrations were spectrometrically analyzed in time, and the absorption peaks of $\mathrm{MO}$ and Rh B disappeared almost entirely after 120 and 75 min, respectively. The higher photocatalytic activity observed on $\mathrm{BiFeO}_{3} / \mathrm{CuWO}_{4}$ compared to single components was correlated with the heterojunction formation between the two oxides. The most beneficial $\mathrm{BiFeO}_{3}: \mathrm{CuWO}_{4}$ ratio for the organic dyes photodegradation was found to be 1:1 [312]. Methyl violet 
(MV) was photooxidized up to $93 \%$ on a heterostructure based on p-n heterojunction $\mathrm{BiFeO}_{3} / \mathrm{TiO}_{2}$ under visible irradiation as an effect of the poor recombination of charge carriers and strong absorption properties of the device [313].

Great efficiencies were reported for pure $\mathrm{LaFeO}_{3}$ used as photocatalyst under visible irradiation for the degradation of 4-methylphenol [314], rhodamine B [315,316], and methyl orange [317]. Nanocubes, nanospheres and nanorods of $\mathrm{LaFeO}_{3}$ were used as photocatalysts for $\mathrm{Rh} \mathrm{B}$ oxidation under visible irradiation. No remarkable differences were observed between the nanorod and nanosphere morphologies, the organic dye conversions being similar. On the other hand, for the nanocube morphology the conversion efficiency was much lower. Irrespective of their morphology, all LFO samples showed better activities than Degusa P25 $\mathrm{TiO}_{2}$.

The higher efficiency of LFO is explained by its strong absorption properties in the visible region. Furthermore, the presence of an enhanced density of adsorbed oxygen or oxygen from surface hydroxyl groups on LFO photocatlaysts, which can act as efficient oxidizing agent, was confirmed by X-ray photoelectron spectroscopy (XPS) [318]. Wei et al. [319] reported that the doping of $\mathrm{LaFeO}_{3}$ with $\mathrm{Mn}$ ions leads to a perovskite structure of $\mathrm{LaFe}_{0.5} \mathrm{Mn}_{0.5} \mathrm{O}_{3}$ having higher oxygen vacancies and excellent absorption properties for visible light. All these, together with the variable valency of Mn cations contribute to the generation of a photocatalyst with improved activity for photodegradation of MO. It was also noted that the reaction mechanism is $\mathrm{pH}$-dependent: the global yield decreased with the increasing of the $\mathrm{pH}$ value [319]. Recently, numerous scientific papers based on a heterostructure of nanosheets of graphitic carbon nitride $\left(\mathrm{g}-\mathrm{C}_{3} \mathrm{~N}_{4}\right) / \mathrm{LFO}$ nanoparticles were reported. High values of the photogenerated current were obtained on $15 \% \mathrm{~g}-\mathrm{C}_{3} \mathrm{~N}_{4} / \mathrm{LFO}\left(\sim 9 \mu \mathrm{A} / \mathrm{cm}^{2}\right)$ and $20 \%$ g- $\mathrm{C}_{3} \mathrm{~N}_{4} / \mathrm{LFO}\left(\sim 17 \mu \mathrm{A} / \mathrm{cm}^{2}\right)$ compared to pristine LFO $\left(0.04 \mu \mathrm{A} / \mathrm{cm}^{2}\right)$. Rh B was almost completely oxidized on $\mathrm{g}-\mathrm{C}_{3} \mathrm{~N}_{4} / \mathrm{LFO}$ after ca. $2 \mathrm{~h}$ under visible light irradiation. Moreover, the photocatalytic device showed excellent stability, its activity being entirely maintained after 4 catalytic cycles [320,321]. This photocatalyst was also used with good results for Brilliant Blue (BB) degradation [322]. 
Table 13. The performances of complex oxides having perovskite-type structure in the photodegradation of organic dyes.

\begin{tabular}{|c|c|c|c|c|c|}
\hline $\begin{array}{l}\text { Photocatalyst/ } \\
\text { Photoelectrode }\end{array}$ & Dye & Light Source/Intensity & Experimental Conditions & Degradation Efficiency (\%) & Ref. \\
\hline $\mathrm{SrTiO}_{3}$ & Rhodamine B ( $\sim 5$ ppm) & $\begin{array}{l}\text { Ultraviolet (UV) light }(200-400 \mathrm{~nm}) / 3 \\
\times 15 \mathrm{~W} \text { tubes }\end{array}$ & $100 \mathrm{mg}$ photocatalyst; Irradiation time: $1.3 \mathrm{~h}$ & 100 & [301] \\
\hline $\mathrm{SrTiO}_{3}$ & Rhodamine B (5 ppm) & UV light/15 W & $226 \mathrm{mg} / \mathrm{L}$ photocatalyst; $20^{\circ} \mathrm{C}$; Irradiation: $4.5 \mathrm{~h}$ & 60 & [302] \\
\hline $\begin{array}{c}\mathrm{SrTiO}_{3} \\
\text { Fe-doped } \mathrm{SrTiO}_{3}\end{array}$ & Rhodamine B ( $\sim 5$ ppm) & Visible (Vis) light $(\lambda>420 \mathrm{~nm}) / 300 \mathrm{~W}$ & $100 \mathrm{mg}$ photocatalyst in $100 \mathrm{~mL}$; Irradiation time: $6 \mathrm{~h}$ & $\begin{array}{l}<50 \\
\sim 85\end{array}$ & [304] \\
\hline $\mathrm{Nb}$-doped $\mathrm{SrTiO}_{3}$ & Rhodamine B (10 ppm) & Vis light $(\lambda>420 \mathrm{~nm})$ & Irradiation time: $3 \mathrm{~h}$ & $\sim 50$ & [323] \\
\hline $\mathrm{KNbO}_{3}$ & Rhodamine B (40 ppm) & UV light $/ 300 \mathrm{~W}$ & $30 \mathrm{mg}$ photocatalyst in $200 \mathrm{~mL}$; Irradiation time: $4 \mathrm{~h}$ & 71 & [324] \\
\hline $\mathrm{NaNbO}_{3}$ & $\begin{array}{l}\text { Rhodamine B } \\
(2.5 \mathrm{ppm})\end{array}$ & UV light $/ 300 \mathrm{~W}$ & Irradiation time: $1 \mathrm{~h}$ & 72 & [325] \\
\hline $\mathrm{LaCoO}_{3}$ & $\begin{array}{l}\text { Rhodamine B } \\
\text { (2 ppm) }\end{array}$ & UV light/500 W & $10 \mathrm{mg}$ photocatalyst; $35^{\circ} \mathrm{C}$; Irradiation time: $0.8 \mathrm{~h}$ & $\sim 100$ & [305] \\
\hline $\begin{array}{l}\mathrm{GdFeO}_{3} \\
\mathrm{SmFeO}_{3}\end{array}$ & Rhodamine B (10 ppm) & Vis light $(\lambda>400 \mathrm{~nm}) / 150 \mathrm{~W}$ & $100 \mathrm{mg}$ photocatalyst in $100 \mathrm{~mL}$; Irradiation time: $3 \mathrm{~h}$ & $\begin{array}{l}\sim 90 \\
\sim 95\end{array}$ & [326] \\
\hline $\mathrm{BiFeO}_{3}$ & Rhodamine B (10 ppm) & Vis light/100W & 300 mg photocatalyst; Irradiation time: $3 \mathrm{~h}$ & $>30$ & [327] \\
\hline $\mathrm{BiFeO}_{3}$ & Rhodamine B ( $\sim 5 \mathrm{ppm})$ & Vis light $(\lambda>420 \mathrm{~nm}) / 500 \mathrm{~W}$ & $100 \mathrm{mg}$ photocatalyst in $50 \mathrm{~mL}$; Irradiation time: $6 \mathrm{~h}$ & 78 & [328] \\
\hline $\mathrm{BiFeO}_{3}$ & Rhodamine B (10 ppm) & Vis light $(\lambda>420 \mathrm{~nm}) / 300 \mathrm{~W}$ & $50 \mathrm{mg}$ photocatalyst in $50 \mathrm{~mL}$; Irradiation time: $6 \mathrm{~h}$ & $\sim 60$ & [329] \\
\hline Gd-doped $\mathrm{BiFeO}_{3}$ & Rhodamine B (5 ppm) & Vis light $(\lambda>420 \mathrm{~nm}) / 500 \mathrm{~W}$ & $40 \mathrm{mg}$ photocatalyst in $40 \mathrm{~mL}$; Irradiation time: $2 \mathrm{~h}$ & 94 & [309] \\
\hline $\mathrm{LaFeO}_{3}$ & Rhodamine B (1000 ppm) & Vis light $(\lambda>400 \mathrm{~nm}) / 150 \mathrm{~W}$ & $100 \mathrm{mg}$ photocatalyst in $100 \mathrm{~mL}$; Irradiation time: $3 \mathrm{~h}$ & 100 & [316] \\
\hline $\mathrm{LaFeO}_{3}$ & Rhodamine B (10 ppm) & Vis light $(\lambda>400 \mathrm{~nm}) / 150 \mathrm{~W}$ & $100 \mathrm{mg}$ photocatalyst in $100 \mathrm{~mL}$; Irradiation time: $3 \mathrm{~h}$ & $\sim 96$ & [326] \\
\hline $\mathrm{LaFeO}_{3}$ & Rhodamine B ( $\sim 5 \mathrm{ppm})$ & Vis light $(\lambda>400 \mathrm{~nm}) / 500 \mathrm{~W}$ & 10 mg photocatalyst; RT; Irradiation time: $2 \mathrm{~h}$ & 76 & [315] \\
\hline $\mathrm{LaFeO}_{3}$ & Rhodamine B (1000 ppm) & Vis light $(\lambda>400 \mathrm{~nm}) / 150 \mathrm{~W}$ & $100 \mathrm{mg}$ in $100 \mathrm{~mL}$; Irradiation time: $12 \mathrm{~h}$ & 93 & [316] \\
\hline $\mathrm{Ag} / \mathrm{LaFeO}_{3}$ & Rhodamine B (10 ppm) & UV Vis light/125 W & 100 mg photocatalyst; RT; Irradiation time: $2 \mathrm{~h}$ & 92.8 & [330] \\
\hline $\mathrm{SrTiO}_{3}$ & $\begin{array}{l}\text { Methyl orange } \\
(10 \mathrm{ppm})\end{array}$ & UV light/15 W & 75 mg photocatalyst; RT; Irradiation time: $3 \mathrm{~h}$ & 100 & [303] \\
\hline $\mathrm{Nb}$-doped $\mathrm{SrTiO}_{3}$ & $\begin{array}{l}\text { Methyl orange } \\
\text { (10 ppm) }\end{array}$ & Vis light $(\lambda>420 \mathrm{~nm})$ & Irradiation time: $3 \mathrm{~h}$ & $\sim 40$ & [323] \\
\hline $\mathrm{LaCoO}_{3}$ & $\begin{array}{l}\text { Methyl orange } \\
(100 \mathrm{ppm})\end{array}$ & Vis light & $100 \mathrm{mg}$ photocatalyst in $100 \mathrm{~mL}$; Irradiation time: $2 \mathrm{~h}$ & $\sim 60$ & [306] \\
\hline $\mathrm{LaCoO}_{3}$ & Methyl orange & UV light $/ 30 \mathrm{~W}$ & Irradiation time: $1.6 \mathrm{~h}$ & 89 & [331] \\
\hline $\mathrm{BiFeO}_{3}$ & $\begin{array}{l}\text { Methyl orange } \\
\text { (15 ppm) }\end{array}$ & UV-Vis light $/ 300 \mathrm{~W}$ & $30 \mathrm{mmol} / \mathrm{L}$ photocatalyst; Irradiation time: $8 \mathrm{~h}$ & $>90$ & [307] \\
\hline $\mathrm{BiFeO}_{3}$ & $\begin{array}{l}\text { Methyl orange } \\
(15 \mathrm{ppm})\end{array}$ & Vis light $/ 300 \mathrm{~W}$ & $30 \mathrm{mmol} / \mathrm{L}$ photocatalyst; Irradiation time: $16 \mathrm{~h}$ & $>90$ & [307] \\
\hline $\mathrm{BiFeO}_{3}$ & $\begin{array}{l}\text { Methyl orange } \\
(5 \mathrm{ppm})\end{array}$ & Vis light $(\lambda>420 \mathrm{~nm}) / 300 \mathrm{~W}$ & 200 mg photocatalyst; RT; Irradiation time: $4 \mathrm{~h}$ & $>30$ & {$[38]$} \\
\hline $\mathrm{LaFeO}_{3}$ & $\begin{array}{l}\text { Methyl orange } \\
(10 \mathrm{ppm})\end{array}$ & Vis light $(\lambda>420 \mathrm{~nm}) / 500 \mathrm{~W}$ & $\mathrm{RT}$; Irradiation time: $4 \mathrm{~h}$ & $>90$ & [317] \\
\hline $\mathrm{Nb}$-doped $\mathrm{SrTiO}_{3}$ & $\begin{array}{l}\text { Methylene blue } \\
\text { (10 ppm) }\end{array}$ & Vis light $(\lambda>420 \mathrm{~nm})$ & Irradiation time: $1.3 \mathrm{~h}$ & $\sim 85$ & [323] \\
\hline $\mathrm{KNbO}_{3}$ & $\begin{array}{l}\text { Methylene blue } \\
(\sim 13 \mathrm{ppm})\end{array}$ & Vis light $(\lambda>420 \mathrm{~nm}) / 180 \mathrm{~mW} / \mathrm{cm}^{2}$ & Irradiation time: $2 \mathrm{~h}$ & $\sim 50$ & [332] \\
\hline $\mathrm{NaNbO}_{3}$ & Methylene blue & UV light $(306 \mathrm{~nm}) / 1 \mathrm{~mW} / \mathrm{cm}^{2}$ & Irradiation time: $24 \mathrm{~h}$ & $\sim 15$ & [320] \\
\hline $\mathrm{LaCoO}_{3}$ & $\begin{array}{l}\text { Methylene blue } \\
\text { (10 ppm) }\end{array}$ & UV light $/ 30 \mathrm{~W}$ & 200 mg/L photocatalyst; Irradiation time: $1.6 \mathrm{~h}$ & 87 & [333] \\
\hline $\mathrm{SrFeO}_{3}$ & $\begin{array}{l}\text { Methylene blue } \\
(\sim 4 \mathrm{ppm})\end{array}$ & Vis light $/ 8 \mathrm{~W}$ & Irradiation time: $12 \mathrm{~h}$ & 100 & [321] \\
\hline
\end{tabular}


Table 13. Cont.

\begin{tabular}{|c|c|c|c|c|c|}
\hline $\begin{array}{l}\text { Photocatalyst/ } \\
\text { Photoelectrode }\end{array}$ & Dye & Light Source/Intensity & Experimental Conditions & Degradation Efficiency (\%) & Ref. \\
\hline $\mathrm{LaFeO}_{3}$ & $\begin{array}{l}\text { Methylene blue } \\
\text { (10 ppm) }\end{array}$ & Vis $\operatorname{light}(\lambda>420 \mathrm{~nm}) / 500 \mathrm{~W}$ & $\mathrm{RT}$; Irradiation time: $4 \mathrm{~h}$ & 93.8 & [317] \\
\hline Li-doped $\mathrm{LaFeO}_{3}$ & Methylene blue & UV Vis light $/ 250 \mathrm{~W}$ & $100 \mathrm{mg}$ photocatalyst in $50 \mathrm{~mL}$; Irradiation time: $1 \mathrm{~h}$ & 45.7 & [334] \\
\hline $\mathrm{BiFeO}_{3}$ & Congo red (20 ppm) & Vis light $(\lambda>420 \mathrm{~nm}) / 500 \mathrm{~W}$ & $2 \mathrm{~g} / \mathrm{L}$ photocatalyst; $\mathrm{RT}$; Irradiation time: $3 \mathrm{~h}$ & $\sim 40$ & [335] \\
\hline $\mathrm{SrTiO}_{3}$ & Rhodamine B ( $\sim$ ppm) & $\begin{array}{l}\text { Ultraviolet (UV) light }(200-400 \mathrm{~nm}) / 3 \\
\times 15 \mathrm{~W} \text { tubes }\end{array}$ & 100 mg photocatalyst; Irradiation time: $1.3 \mathrm{~h}$ & 100 & [301] \\
\hline $\mathrm{BiFeO}_{3}$ & Congo red (10 ppm) & Vis light $(\lambda>400 \mathrm{~nm}) / 500 \mathrm{~W}$ & $\mathrm{RT}$; Irradiation time: $4 \mathrm{~h}$ & $\sim 15$ & [336] \\
\hline Ba-doped $\mathrm{BiFeO}_{3}$ & Congo red (100 ppm) & $\begin{array}{l}\text { Vis light } / 500 \mathrm{~W} \\
\text { W }\end{array}$ & Irradiation time: $120 \mathrm{~min}$ & $\sim 30$ & [337] \\
\hline $\mathrm{Mn}$-doped $\mathrm{BiFeO}_{3}$ & Congo red & Vis light $(\lambda>400 \mathrm{~nm}) / 500 \mathrm{~W}$ & $\mathrm{RT}$; Irradiation time: $2 \mathrm{~h}$ & $\sim 40$ & [338] \\
\hline $\mathrm{LaCoO}_{3}$ & Neutral red & UV light $/ 30 \mathrm{~W}$ & Irradiation time: $0.6 \mathrm{~h}$ & 88 & [331] \\
\hline La-doped $\mathrm{BiFeO}_{3}$ & Phenol red (3.5 ppm) & Vis light $(\lambda>400 \mathrm{~nm}) / 300 \mathrm{~W}$ & 100 mg photocatalyst; RT; Irradiation time: $2 \mathrm{~h}$ & 90.1 & [333] \\
\hline $\mathrm{LaFeO}_{3}$ & $\begin{array}{l}\text { 4-methyphenol } \\
\text { (10 ppm) }\end{array}$ & Vis light $/ 1500 \mathrm{~W}$ & $\begin{array}{l}1200 \mathrm{mg} \text { photocatalyst; } \\
\text { Irradiation time: } 6 \mathrm{~h}\end{array}$ & $>90$ & [314] \\
\hline $\mathrm{Ca}$-doped $\mathrm{LaFeO}_{3}$ & & & & $\sim 70$ & \\
\hline Fe-doped $\mathrm{SrTiO}_{3}$ & $\begin{array}{l}\text { Tetracycline } \\
(10 \mathrm{ppm})\end{array}$ & Vis light $(\lambda>420 \mathrm{~nm}) / 300 \mathrm{~W}$ & $100 \mathrm{mg}$ photocatalyst in $100 \mathrm{~mL}$; Irradiation time: $1.3 \mathrm{~h}$ & $\sim 71.6$ & [289] \\
\hline
\end{tabular}




\section{Conclusions and Perspectives}

The properties and (photo)catalytic behavior of perovskite materials in water splitting, catalytic combustion of methane and photo-degradation of pollutants from water have been presented and discussed based on more than 300 relevant papers, leading to the following conclusions:

> There are various synthesis methods for both powder and thin films, which determine their physicochemical properties. The specific surface area of the perovskite powders, which is a key characteristic of a solid catalyst, is strongly influenced by the preparation method used, but remains low. Indeed, the highest surface areas, mainly obtained by citrate and flame-pyrolysis methods, do not exceed several tens of $\mathrm{m}^{2} / \mathrm{g}$. On the other hand, pulsed laser deposition is one of the most suitable preparation methods for inorganic perovskite thin films, due to its high material transfer efficiency, precise control and the great flexibility of the process. Depending on the experimental conditions, the stoichiometry of the material, as well as the thickness and the crystallinity of the films can be controlled. The most commonly used lasers for the preparation of perovskite films are those emitting in UV spectrum $(193 \mathrm{~nm}, 248 \mathrm{~nm}$ and $355 \mathrm{~nm})$. The films' thickness starts from less than $1 \mathrm{~nm}$ and rises up to ca. $600 \mathrm{~nm}$.

$>$ Oxide ferroelectric perovskites show excellent efficiency for the conversion of solar energy into chemical energy $\left(\mathrm{H}_{2}\right)$ via water splitting. Both photocatalytic and photoelectrochemical systems are extensively studied in this application domain. The high spontaneous polarization of $\mathrm{BiFeO}_{3}$ is beneficial for a very efficient electron-hole separation. $\mathrm{LaFeO}_{3}$ presents strong absorption properties of visible light, which represents ca. $42 \%$ of the entire solar spectrum. The photoelectrodes are tested for a wide range of $\mathrm{pH}$ values, starting from semi-acidic to strong alkaline media. The highest photocurrent density $\left(46.9 \mathrm{~mA} / \mathrm{cm}^{2}\right.$ at $\left.2.53 \mathrm{~V}_{\mathrm{RHE}}\right)$ is obtained for a complex heterostructure based on $\mathrm{WO}_{3} / \mathrm{BiBO}_{4} / \mathrm{BiFeO}_{3}$. The best stability (more than $120 \mathrm{~h}$ ) was reported in $1 \mathrm{M} \mathrm{NaOH}$ for $\mathrm{p}-\mathrm{LaFeO}_{3} / \mathrm{n}-\mathrm{Fe}_{2} \mathrm{O}_{3}$.

$>$ Due to their good thermal stability, perovskite materials were successfully used in the catalytic combustion of methane for both power generation and methane emission abatement. Although the performance of pure perovskites is limited by their small specific surface area, their efficiency can be improved either by dispersion onto support materials possessing high surface area and thermal stability or by doping with other transition metals. Indeed, substitution in A and B sites of the perovskite structure with small amounts of other cations can improve both the stability and activity of the catalyst. Improved activity and stability can also be obtained by coating of the supported perovskite either on ceramic or metallic monoliths. The most used A-site dopants for perovskites are alkaline earth metals $(\mathrm{Sr}, \mathrm{Ca}$ and $\mathrm{Ba})$ and lanthanides $(\mathrm{Ce}, \mathrm{Eu})$, while for $\mathrm{B}$-sites metals from the 3 and 4 periods $(\mathrm{Mg}, \mathrm{Al}, \mathrm{Mn}$ and $\mathrm{Cu})$ in particular are preferred. The most active perovskites for the low-pressure methane combustion is $\mathrm{La}_{0.6} \mathrm{Sr}_{0.4} \mathrm{MnO}_{3}$ with a value of $\mathrm{T}_{50 \%}$ of $360^{\circ} \mathrm{C}$. The high activity of this catalyst is due to its enhanced ability to adsorb oxygen on the surface.

$>$ The photodegradation of organic dyes on inorganic semiconducting perovskites showed excellent results. Their high stability under extreme chemical conditions, strong absorption properties and efficient charge separation lead to high photocatalytic activity even after several reaction cycles. Catalytic systems containing $\mathrm{BiFeO}_{3}$ perovskites as such or modified with different dopants exhibited an exceptionally high activity in the photocatalytic degradation of both anionic and cationic organic dyes.

Due to their high chemical and thermal stabilities together with their large compositional flexibility, perovskites remain (photo)catalytic materials of choice for applications in energy production and environmental protection. Obviously, new preparation procedures and the improvement of existing ones will allow in the future not only higher surface areas to be obtained but also new morphologies with consequences for their (photo)catalytic behavior. 
Author Contributions: Conceptualization, R.Z. and I.-C.M.; writing-original draft preparation, F.A.; writing-review and editing, R.Z. and I.-C.M.; visualization, F.A.; supervision, I.-C.M. All authors have read and agreed to the published version of the manuscript.

Funding: This research received no external funding.

Conflicts of Interest: The authors declare no conflict of interest.

\section{References}

1. Libby, W.F. Promising catalyst for auto exhaust. Science 1971, 171, 499-500. [CrossRef]

2. Pedersen, L.A.; Libby, W.F. Unseparated rare earth cobalt oxides as auto exhaust catalysts. Science 1972, 176, 1355-1356. [CrossRef]

3. McCartyt, J.G.; Wise, H. Perovskite catalysts for methane combustion. Catal. Today 1990, 8, 231-248. [CrossRef]

4. Ladavos, A.K.; Pornonis, P.J. Catalytic combustion of methane on $\mathrm{La}_{2-\mathrm{x}} \mathrm{Sr}_{\mathrm{x}} \mathrm{NiO}_{4-\lambda}(\mathrm{x}=0.00-1.50)$ Perovskites prepared via the nitrate and citrate routes. J. Chem. Soc. Faraday Trans. 1992, 88, 2557-2562. [CrossRef]

5. Li, X.; Liu, Y.; Deng, J.; Xie, S.; Zhao, X.; Zhang, Y.; Zhang, K.; Arandiyan, H.; Guo, G.; Dai, H. Enhanced catalytic performance for methane combustion of $3 \mathrm{DOM} \mathrm{CoFe} 2 \mathrm{O}_{4}$ by co-loading $\mathrm{MnO}_{\mathrm{x}}$ and $\mathrm{Pd}-\mathrm{Pt}$ alloy nanoparticles. Appl. Surf. Sci. 2017, 403, 590-600. [CrossRef]

6. Rajeshwar, K. Hydrogen generation at irradiated oxide semiconductor-solution interfaces. J. Appl. Electrochem. 2007, 37, 765-787. [CrossRef]

7. Wang, W.; Tade, M.O.; Shao, Z. Research progress of perovskite materials in photocatalysis- and photovoltaics-related energy conversion and environmental treatment. Chem. Soc. Rev. 2015, 44, 5371-5408. [CrossRef] [PubMed]

8. Ladavos, A.; Pomonis, P. Methane Combustion on Perovskites. In Perovskites and Related Mixed Oxides; Granger, P., Parvulescu, V.I., Kaliaguine, S., Prellier, W., Eds.; Wiley: Weinheim, Germany, 2016; pp. 367-388.

9. Megaw, H.D. Crystal structure of double oxides of the perovskite type. Proc. Phys. Soc. 1946, 58, 340. [CrossRef]

10. Galasso, F.S. Structure of Perovskite-Type Compounds. In Structure, Properties and Preparation of Perovskite-Type Compounds, 1st ed.; Smoluchowski, R., Kurti, N., Eds.; Elsevier Pergamon Press Inc.: Oxford, UK, 1969; pp. 2-49.

11. Goldschmidt, V.M. Die gesetze der krystallochemie. Naturwissenschaften 1926, 14, 477-485. [CrossRef]

12. Pena, M.A.; Fierro, J.L.G. Chemical structures and performance of perovskite oxides. Chem. Rev. 2001, 101, 1981-2017. [CrossRef]

13. Bhalla, A.S.; Guo, R.; Roy, R. The perovskite structure-A review of its role in ceramic science and technology. Mater. Res. Innov. 2000, 4, 3-26. [CrossRef]

14. Poglitsch, A.; Weber, D. Dynamic disorder in methylammoniumtrihalogenoplumbates (II) observed by millimeter-wave spectroscopy. J. Chem. Phys. 1987, 87, 6373-6378. [CrossRef]

15. Li, W.; Wang, Z.; Deschler, F.; Gao, S.; Friend, R.H.; Cheetham, A.K. Chemically diverse and multifunctional hybrid organic-inorganic perovskites. Nat. Rev. Mater. 2017, 2, 1-18. [CrossRef]

16. Weber, D. $\mathrm{CH}_{3} \mathrm{NH}_{3} \mathrm{PbX}_{3}$, a $\mathrm{Pb}$ (II)-system with cubic perovskite structure. J. Chem. Sci. B 1978, 33, 1443-1445. [CrossRef]

17. Kieslich, G.; Sun, S.; Cheetham, A.K. An extended tolerance factor approach for organic-inorganic perovskites. Chem. Sci. 2015, 6, 3430-3433. [CrossRef] [PubMed]

18. Chen, J.C.; Wu, J.M. Dielectric properties and ac conductivities of dense single-phased $\mathrm{BiFeO}_{3}$ ceramics. Appl. Phys. Lett. 2007, 91, 182903. [CrossRef]

19. Nakayam, S. $\mathrm{LaFeO}_{3}$ perovskite-type oxide prepared by oxide-mixing, co-precipitation and complex synthesis methods. J. Mater. Sci. 2001, 36, 5643-5648. [CrossRef]

20. Muneeswaran, M.; Jegatheesan, P.; Giridharan, N.V. Synthesis of nanosized $\mathrm{BiFeO}_{3}$ powders by co-precipitation method. J. Exp. Nanosci. 2012, 8, 341-346. [CrossRef]

21. Dhakad, M.; Rayalu, S.S.; Kumar, R.; Doggali, P.; Bakardjieva, S.; Subrt, J.; Mitsuhashi, T.; Haneda, H.; Labhsetwar, N. Low cost, ceria promoted perovskite type catalysts for diesel soot oxidation. Catal. Lett. 2008, 121, 137-143. [CrossRef]

22. Huang, F.; Sun, X.; Zheng, Y.; Xiao, Y.; Zheng, Y. Facile coprecipitation synthesis of $\mathrm{La}_{0.6} \mathrm{Sr}_{0.4} \mathrm{MnO}_{3}$ perovskites with high surface area. Mater. Lett. 2017, 210, 287-290. [CrossRef] 
23. Gosavi, P.V.; Biniwale, R.B. Pure phase $\mathrm{LaFeO}_{3}$ perovskite with improved surface area synthesized using different routes and its characterization. Mater. Chem. Phys. 2010, 119, 324-329. [CrossRef]

24. Delmon, B.; Devillers, M. Solid State Reactions. In Handbook of Heterogeneous Catalysis, 2nd ed.; Ertl, G., Knozinger, H., Schuth, F., Weitkamp, J., Eds.; Wiley: Weinheim, Germany, 2008; pp. 295-318.

25. Esposito, S. "Traditional" sol-gel chemistry as a powerful tool for the preparation of supported metal and metal oxide catalysts. Materials 2019, 12, 668. [CrossRef] [PubMed]

26. Shu, J.; Kaliaguine, S. Well-dispersed perovskite-type oxidation catalysts. Appl. Catal. B 1998, 16, $303-308$. [CrossRef]

27. Rida, K.; Benabbas, A.; Bouremmad, F.; Pen, M.A.; Sastre, E.; Martınez-Arias, A. Effect of calcination temperature on the structural characteristics and catalytic activity for propene combustion of sol-gel derived lanthanum chromite perovskite. Appl. Catal. A 2007, 327, 173-179. [CrossRef]

28. Zhong, Z.; Chen, L.; Yan, Q.; Fu, X. Study on the preparation of nanometer perovskite-type complex oxide $\mathrm{LaFeO}_{3}$ by sol-gel method. Stud. Surf. Sci. Catal. 1995, 91, 647-655. [CrossRef]

29. Wei, J.; Xue, D. Low-temperature synthesis of $\mathrm{BiFeO}_{3}$ nanoparticles by ethylenediaminetetraacetic acid complexing sol-gel process. Mater. Res. Bull. 2008, 43, 3368-3373. [CrossRef]

30. Ghosh, S.; Dasgupta, S.; Sen, A.; Maiti, H.S. Low temperature synthesis of bismuth ferrite nanoparticles by a ferrioxalate precursor method. Mater. Res. Bull. 2005, 40, 2073-2079. [CrossRef]

31. Wang, X.; Zhang, Y.; Wu, Z. Magnetic and optical properties of multiferroic bismuth ferrite nanoparticles by tartaric acid-assisted sol-gel strategy. Mater. Lett. 2010, 64, 486-488. [CrossRef]

32. Liu, T.; Xu, Y. Synthesis of nanocrystalline $\mathrm{LaFeO}_{3}$ powders via glucose sol-gel route. Mater. Chem. Phys. 2011, 129, 1047-1050. [CrossRef]

33. Dhal, G.; Dey, S.; Mohan, D.; Prasa, R. Solution combustion synthesis of perovskite-type catalysts for diesel engine exhaust gas purification. Mater. Today Proc. 2017, 4, 10489-10493. [CrossRef]

34. Peñalva, J.; Lazo, A. Synthesis of bismuth ferrite $\mathrm{BiFeO}_{3}$ by solution combustion method. In Journal of Physics: Conference Series, Proceedings of the XVI Meeting of Physics, Lima, Peru, 2-4 August 2017; Ochoa, R., Salinas, E., Blas, H., Eds.; IOP Publishing: Bristol, UK, 2017; pp. 195-202.

35. Biamino, S.; Badini, C. Combustion synthesis of lanthanum chromite starting from water solutions: Investigation of process mechanism by DTA-TGA-MS. J. Eur. Ceram. Soc. 2004, 24, 3021-3034. [CrossRef]

36. Russo, N.; Fino, D.; Saracco, G.; Specchia, V. Promotion effect of Au on perovskite catalysts for the regeneration of diesel particulate filters. Catal. Today. 2008, 137, 306-311. [CrossRef]

37. Shandilya, M.; Rai, R.; Singh, J. Review: Hydrothermal technology for smart materials. Appl. Ceram. 2016, 115, 354-376. [CrossRef]

38. Niu, F.; Gao, T.; Zhang, N.; Chen, Z.; Huang, Q.; Qin, L.; Sun, X.; Huang, Y. Hydrothermal synthesis of $\mathrm{BiFeO}_{3}$ nanoparticles for visible light photocatalytic applications. Mater. Res. Bull. 2014, 59, 6-12. [CrossRef]

39. Zheng, W.; Liu, R.; Peng, D.; Meng, G. Hydrothermal synthesis of $\mathrm{LaFeO}_{3}$ under carbonate-containing medium. Mater. Lett. 2000, 43, 19-22. [CrossRef]

40. Assirey, E.A.R. Perovskite synthesis, properties and their related biochemical and industrial application. Saudi Pharm. J. 2019, 27, 817-829. [CrossRef]

41. Perejón, A.; Murafa, N.; Sánchez-Jiménez, P.E.; Criado, J.M.; Subrt, J.; Diánez, M.J.; Pérez-Maqued, L.A. Direct mechanosynthesis of pure $\mathrm{BiFeO}_{3}$ perovskite nanoparticles: Reaction mechanism. J. Mater. Chem. C 2013, 1, 3551-3562. [CrossRef]

42. Sorescu, M.; Xu, T.; Burnett, J.D.; Aitken, J.A. Investigation of $\mathrm{LaFeO}_{3}$ perovskite growth mechanism through mechanical ball milling of lanthanum and iron oxides. J. Mater. Sci. 2011, 46, 6709-6717. [CrossRef]

43. Amador, C.; Martin de Juan, L. Strategies for structured particulate systems design. Comput. Aided Chem. Eng. 2016, 39, 509-579. [CrossRef]

44. Popescu, I.; Sandulescu, I.; Redey, A.; Marcu, I.C. Study of the catalytic activity-semiconductive properties relationship for $\mathrm{BaTiO}_{3}$ and $\mathrm{PbTiO}_{3}$ perovskites, catalysts for methane combustion. Catal. Lett. 2011, 141, 445-451. [CrossRef]

45. Arai, H.; Yamada, T.; Eguchi, K.; Seiyama, T. Catalytic combustion of methane over various perovskite-type oxides. Appl. Catal. 1986, 26, 265-276. [CrossRef]

46. Majid, A.; Tunney, J.; Argue, S.; Post, M. The effect of preparation method and calcination temperature on the crystallite size and surface area of perovskite-type SrFeOx. J. Sol Gel Sci. Technol. 2004, 32, 323-326. [CrossRef] 
47. Saracco, G.; Scibilia, G.; Iannibello, A.; Baldi, G. Methane combustion on Mg-doped LaCrO, perovskite catalysts. Appl. Catal. B 1996, 8, 229-244. [CrossRef]

48. Rosso, I.; Saracco, G.; Specchia, V.; Garrone, E. Sulphur poisoning of $\mathrm{LaCr}_{0.5-\mathrm{x}} \mathrm{Mn}_{\mathrm{x}} \mathrm{Mg}_{0.5} \mathrm{O}_{3} \cdot \mathrm{yMgO}$ catalysts for methane combustion. Appl. Catal. B 2003, 40, 195-205. [CrossRef]

49. Salomonsson, P.; Griffin, T.; Kasemo, B. Oxygen desorption and oxidation-reduction kinetics with methane and carbon monoxide over perovskite type metal oxide catalysts. Appl. Catal. A 1993, 194, 175-197. [CrossRef]

50. Lisi, L.; Bagnasco, G.; Ciambelli, P.; De Rossi, S.; Porta, P.; Russo, G.; Turco, M. Perovskite-type oxides, II. Redox properties of $\mathrm{LaMn}_{1-\mathrm{x}} \mathrm{Cu}_{\mathrm{x}} \mathrm{O}_{3}$ and $\mathrm{LaCo}_{1-\mathrm{x}} \mathrm{Cu}_{\mathrm{x}} \mathrm{O}_{3}$ and methane catalytic combustion. J. Solid State Chem. 1999, 146, 176-183. [CrossRef]

51. Ciambellia, P.; Palma, V.; Tikhov, S.F.; Sadykov, V.A.; Isupova, L.A.; Lisi, L. Catalytic activity of powder and monolith perovskites in methane combustion. Catal. Today 1999, 47, 199-207. [CrossRef]

52. Alifanti, M.; Kirchnerova, J.; Delmon, B.; Klvana, D. Methane and propane combustion over lanthanum transition-metal perovskites: Role of oxygen mobility. Appl. Catal. A 2004, 262, 167-176. [CrossRef]

53. Kirchnerova, J.; Klvana, D.; Vaillancourt, J.; Chaouki, J. Evaluation of some cobalt and nickel based perovskites prepared by freeze-drying as combustion catalysts. Catal. Lett. 1993, 21, 77-87. [CrossRef]

54. Kirchenerov, J.; Klvana, D. Preparation and characterization of high surface perovskite electrocatalysts. Int. J. Hydrogen Energy 1994, 19, 501-506. [CrossRef]

55. Cimino, S.; Lisi, S.; De Rossi, S.; Faticanti, M.; Porta, P. Methane combustion and CO oxidation on $\mathrm{LaAl}_{1-\mathrm{x}} \mathrm{Mn}_{\mathrm{x}} \mathrm{O}_{3}$ perovskite-type oxide solid solutions. Appl. Catal. B 2003, 43, 397-406. [CrossRef]

56. Baiker, A.; Marti, P.E.; Keusch, P.; Fritsch, E.; Relier, A. Influence of the A-Site cation in $\mathrm{ACoO}_{3}(\mathrm{~A}=\mathrm{La}$, $\mathrm{Pr}, \mathrm{Nd}$, perovskite-type oxides on catalytic activity for methane combustion. J. Catal. 1994, 146, 268-276. [CrossRef]

57. Busca, G.; Daturi, M.; Finocchio, E.; Lorenzelli, V.; Ramis, G.; Willey, R.J. Transition metal mixed oxides as combustion catalysts: Preparation, characterization and activity mechanisms. Catal. Today 1997, 33, 239-249. [CrossRef]

58. Kirchnerova, J.; Alifanti, M.; Delmon, B. Evidence of phase cooperation in the $\mathrm{LaCoO}_{3}-\mathrm{CeO}_{2}-\mathrm{Co}_{3} \mathrm{O}_{4}$ catalytic system in relation to activity in methane combustion. Appl. Catal. A 2002, 231,65-80. [CrossRef]

59. Yi, N.; Cao, Y.; Su, Y.; Dai, W.L.; He, H.Y.; Fan, K.N. Nanocrystalline $\mathrm{LaCoO}_{3}$ perovskite particles confined in SBA-15 silica as a new efficient catalyst for hydrocarbon oxidation. J. Catal. 2005, 230, 249-253. [CrossRef]

60. Yamazoe, N.; Teraoka, Y. Oxidation catalysis of perovskites-Relationships to bulk structure and composition (valency, defect, etc.). Catal. Today 1990, 8, 175-199. [CrossRef]

61. Rossetti, I.; Biffi, C.; Forni, L. Oxygen non-stoichiometry in perovskitic catalysts: Impact on activity for the flameless combustion of methane. Chem. Eng. J. 2010, 162, 768-775. [CrossRef]

62. Koirala, R.; Pratsinis, S.E.; Baiker, A. Synthesis of catalytic materials in flames: Opportunities and challenges. Chem. Soc. Rev. 2016, 45, 3053-3068. [CrossRef]

63. Milt, V.G.; Spretz, R.; Ulla, M.A.; Lambardo, E.A. The nature of active sites for the oxidation of methane on La-based perovskites. Catal. Lett. 1996, 42, 57-63. [CrossRef]

64. Wei, X.; Hug, P.; Figi, R.; Trottmann, M.; Weidenkaff, A.; Ferri, D. Catalytic combustion of methane on nano-structured perovskite-type oxides fabricated by ultrasonic spray combustion. Appl. Catal. B 2010, 94, 27-37. [CrossRef]

65. Rossetti, I.; Forni, L. Catalytic flameless combustion of methane over perovskites prepared by flame-hydrolysis. Appl. Catal. B 2001, 33, 345-352. [CrossRef]

66. Ding, Y.; Wang, S.; Zhang, L.; Chen, Z.; Wang, M.; Wang, S. A facile method to promote $\mathrm{LaMnO}_{3}$ perovskite catalyst for combustion of methane. Catal. Commun. 2017, 97, 88-92. [CrossRef]

67. Lu, Y.; Eyssler, A.; Otal, E.H.; Matam, S.K.; Brunko, O.; Weidenkaff, A.; Ferri, D. Influence of the synthesis method on the structure of Pd-substituted perovskite catalysts for methane oxidation. Catal. Today 2013, 208, 42-47. [CrossRef]

68. Lee, N.H.; Kim, J.H.; Oh, H.J.; Kim, S.J. In-Situ preparation of highly crystallized ZnO manopowders by ultrasonic spraying combustion method. Solid State Phenom. 2007, 121-123, 1269-1272. [CrossRef]

69. Marti, P.E.; Baiker, A. Influence of the A-site cation in $\mathrm{AMnO}_{3+\mathrm{x}}$ and $\mathrm{AFeO}_{3+\mathrm{x}}(\mathrm{A}=\mathrm{La}, \mathrm{Pr}, \mathrm{Nd}$ and Gd) perovskite-type oxides on the catalytic activity for methane combustion. Catal. Lett. 1994, 26, 71-84. [CrossRef] 
70. Cimino, S.; Lisi, L.; Pirone, R.; Russo, G.; Turco, M. Methane combustion on perovskites-based structured catalysts. Catal. Today 2000, 59, 19-31. [CrossRef]

71. Marchetti, L.; Forni, L. Catalytic combustion of methane over perovskites. Appl. Catal. B 1998, 15, 179-187. [CrossRef]

72. Ciambelli, P.; Cimino, S.; De Rossi, S.; Faticanti, M.; Lisi, L.; Minelli, G.; Pettiti, I.; Porta, P.; Russo, G.; Turco, M. $\mathrm{AMnO}_{3}(\mathrm{~A}=\mathrm{La}, \mathrm{Nd}, \mathrm{Sm})$ and $\mathrm{Sm}_{1-\mathrm{x}} \mathrm{Sr}_{\mathrm{x}} \mathrm{MnO}_{3}$ perovskites as combustion catalysts: Structural, redox and catalytic properties. Appl. Catal. B 2000, 24, 243-253. [CrossRef]

73. Marti, P.E.; Maciejewski, M.; Baiker, A. Methane combustion over $\mathrm{La}_{0.8} \mathrm{Sr}_{0.2} \mathrm{MnO}_{3+\mathrm{x}}$ supported on $\mathrm{MAl}_{2} \mathrm{O}_{4}$ ( $\mathrm{M}=\mathrm{Mg}$, Ni and Co) spinels. Appl. Catal. B 1994, 4, 225-235. [CrossRef]

74. Wang, Y.; Arandiyan, H.; Tahini, H.A.; Scott, J.; Tan, X.; Dai, H.; Gale, J.D.; Rohl, A.L.; Smith, S.C.; Amal, R. The controlled disassembly of mesostructured perovskites as an avenue to fabricating high performance nanohybrid catalysts. Nat. Commun. 2017, 8, 15553. [CrossRef]

75. Daturi, M.; Busca, G.; Groppi, G.; Forzatti, P. Preparation and characterisation of $\mathrm{SrTi}_{1-\mathrm{x}-\mathrm{y}} \mathrm{Zr}_{\mathrm{x}} \mathrm{Mn}_{\mathrm{y}} \mathrm{O}_{3}$ solid solution powders in relation to their use in combustion catalysis. Appl. Catal. B 1997, 12, 325-337. [CrossRef]

76. Pecchi, G.; Reyes, P.; Zamora, R.; Campos, C.; Cadus, L.E.; Barbero, B.P. Effect of the preparation method on the catalytic activity of $\mathrm{La}_{1-x} \mathrm{Ca}_{x} \mathrm{FeO}_{3}$ perovskite-type oxides. Catal. Today 2008, 133-135, 420-427. [CrossRef]

77. Ciambelli, P.; Cimino, S.; De Rossi, S.; Lisi, L.; Minelli, G.; Porta, P.; Russo, G. $\mathrm{AFeO}_{3}(\mathrm{~A}=\mathrm{La}, \mathrm{Nd}, \mathrm{Sm})$ and $\mathrm{LaFe}_{1-\mathrm{x}} \mathrm{Mg}_{\mathrm{x}} \mathrm{O}_{3}$ perovskites as methane combustion and $\mathrm{CO}$ oxidation catalysts: Structural, redox and catalytic properties. Appl. Catal. B 2001, 29, 239-250. [CrossRef]

78. Ciambelli, P.; Cimino, S.; Lisi, L.; Faticanti, M.; Minelli, G.; Pettiti, I.; Porta, P. La, Ca and Fe oxide perovskites: Preparation, characterization and catalytic properties for methane combustion. Appl. Catal. B 2001, 33, 193-203. [CrossRef]

79. Pecchi, G.; Jiliberto, M.G.; Buljan, A.; Delgado, E.J. Relation between defects and catalytic activity of calcium doped $\mathrm{LaFeO}_{3}$ perovskite. Solid State Ion. 2011, 187, 27-32. [CrossRef]

80. Kucharczyk, B.; Tylus, W. Partial substitution of lanthanum with silver in the $\mathrm{LaMnO}_{3}$ perovskite: Effect of the modification on the activity of monolithic catalysts in the reactions of methane and carbon oxide oxidation. Appl. Catal. A 2008, 335, 28-36. [CrossRef]

81. Kucharczyk, B.; Okal, J.; Tylus, W.; Winiarski, J.; Szczygiel, B. The effect of the calcination temperature of $\mathrm{LaFeO}_{3}$ precursors on the properties and catalytic activity of perovskite in methane oxidation. Ceram. Int. 2019, 45, 2779-2788. [CrossRef]

82. Specchia, S.; Toniato, G. Natural gas combustion catalysts for environmental-friendly domestic burners. Catal. Today 2009, 147, 99-106. [CrossRef]

83. Klvanaa, D.; Kirchnerova, J.; Chaouki, J.; Delval, J.; Yaici, W. Fiber-supported perovskites for catalytic combustion of natural gas. Catal. Today 1999, 47, 115-121. [CrossRef]

84. Pattini, F. Growth of Oxide Thin Films for Energy Devices by Pulsed Electron Deposition. Ph.D. Thesis, Università degli Studi di Parma, Parma, Italy, 2009. Available online: https://www.repository.unipr.it/handle/ 1889/1001 (accessed on 8 November 2020).

85. Norton, D.P. Pulsed Laser Deposition of Complex Materials: Progress Toward Applications. In Pulsed Laser Deposition of Thin films; Eason, R., Ed.; Wiley: Hoboken, NJ, USA, 2007; pp. 3-28.

86. Constantinescu, C.; Dinescu, M. Thin films development by pulsed laser-assisted deposition. Physics AUC 2010, 20, 43-56.

87. Marozau, I.; Shkabko, A.; Dinescu, G.; Döbeli, M.; Lippert, T.; Logvinovich, D.; Malllepell, M.; Weidenkaff, A.; Wokaun, A. RF-plasma assisted pulsed laser deposition of nitrogen-doped $\mathrm{SrTiO}_{3}$ thin films. Appl. Phys. A 2008, 93, 721-727. [CrossRef]

88. Beckers, L.; Schubert, J.; Zander, W.; Ziesmann, J.; Eckau, A.; Leinenbach, P.; Buchal, C. Structural and optical characterization of epitaxial wave guiding $\mathrm{BaTiO}_{3}$ thin films on MgO. J. Appl. Phys. 1998, 83, 3305-3310. [CrossRef]

89. Mi, S.B.; Jia, C.L.; Heeg, T.; Trithaveesak, O.; Schubert, J.; Urban, K. Heterostructures of $\mathrm{BaTiO}_{3}$ bilayer films grown on $\mathrm{SrTiO}_{3}$ (001) under different oxygen pressures. J. Cryst. Growth 2005, 283, 425-430. [CrossRef]

90. Berini, B.; Evain, M.; Fouchet, A.; Dumont, Y.; Popova, E.; Keller, N. In situ optical characterization of metal-insulator transition in $\mathrm{LaNiO}_{3}$ and $\mathrm{SrTiO}_{3}$ perovskites in pulsed laser deposition chamber. Phase Transit. 2011, 84, 501-508. [CrossRef] 
91. Cillessen, J.F.M.; Wolf, R.M.; Giesbers, J.B.; Blom, P.W.M.; Grosse-Holz, K.O.; Pastoor, E. Growth, structuring and characterisation of all-oxide thin film devices prepared by pulsed laser deposition. Appl. Surf. Sci. 1996, 96-98, 744-751. [CrossRef]

92. Francis, A.; Salvador, P. Synthesis, structures, and physical properties of yttrium-doped strontium manganese oxide films. Mat. Res. Soc. Symp. Proc. 2002, 718, D9.4.1-D9.4.6. [CrossRef]

93. Hawley, M.E.; Adams, C.D.; Arendt, P.N.; Brosha, E.L.; Garzon, F.H.; Houlton, R.J.; Hundley, M.F.; Heffner, R.H.; Jia, Q.X.; Neumeier, J.; et al. CMR films structure as a function of growth and processing. J. Cryst. Growth 1997, 174, 455-463. [CrossRef]

94. Surthi, S.; Kotru, S.; Pandey, R.K. Characterization of integrated heterostructures of SbSI-La ${ }_{0.67} \mathrm{Ca}_{0.33} \mathrm{MnO}_{3}$. Mater. Lett. 2003, 57, 3455-3460. [CrossRef]

95. Chang, J.; Lee, J.W.; Kim, S.K. Layer-by-layer growth of $\mathrm{SrFeO}_{3-\delta}$ thin films on atomically flat single-terminated $\mathrm{SrRuO}_{3} / \mathrm{SrTiO}_{3}$ (111) surfaces. J. Cryst. Growth 2010, 312, 621-623. [CrossRef]

96. Sahner, K.; Moos, R.; Matam, M.; Tunney, J.J.; Post, M. Hydrocarbon sensing with thick and thin film p-type conducting perovskite materials. Sens. Actuators B Chem. 2005, 108, 102-112. [CrossRef]

97. Pignolet, A.; Satyalakshmi, K.M.; Alexe, M.; Zakharov, N.D.; Harnagea, C.; Senz, S.; Hesse, D.; Gösele, U. Epitaxial bismuth-layer-structured perovskite ferroelectric thin films grown by pulsed laser deposition. Integr. Ferroelectr. 1999, 26, 21-29. [CrossRef]

98. Coy, L.E.; Rebled, J.; Ventura, J.; Yate, L.; Ferrater, C.; Langenberg, E.; Polo, M.C.; Xuriguera, E.; Peiro, F.; Varela, M. Crystalline domains in epitaxial $\mathrm{Y}\left(\mathrm{Ni}_{0.5} \mathrm{Mn}_{0.5}\right) \mathrm{O}_{3}$ thin films grown by PLD on different STO substrates. Appl. Surf. Sci. 2015, 324, 114-122. [CrossRef]

99. Hassini, A.; Gervais, M.; Coulon, J.; Phuoc, V.T.; Gervais, F. Synthesis of $\mathrm{Ca}_{0.25} \mathrm{Cu}_{0.75} \mathrm{TiO}_{3}$ and infrared characterization of role played by copper. Mater. Sci. Eng. B 2001, 87, 164-168. [CrossRef]

100. Khan, M.A.; Comyn, T.P.; Bell, A.J. Deposition of $\mathrm{PbTiO}_{3}$ films on Pt/Si substrates using pulsed laser deposition. J. Eur. Ceram. Soc. 2008, 28, 591-597. [CrossRef]

101. Wang, Z.J.; Kokawa, H.; Maeda, R. Growth of lead zirconate titanate thin films by hybrid processing: Sol-gel method and pulsed-laser deposition. J. Cryst. Growth 2004, 262, 359-365. [CrossRef]

102. Yun, K.Y.; Ricinschi, D.; Kanashima, T.; Noda, M.; Okuyama, M. Giant ferroelectric polarization beyond $150 \mathrm{C} / \mathrm{cm}^{2}$ in $\mathrm{BiFeO}_{3}$ thin film. Jpn. J. Appl. Phys. 2004, 43, 647-648. [CrossRef]

103. Béa, H.; Bibes, M.; Barthélémy, A.; Bouzehouane, K.; Jacquet, E.; Khodan, A.; Contour, J.P.; Fusil, S.; Wyczisk, F.; Forget, A.; et al. Influence of parasitic phases on the properties of $\mathrm{BiFeO}_{3}$ epitaxial thin films. Appl. Phys. Lett. 2005, 87, 072508. [CrossRef]

104. Zhang, G.; Cheng, J.; Chen, R.; Yu, S.; Meng, Z. Preparation of $\mathrm{BiFeO}_{3}$ thin films by pulsed laser deposition method. Trans. Nonferrous. Met. Soc. China 2006, 16, 123-125. [CrossRef]

105. Harnagea, C.; Cojocaru, C.V.; Gautreau, O.; Nechache, R.; Normandin, F.; Veres, T.; Pignolet, A. Piezoresponse force microscopy of PLD-grown multiferroic $\mathrm{BiFeO}_{3}$ films and mesostructures. Integr. Ferroelectr. 2006, 83, 1-12. [CrossRef]

106. Go, H.; Wakiya, N.; Funakubo, H.; Satoh, K.; Kondo, M.; Cross, J.S.; Maruyama, K.; Mizutani, N.; Shinozaki, K. Effect of oxygen annealing on ferroelectricity of $\mathrm{BiFeO}_{3}$ thin films formed by Pulsed Laser Deposition. Jpn. J. Appl. Phys. 2007, 46, 3491-3494. [CrossRef]

107. Himcinschi, C.; Vrejoiu, I.; Friedrich, M.; Ding, L.; Cobet, C.; Esser, N.; Alexe, M.; Zahn, D.R.T. Optical characterisation of $\mathrm{BiFeO}_{3}$ epitaxial thin films grown by pulsed-laser deposition. Phys. Status Solidi C 2010, 7, 296-299. [CrossRef]

108. Vrejoiu, I.; Alexe, M.; Hesse, D.; Gösele, U. Functional perovskites-From epitaxial films to nanostructured arrays. Adv. Funct. Mater. 2008, 18, 3892-3906. [CrossRef]

109. Ravalia, A.; Vagadia, M.; Trivedi, P.; Solanki, P.S.; Asokan, K.; Ojha, S.; Thakur, O.P.; Choudhary, R.J.; Phase, D.M.; Kuberkar, D.G. Role of oxygen in multiferroic behavior of $\mathrm{BiFeO}_{3}$ films grown on $0.2 \% \mathrm{Nb}$ doped $\mathrm{SrTiO}_{3}$. Solid State Commun. 2013, 169, 10-13. [CrossRef]

110. Prashanthi, K.; Gupta, M.; Tsui, Y.Y.; Thundat, T. Effect of annealing atmosphere on microstructural and photoluminescence characteristics of multiferroic $\mathrm{BiFeO}_{3}$ thin films prepared by pulsed laser deposition technique. Appl. Phys. A 2012, 110, 903-907. [CrossRef]

111. Zhao, L.; Lu, Z.; Zhang, F.; Tian, G.; Song, X.; Li, Z.; Huang, K.; Zhang, Z.; Qin, M.; Wu, S.; et al. Current rectifying and resistive switching in high density $\mathrm{BiFeO}_{3}$ nanocapacitor arrays on $\mathrm{Nb}-\mathrm{SrTiO}_{3}$ substrates. Sci. Rep. 2015, 5, 9680. [CrossRef] 
112. Jiang, Z.Z.; Guan, Z.; Yang, N.; Xiang, P.H.; Qi, R.J.; Huang, R.; Yang, P.X.; Zhong, N.; Duan, C.G. Epitaxial growth of $\mathrm{BiFeO}_{3}$ films on $\mathrm{SrRuO}_{3} / \mathrm{SrTiO}_{3}$. Mater. Charact. 2017, 131, 217-223. [CrossRef]

113. Ravaliya, K.; Ravalia, A.; Pandya, D.D.; Solanki, P.S.; Shah, N.A. Strain and morphology control over electrical behavior of pulsed laser deposited $\mathrm{BiFeO}_{3}$ films. Thin Solid Films 2018, 645, 436-443. [CrossRef]

114. Singh, G.; Yadav, R.P.; Bhasker, H.P.; Kumar, M.; Rajput, P.; Rao, P.N.; Rai, S.K.; Singh, M.K. Investigation of fractal feature of multiferroic $\mathrm{BiFeO}_{3}$ thin films deposited on different substrates. Mater. Res. Express 2018, 5, 126405. [CrossRef]

115. Lee, D.; Kim, M.G.; Ryu, S.; Jang, H.M.; Lee, S.G. Epitaxially grown La-modified $\mathrm{BiFeO}_{3}$ magnetoferroelectric thin films. Appl. Phys. Lett. 2005, 86, 222903. [CrossRef]

116. Sahoo, K.K.; Katoch, R.; Brajesh, K.; Garg, A.; Gupta, R. Improved ferroelectric response of pulsed laser deposited $\mathrm{BiFeO}_{3}-\mathrm{PbTiO}_{3}$ thin films around morphotropic phase boundary with interfacial $\mathrm{PbTiO}_{3}$ buffer layer. J. Appl. Phys. 2020, 127, 064101. [CrossRef]

117. Khan, M.A.; Comyn, T.P.; Bell, A.J. Growth and characterization of tetragonal bismuth ferrite-lead titanate thin films. Acta Mater. 2008, 56, 2110-2118. [CrossRef]

118. Talley, K.R.; Barron, S.C.; Nguyen, N.; Wong-Ng, W.; Martin, J.; Zhang, Y.L.; Song, X. Thermoelectric properties of the $\mathrm{LaCoO}_{3}-\mathrm{LaCrO}_{3}$ system using a high-throughput combinatorial approach. Solid State Sci. 2017, 64, 7-12. [CrossRef]

119. Choi, W.S.; Marton, Z.; Jang, S.Y.; Moon, S.J.; Jeon, B.C.; Shin, J.H.; Seo, S.S.A.; Noh, T.W.; Myung-Whun, K.; Lee, H.N.; et al. Effects of oxygen-reducing atmosphere annealing on $\mathrm{LaMnO}_{3}$ epitaxial thin films. J. Phys. D Appl. Phys. 2009, 42, 165401. [CrossRef]

120. Zhang, X.; Zhang, A.M.; Xie, W.M.; Lin, J.G.; Wu, X.S. Effect of strain-modulated lattice distortion on the magnetic properties of $\mathrm{LaMnO}_{3}$ films. Physica B Condens. Matter. 2015, 476, 114-117. [CrossRef]

121. Debnath, J.C.; Strydom, A.M. Large low field magneto-resistance and temperature coefficient of resistance in $\mathrm{La}_{0.8} \mathrm{Ca}_{0.2} \mathrm{MnO}_{3}$ epitaxial thin film. J. Alloys Compd. 2015, 621, 7-11. [CrossRef]

122. Xiong, H.F.; Cheng, T.D.; Tang, X.G.; Chen, J.; Liu, Q.X. X-ray photoelectron spectroscopy of $\left(\mathrm{La}_{0.7} \mathrm{Sr}_{0.3}\right) \mathrm{MnO}_{3}$ thin films prepared by Pulsed Laser Deposition. Adv. Mat. Res. 2011, 284-286, 2191-2197. [CrossRef]

123. Brown, G.W.; Jia, Q.X.; Peterson, E.J.; Hristova, D.K.; Hundley, M.F.; Thompson, J.D.; Maggiore, C.J.; Tesmer, J.; Hawley, M.E. Growth and magnetic structure of $\mathrm{La}_{0.67} \mathrm{Sr}_{0.33} \mathrm{MnO}_{3}$ films. Mat. Res. Soc. Symp. Proc. 1997, 474, 179-184. [CrossRef]

124. Iwata, N.; Huijben, M.; Rijnders, G.; Yamamoto, H.; Blank, D.H.A. Growth of $\mathrm{CaFeO} / \mathrm{LaFeO}_{3}$ Superlattice on $\mathrm{SrTiO}_{3}(100)$ Substrates. Mat. Res. Soc. Symp. Proc. 2011, 1292, 125-130. [CrossRef]

125. Park, J.; Kim, Y.; Lee, D.; Song, J.H.; Park, J.H. Twin-free epitaxial $\mathrm{LaFeO}_{3}$ films grown on orthorhombic $\mathrm{GdScO}_{3}(110)$ substrates. J. Korean Phys. Soc. 2020, 76, 273-276. [CrossRef]

126. Tsuchiya, Y.; Norota, K.; Watabe, Y.; Kuroda, T.; Iwata, N.; Hashimoto, T.; Yamamoto, H. Growth difference of $\mathrm{LaFeO}_{3}$ thin films by pulsed laser deposition method using the targets prepared by pechini and conventional solid solution methods. Trans. Mat. Res. Soc. Jap. 2012, 37, 369-372. [CrossRef]

127. Liu, H.; Zhu, J.; Xiao, D. Preparation and characterization of $\mathrm{LaFeO}_{3}$ thin films on (100) $\mathrm{SrTiO}_{3}$ substrates by pulsed laser deposition. J. Adv. Dielectr. 2011, 1, 363-367. [CrossRef]

128. Andrei, F.; Boerasu, I.; Moldovan, A.; Dinescu, M.; Ion, V.; Mihailescu, C.; Scarisoreanu, N.D.; Leca, V. The effects of the oxygen content on the photoelectrochemical properties of $\mathrm{LaFeO}_{3}$ perovskite thin films obtained by pulsed laser deposition. Appl. Phys. A 2019, 125, 807. [CrossRef]

129. Manzoor, S.; Somvanshi, A.; Husain, S. Structural analysis of $\mathrm{LaFeO}_{3}$ thin films grown on $\mathrm{SrTiO}_{3}$ and $\mathrm{LaAlO}_{3}$ substrates. AIP Conf. Proc. 2018, 1942, 80011. [CrossRef]

130. Cieniek, Ł.; Kopia, A.; Kusiński, J.; Kowalski, K.; Moskalewicz, T.; Cyza, A.; Maziarz, W. Microstructure and selected mechanical and electrical property analysis of Sr-doped $\mathrm{LaCoO}_{3}$ perovskite thin films deposited by the PLD technique. Int. J. Mater. Res. 2018, 110, 32-41. [CrossRef]

131. Kopia, A.; Cieniek, Ł.; Kowalski, K.; Kusiński, J. Influence of Sr-Doping on the structure of $\mathrm{LaCoO}_{3}$ thin films prepared by pulsed laser deposition. Solid State Phenom. 2015, 231, 19-24. [CrossRef]

132. Cyza, A.; Cieniek, Ł.; Kopia, A. Perovskite $\mathrm{La}_{1-x} \mathrm{Sr}_{x} \mathrm{FeO}_{3}$ thin films deposited by laser ablation process. Arch. Metall. Mater. 2016, 61, 1063-1067. [CrossRef]

133. Dash, U.; Acharya, S.K.; Cho, S.W.; Lee, S.; Lee, K.; Chae, S.C.; Cho, M.R.; Jung, C.U. Large magnetoresistance in $\mathrm{LaFeO}_{3}$ substituted $\mathrm{SrRuO}_{3}$ epitaxial thin films. J. Alloys Compd. 2017, 724, 549-554. [CrossRef] 
134. Kolte, J.; Daryapurkar, A.S.; Agarwal, M.; Gulwade, D.D.; Gopalan, P. Effect of substrate temperature on the structural and electrical properties of $\mathrm{La}$ and $\mathrm{Mn}$ co-doped $\mathrm{BiFeO}_{3}$ thin films. Thin Solid Films 2016, 619, 308-316. [CrossRef]

135. Izumi, H.; Yoshimura, T.; Fujimura, N. Growth and ferroelectric properties of La and $\mathrm{Al}$ codoped $\mathrm{BiFeO}_{3}$ epitaxial films. J. Appl. Phys. 2017, 121, 174102. [CrossRef]

136. Zhao, Y.; Srivastava, R.; Fournier, P.; Smolyaninova, V.; Rajeswari, M.; Wu, T.; Li, Z.Y.; Greene, R.L.; Venkatesan, T. Transport and magnetic properties of $\mathrm{La}_{0.8} \mathrm{Ce}_{0.2} \mathrm{MnO}_{3}$ thin films grown by pulsed laser deposition. J. Magn. Magn. Mater. 2000, 220, 161-166. [CrossRef]

137. Lin, T.K.; Chang, H.W.; Chen, B.A.; Wei, D.H.; Wang, C.R.; Tu, C.S. Effect of Pr substitution on the structure, nanomechanical and multiferroic characterizations of $\mathrm{Bi}_{1-x} \mathrm{Pr}_{x} \mathrm{FeO}_{3}$ polycrystalline films. Surf. Coat. Technol. 2020, 393, 125728. [CrossRef]

138. Bowman, R.M.; Catalan, G.; Corbett, M.H.; O’Neill, D.; Gregg, J.M. PLD of metal insulator and relaxor electroceramic thin films. In 11th International School on Quantum Electronics: Laser Physics and Applications, Proceedings of the SPIE 2001; Atanasov, P.A., Cartaleva, C., Eds.; SPIE: Bellingham, WA, USA, 2001; Volume 4397, pp. 273-284. [CrossRef]

139. Shiyani, T.; Shekhada, K.G.; Savaliya, C.R.; Markna, J.H. Tuning the metal-insulator transition in $\mathrm{NdNiO}_{3}$ thin films. AIP Conf. Proc. 2017, 1837, 040006. [CrossRef]

140. Puli, V.S.; Pradhan, D.K.; Katiyar, R.K.; Coondoo, I.; Panwar, N.; Misra, P.; Chrisey, D.B.; Scott, J.F.; Katiyar, R.S. Photovoltaic effect in transition metal modified polycrystalline $\mathrm{BiFeO}_{3}$ thin films. J. Phys. D Appl. Phys. 2014, 47, 075502. [CrossRef]

141. Lin, T.K.; Shen, C.Y.; Kao, C.C.; Chang, C.F.; Chang, H.W.; Wang, C.R.; Tu, C.S. Structural evolution, ferroelectric, and nanomechanical properties of $\mathrm{Bi}_{1-\mathrm{x}} \mathrm{Sm}_{\mathrm{x}} \mathrm{FeO}_{3}$ films $(\mathrm{x}=0.05-0.16)$ on glass substrates. J. Alloys Compd. 2019, 787, 397-406. [CrossRef]

142. Yu, Y.; Zhang, X.; Yang, J.J.; Wang, J.W.; Zhao, Y.G. Microstructure and strain relaxation of orthorhombic $\mathrm{TmMnO}_{3}$ epitaxial thin films. J. Cryst. Growth 2012, 338, 280-282. [CrossRef]

143. Caricato, A.P.; Luches, A. Applications of the matrix-assisted pulsed laser evaporation method for the deposition of organic, biological and nanoparticle thin films: A review. Appl. Phys. A 2011, 105, 565-582. [CrossRef]

144. Papavlu, A.P.; Dinca, V.; Filipescu, M.; Dinescu, M. Matrix-assisted pulsed laser evaporation of organic thin gilms: Applications in biology and chemical sensors. In Laser Ablation—From Fundamentals to Applications; Itina, T.E., Ed.; InTech: Rijeka, Croatia, 2017; pp. 171-189. [CrossRef]

145. Chirisey, D.B.; Pique, A.; McGill, R.A.; Horwitz, J.S.; Ringeisen, B.R.; Bubb, D.M.; Wu, P.K. Laser deposition of polymer and biomaterial films. Chem. Rev. 2003, 103, 553-576. [CrossRef]

146. Pique, A.; McGill, R.A.; Chrisey, D.B.; Leonhardt, D.; Mslna, T.E.; Spargo, B.J.; Callahan, J.H.; Vachet, R.W.; Chung, R.; Bucaro, M.A. Growth of organic thin films by the matrix assisted pulsed laser evaporation (MAPLE) technique. Thin Solid Films 1999, 355/356, 536-541. [CrossRef]

147. Lippert, T.; Chrisey, D.B.; Purice, A.; Constantinescu, C.; Filipescu, M.; Scarisoreanu, N.D.; Dinescu, M. Laser processing of soft materials. Rom. Rep. Phys. 2007, 59, 483-498.

148. Queraltó, A.; György, E.; Ivan, R.; Pérez del Pino, Á.; Frohnhoven, R.; Mathur, S. Enhanced UV-Vis photodegradation of nanocomposite reduced graphene oxide/ferrite nanofiber films prepared by laser-assisted evaporation. Crystals 2020, 10, 271. [CrossRef]

149. Barraza, E.T.; Dunlap-Shohl, W.A.; Mitzi, D.B.; Stiff-Roberts, A.D. Deposition of methylammonium lead triiodide by resonant infrared matrix-assisted pulsed laser evaporation. J. Electron. Mater. 2017, 47, 917-926. [CrossRef]

150. Dunlap-Shohl, W.A.; Barraza, E.T.; Barrette, A.; Gundogdu, K.; Stiff-Roberts, A.D.; Mitzi, D.B. MAPbI 3 solar cells with absorber deposited by resonant infrared matrix-assisted pulsed laser evaporation. ACS Energy Lett. 2018, 3, 270-275. [CrossRef]

151. Manoharan, Y.; Hosseini, S.E.; Butler, B.; Alzhahrani, H.; Senior, B.T.F.; Ashuri, T.; Krohn, J. Hydrogen fuel cell vehicles; Current status and future prospect. Appl. Sci. 2019, 9, 2296. [CrossRef]

152. Fan, Z.; Sunc, K.; Wang, J. Perovskites for photovoltaics: A combined review of organic-inorganic halide perovskites and ferroelectric oxide perovskites. J. Mater. Chem. A 2015, 3, 18809-18828. [CrossRef]

153. Lede, J.; Lapicque, F.; Villermaux, J. Production of hydrogen by direct thermal decomposition of water. Int. J. Hydrogen Energy 1983, 8, 675-679. [CrossRef] 
154. Luciani, G.; Landi, G.; Aronnea, A.; Di Benedetto, A. Partial substitution of B cation in La0.6Sr0.4MnO3 perovskites: A promising strategy to improve the redox properties useful for solar thermochemical water and carbon dioxide splitting. Solar Energy 2018, 171, 1-7. [CrossRef]

155. Bhosale, R.R. Solar hydrogen production via thermochemical magnesium oxide-Magnesium sulfate water splitting cycle. Fuel 2020, 275, 117892. [CrossRef]

156. Bhandari, R.; Trudewind, A.C.; Zapp, P. Life cycle assessment of hydrogen production via electrolysis-A review. J. Clean. Prod. 2014, 85, 151-163. [CrossRef]

157. Hisatomi, T.; Domen, K. Reaction systems for solar hydrogen production via water splitting with particulate semiconductor photocatalysts. Nat. Catal. 2019, 2, 387-399. [CrossRef]

158. Samsudin, F.R.M.; Bashiri, R.; Mohamed, M.M.; Ng, H.Y.; Sufian, S. Tailoring the morphological structure of $\mathrm{BiVO}_{4}$ photocatalyst for enhanced photoelectrochemical solar hydrogen production from natural lake water. Appl. Surf. Sci. 2020, 504, 144417. [CrossRef]

159. Mueller-Langer, F.; Tzimas, E.; Kaltschmitt, M.; Peteves, S. Techno-economic assessment of hydrogen production processes for the hydrogen economy for the short and medium term. Int. J. Hydrogen Energy 2007, 32, 3797-3810. [CrossRef]

160. Ramachandran, R.; Menon, R.K. An overview of industrial uses of hydrogen. Int. J. Hydrogen Energy 1998, 23, 593-598. [CrossRef]

161. Eliezer, D.; Eliaz, N.; Senkov, O.N.; Froes, F.H. Positive effects of hydrogen in metals. Mater. Sci. Eng. 2000, 280, 220-224. [CrossRef]

162. Edwards, P.P.; Kuznetsov, V.L.; David, W.I.F.; Brandon, N.P. Hydrogen and fuel cells: Towards a sustainable energy future. Energy Policy 2008, 36, 4356-4362. [CrossRef]

163. Abe, R. Recent progress on photocatalytic and photoelectrochemical water splitting under visible light irradiation. J. Photochem. Photobiol. C 2010, 11, 179-209. [CrossRef]

164. Hoffman, M.R.; Martin, S.T.; Choi, W. Environmental applications of semiconductor photocatalysis. Chem. Rev. 1995, 95, 69-96. [CrossRef]

165. Linsebigler, A.L.; Lu, G.Q.; Yates, J.T. Photocatalysis on $\mathrm{TiO}_{2}$ surfaces: Principles, mechanisms, and selected results. Chem. Rev. 1995, 95, 735-758. [CrossRef]

166. Serpone, N.; Sauve, G.; Koch, R.; Tahiri, H.; Pichat, P.; Piccinini, P.; Pelizzetti, E.; Hidaka, H. Standardization protocol of process efficiencies and activation parameters in heterogeneous photocatalysis: Relative photonic efficiencies לr. J. Photochem. Photobiol. 1996, 94, 191-203. [CrossRef]

167. Ismail, A.A.; Bahnemann, D.W. Photochemical splitting of water for hydrogen production by photocatalysis: A review. Sol. Energy Mater. Sol. Cells 2014, 28, 85-101. [CrossRef]

168. Wu, H.; Tan, H.L.; Toe, C.Y.; Scott, J.; Wang, L.; Amal, R.; Ng, H.Y. Photocatalytic and photoelectrochemical systems: Similarities and differences. Adv. Mater. 2019, 1-21. [CrossRef]

169. Benck, J.D.; Hellstern, T.R.; Kibsgaard, J.; Chakthranont, P.; Jaramillo, T.F. Catalyzing the hydrogen evolution reaction (HER) with molybdenum sulfide nanomaterials. ACS Catal. 2014, 4, 3957-3971. [CrossRef]

170. Kim, J.S.; Kim, B.; Kim, H.; Kang, K. Amorphous multinary phyllosilicate catalysts for electrochemical water oxidation. Adv. Energy Mater. 2018, 7, 18380-18387. [CrossRef]

171. Hu, C.; Zhang, L.; Gong, J. Recent progress made in the mechanism comprehension and design of electrocatalysts for alkaline water splitting. Energy Environ. Sci. 2019, 12, 2620-2645. [CrossRef]

172. Zheng, J.Y.; Jaroniek, M.; Qiao, S.Z. Design of electrocatalysts for oxygen- and hydrogen-involving energy conversion reactions. Chem. Soc. Rev. 2015, 44, 2060-2086. [CrossRef]

173. Seh, Z.W.; Kibsgaard, J.; Dickens, C.F.; Chorkendorff, I.; Nørskov, J.K.; Jaramillo, T.F. Combining theory and experiment in electrocatalysis: Insights into materials design. Science 2017, 355, 1-12. [CrossRef]

174. Yerga, N.R.M.; Alvarez-Galván, M.C.; Vaquero, F.; Arenales, J.; Fierro, J.L.G. Chapter 3-Hydrogen production from water splitting using photo-semiconductor catalysts. Ren. Hydrog. Technol. Prod. Purif. Storage Appl. Saf. 2013, 43-61. [CrossRef]

175. Li, J.; Wu, N. Semiconductor-based photocatalysts and photoelectrochemical cells for solar fuel generation: A review. Catal. Sci. Technol. 2015, 5, 1360-1384. [CrossRef]

176. Chen, Z.; Dinh, H.; Miller, E. Efficiency Definitions in the Field of PEC. In Photoelectrochemical Water Splitting: Standards, Experimental Methods, and Protocols; Springer: New York, NY, USA, 2013; pp. 7-16.

177. Murphy, A.; Barnes, P.; Randeniya, L.; Plumb, I.; Horne, M.; Glasscock, J. Efficiency of solar water splitting using semiconductor electrodes. Int. J. Hydrogen Energy 2006, 31, 1999-2017. [CrossRef] 
178. Smith, W.A. Photoelectrochemical Cell Design, Efficiency, Definitions, Standards, and Protocols. In Photoelectrochemical Solar Fuel Production; Giménez, S., Bisquert, J., Eds.; Springer: Cham, Switzerland, 2016; pp. 163-199. [CrossRef]

179. Fujishima, A.; Honda, K. Electrochemical photolysis of water at a semiconductor electrode. Nature 1972, 238, 37-38. [CrossRef]

180. Li, F.; Liu, Y.; Liu, R.; Sun, Z.; Zhao, D.; Kou, C. Preparation of Ca-doped $\mathrm{LaFeO}_{3}$ nanopowders in a reverse microemulsion and their visible light photocatalytic activity. Mater. Lett. 2010, 64, 223-225. [CrossRef]

181. Wang, G.; Wang, H.; Ling, Y.; Tang, Y.; Yang, X.; Fitzmorris, R.C.; Wang, C.; Zhang, J.Z.; Li, Y. Hydrogen-treated $\mathrm{TiO}_{2}$ nanowire arrays for photoelectrochemical water splitting. Nano Lett. 2011, 11, 3026-3033. [CrossRef] [PubMed]

182. Smith, I.C.; Hoke, E.T.; Solis-Ibarra, D.; McGehee, M.D.; Karunadasa, H.I. A layered hybrid perovskite solar-cell absorber with enhanced moisture stability. Angew. Chem. Int. Ed. 2014, 126, 11414-11417. [CrossRef]

183. Jiang, Q.; Rebollar, D.; Gong, J.; Piacentino, E.L.; Zheng, C.; Xu, T. Pseudohalide-induced moisture tolerance in perovskite $\mathrm{CH}_{3} \mathrm{NH}_{3} \mathrm{~Pb}(\mathrm{SCN})_{2} \mathrm{I}$ thin films. Angew. Chem. Int. Ed. 2015, 54, 11006. [CrossRef] [PubMed]

184. Da, P.; Cha, M.; Sun, L.; Wu, Y.; Wang, Z.S.; Zheng, G. High-performance perovskite photoanode enabled by Ni passivation and catalysis. Nano Lett. 2015, 15, 3452-3457. [CrossRef] [PubMed]

185. Hoang, M.T.; Pham, N.D.; Han, J.H.; Gardner, J.; Oh, I. Integrated photoelectrolysis of water implemented on organic metal halide perovskite photoelectrod. ACS Appl. Mater. Interfaces 2016, 19, 11904-11909. [CrossRef]

186. Wang, C.; Yang, C.; Wen, T.; Yang, H.G. Surface-functionalized perovskite films for stable photoelectrochemical water splitting. J. Mater. Chem. A 2017, 5, 910-913. [CrossRef]

187. Elseman, A.M.; Selim, M.S.; Luo, L.; Xu, C.Y.; Wang, G.; Jiang, Y.; Liu, D.B.; Liao, L.P.; Hao, Z.; Song, Q. Efficient and stable planar n-i-p perovskite solar cells with negligible hysteresis through solution-processed $\mathrm{Cu}_{2} \mathrm{O}$ nanocubes as a low-cost hole-transport material. ChemSusChem 2019, 18, 3808-3816. [CrossRef]

188. Upadhyay, S.; Shrivastava, J.; Solanki, A.; Choudhary, S.; Sharma, V.; Kumar, P.; Singh, N.; Satsangi, V.R.; Shrivastav, R.; Waghmare, U.V.; et al. Enhanced photoelectrochemical response of $\mathrm{BaTiO}_{3}$ with Fe doping: Experiments and first-principles analysis. J. Phys. Chem. C 2011, 115/49, 24373-24380. [CrossRef]

189. Jang, J.S.; Ahn, C.W.; Won, S.S.; Kim, J.H.; Choi, W.; Lee, B.S.; Yoon, J.H.; Kim, H.G.; Lee, J.S. Vertically aligned core-shell $\mathrm{PbTiO}_{3}-\mathrm{TiO}_{2}$ heterojunction nanotube array for photoelectrochemical and photocatalytic applications. J. Phys. Chem. C 2017, 121, 15063-15070. [CrossRef]

190. Wang, W.; Zhang, W.; Hao, C.; Wu, F.; Liang, Y.; Shi, H.; Wang, J.; Zhang, T.; Hua, Y. Enhanced photoelectrochemical activity and photocatalytic water oxidation of $\mathrm{NiO}$ nanoparticle-decorated $\mathrm{SrTiO}_{3}$ nanocube heterostructures: Interaction, interfacial charge transfer and enhanced mechanism. Sol. Energy Mater. Sol. Cells 2016, 152,1-9. [CrossRef]

191. Wang, F.; Liu, Y.; Ma, Z.; Li, H.; Kang, Z.; Shen, M. Enhanced photoelectrochemical response in $\mathrm{SrTiO}_{3}$ films decorated with carbon quantum dots. New J. Chem. 2013, 37, 290-294. [CrossRef]

192. Takata, T.; Domen, Z. Defect engineering of photocatalysts by doping of aliovalent metal cations for efficient water splitting. J. Phys. Chem. C 2009, 113/45, 19386-19388. [CrossRef]

193. Ikeda, S.; Hirao, K.; Ishino, S.; Matsumura, M.; Ohtani, B. Preparation of platinized strontium titanate covered with hollow silica and its activity for overall water splitting in a novel phase-boundary photocatalytic system. Catal. Today 2006, 117, 343-349. [CrossRef]

194. Kato, H.; Asakura, K.; Kudo, A. Highly efficient water splitting into $\mathrm{H}_{2}$ and $\mathrm{O}_{2}$ over lanthanum-doped $\mathrm{NaTaO}_{3}$ photocatalysts with high crystallinity and surface nanostructure. J. Am. Chem. Soc. 2003, 125, 3082-3089. [CrossRef] [PubMed]

195. Zhang, H.J.; Chen, G.; Li, Y.X.; Teng, Y.J. Electronic structure and photocatalytic properties of copper-doped $\mathrm{CaTiO}_{3}$. Int. J. Hydrogen Energy 2010, 35, 2713-2716. [CrossRef]

196. Li, J.J.; Jia, L.S.; Fang, W.P.; Zeng, J.L. Investigations on the effect of $\mathrm{Cu}^{2+} / \mathrm{Cu}^{1+}$ redox couples and oxygen vacancies on photocatalytic activity of treated $\mathrm{LaNi}_{1-\mathrm{x}} \mathrm{Cu}_{\mathrm{x}} \mathrm{O}_{3}(\mathrm{x}=0.1,0.4,0.5)$. Int. J. Hydrogen Energy 2010, 35, 5270-5275. [CrossRef]

197. Tang, P.; Chen, H.; Cao, F.; Pan, G. Magnetically recoverable and visible-light-driven nanocrystalline $\mathrm{YFeO}_{3}$ photocatalysts. Catal. Sci. Technol. 2011, 1, 1145-1148. [CrossRef]

198. Díez-García, M.I.; Celorrio, V.; Calvillo, L.; Tiwari, D.; Gómez, R.; Fermín, D.J. YFeO 3 photocathodes for hydrogen evolution. Electrochim. Acta 2017, 246, 365-371. [CrossRef] 
199. Alexe, M.; Hesse, D. Tip-enhanced photovoltaic effects in bismuth ferrite. Nat. Commun. 2011, 2, 256. [CrossRef]

200. Song, J.; Kim, T.L.; Lee, J.; Cho, S.Y.; Cha, J.; Jeon, S.Y.; An, H.; Kim, W.S.; Jung, Y.S.; Park, J.; et al. Domain-engineered $\mathrm{BiFeO}_{3}$ thin-film photoanodes for highly enhanced ferroelectric solar water splitting. Nano Res. 2018, 11, 642-655. [CrossRef]

201. Zhang, C.; Li, Y.; Chu, M.; Rong, N.; Xiao, P.; Zhang, Y. Hydrogen-treated $\mathrm{BiFeO}_{3}$ nanoparticles with enhanced photoelectrochemical performance. RSC Adv. 2016, 6, 24760-24767. [CrossRef]

202. Moniz, S.J.A.; Blackman, C.S.; Southern, P.; Weaver, P.M.; Tang, J.; Carmalt, C.J. Visible-light driven water splitting over $\mathrm{BiFeO}_{3}$ photoanodes grown via the LPCVD reaction of $\left[\mathrm{Bi}(\mathrm{OtBu})_{3}\right]$ and $\left[\mathrm{Fe}(\mathrm{OtBu})_{3}\right]_{2}$ and enhanced with a surface nickel oxygen evolution catalyst. Nanoscale 2015, 7, 16343-16353. [CrossRef] [PubMed]

203. Gao, F.; Yuan, Y.; Wang, K.; Chen, X.; Chen, F.; Liu, J.; Ren, Z. Preparation and photoabsorption characterization of $\mathrm{BiFeO}_{3}$ nanowires. Appl. Phys. Lett. 2006, 89, 102506-102900. [CrossRef]

204. Joshi, U.A.; Jang, J.S.; Borse, P.H.; Lee, J.S. Microwave synthesis of singlecrystalline perovskite $\mathrm{BiFeO}_{3}$ nanocubes for photoelectrode and photocatalytic applications. Appl. Phys. Lett. 2008, 92, 242106. [CrossRef]

205. Chen, X.Y.; Yu, T.; Gao, F.; Zhang, H.T.; Liu, L.F.; Wang, Y.M.; Li, Z.S.; Zou, Z.G. Application of weak ferromagnetic $\mathrm{BiFeO}_{3}$ films as the photoelectrode material under visible-light irradiation. Appl. Phys. Lett. 2007, 91, 022114. [CrossRef]

206. Cao, D.W.; Wang, Z.J.; Wen, L.Y.; Mi, Y.; Lei, Y. Switchable charge-transfer in the photoelectrochemical energy-conversion process of ferroelectric $\mathrm{BiFeO}_{3}$ photoelectrodes. Angew. Chem. Int. Ed. 2014, 53, 1-6. [CrossRef]

207. Cho, S.; Wang, J.W.; Zhang, W.R.; Suwardi, A.; Wang, H.W.; Wang, D.W.; MacManus-Driscoll, J.L. Single-crystalline thin films for studying intrinsic properties of $\mathrm{BiFeO}_{3}-\mathrm{SrTiO}_{3}$ solid solution photoelectrodes in solar energy conversion. Chem. Mater. 2015, 27, 6635-6641. [CrossRef]

208. Rong, N.; Chu, M.; Tang, Y.; Zhang, C.; Cui, Z.; He, H.; Zhang, Y.; Xiao, P. Improved photoelectrocatalytic properties of Ti-doped $\mathrm{BiFeO}_{3}$ films for water oxidation. J. Mater. Sci. 2016, 51, 5712-5723. [CrossRef]

209. Haydous, F.; Scarisoreanu, N.D.; Birjega, R.; Ion, V.; Lippert, T.; Dumitrescu, N.; Moldovan, A.; Andrei, A.; Teodorescu, S.V.; Ghica, C.; et al. Rolling dopant and strain in Y-doped BiFeO 3 epitaxial thin films for photoelectrochemical water splitting. Sci. Rep. 2018, 8, 15826. [CrossRef]

210. Zhang, T.; Shen, Y.; Qiu, Y.; Liu, Y.; Xiong, R.; Shi, J.; Wei, J. Facial synthesis and photoreaction mechanism of $\mathrm{BiFeO}_{3} / \mathrm{Bi}_{2} \mathrm{Fe}_{4} \mathrm{O}_{9}$ heterojunction nanofibers. ACS Sustain. Chem. Eng. 2017, 5, 4630-4636. [CrossRef]

211. Quynh, L.T.; Van, C.N.; Bitla, Y.; Chen, J.W.; Tzeng, W.Y.; Liao, S.C.; Tsai, K.A.; Chen, Y.C.; Wu, C.L.; Lai, C.H.; et al. Self-Assembled $\mathrm{BiFeO}_{3-\varepsilon}-\mathrm{Fe}_{2} \mathrm{O}_{3}$ vertical heteroepitaxy for visible light photoelectrochemistry. Adv. Energy Mater. 2016, 6, 1600686. [CrossRef]

212. Khoomortezaei, S.; Abdizadeh, H.; Golobostanfard, M.R. Triple layer heterojunction $\mathrm{WO}_{3} / \mathrm{BiVO}_{4} / \mathrm{BiFeO}_{3}$ porous photoanode for efficient photoelectrochemical water splitting. ACS Appl. Energy Mater. 2019, 2, 6428-6439. [CrossRef]

213. Li, S.; Jing, L.; Fu, W.; Yang, L.; Xin, B.; Fu, H. Photoinduced charge property of nanosized perovskite-type $\mathrm{LaFeO}_{3}$ and its relationships with photocatalytic activity under visible irradiation. Mater. Res. Bull. 2007, 42, 203-212. [CrossRef]

214. Celorrio, V.; Bradley, K.; Weber, O.J.; Hall, S.R.; Fermin, D.J. Photoelectrochemical properties of $\mathrm{LaFeO}_{3}$ nanoparticles. ChemElectroChem 2014, 1, 1667-1671. [CrossRef]

215. Martinelli, G.; Carotta, M.C.; Ferroni, M.; Sadaoka, Y.; Traversa, Y. Screen-printed perovskite-type thick films as gas sensors for environmental monitoring. Sens. Act. B Chem. 1999, 55, 99-110. [CrossRef]

216. Parida, K.M.; Reddy, K.H.; Martha, S.; Das, D.P.; Biswal, N. Fabrication of nanocrystalline $\mathrm{LaFeO}_{3}$ : An efficient sol-gel auto-combustion assisted visible light responsive photocatalyst for water decomposition. Int. J. Hydrogen Energy 2010, 35, 12161-12168. [CrossRef]

217. Sora, I.N.; Fontana, F.; Passalacqua, R.; Ampelli, C.; Perathoner, S.; Centi, G.; Parrino, F.; Palmisano, L. Photoelectrochemical properties of doped lanthanum orthoferrites. Electrochim. Acta 2013, 109, 710-715. [CrossRef]

218. Yu, Q.; Meng, X.; Wang, T.; Li, P.; Liu, L.; Chang, K.; Liu, G.; Ye, J. A highly durable p-LaFeO $3 / n-\mathrm{Fe}_{2} \mathrm{O}_{3}$ photocell for effective water splitting under visible light. Chem. Commun. 2015, 51, 3630-3633. [CrossRef]

219. May, K.J.; Fenning, D.P.; Ming, T.; Hong, W.T.; Lee, D.; Stoerzinger, K.A.; Biegalski, M.D.; Kolpak, A.M.; Horn, Y.S. Thickness-dependent photoelectrochemical water splitting on ultrathin $\mathrm{LaFeO}_{3}$ films grown on $\mathrm{Nb}: \mathrm{SrTiO}_{3}$. J. Phys. Chem. Lett. 2015, 6, 977-985. [CrossRef] 
220. Peng, Q.; Shan, B.; Wen, Y.; Chen, R. Enhanced charge transport of $\mathrm{LaFeO}_{3}$ via transition metal (Mn, $\mathrm{Co}, \mathrm{Cu})$ doping for visible light photoelectrochemical water oxidation. Int. J. Hydrogen Energy 2015, 40, 15423-15431. [CrossRef]

221. Ji, W.; Yao, K.; Lim, Y.F.; Liang, Y.C.; Suwardi, A. Epitaxial ferroelectric $\mathrm{BiFeO}_{3}$ thin films for unassisted photocatalytic water splitting. Appl. Phys. Lett. 2013, 103, 062901. [CrossRef]

222. Wu, X.; Li, H.; Wang, X.; Jiang, L.; Xi, J.; Du, G.; Ji, Z. Ferroelectric enhanced photoelectrochemical water splitting in $\mathrm{BiFeO}_{3} / \mathrm{TiO}_{2}$ composite photoanode. J. Alloys Compd. 2018, 783, 643-651. [CrossRef]

223. Wheeler, G.P.; Choi, K.S. Photoelectrochemical properties and stability of nanoporous p-type $\mathrm{LaFeO}_{3}$ photoelectrodes prepared by electrodeposition. ACS Energy Lett. 2017, 2, 2378-2382. [CrossRef]

224. Pawar, G.S.; Tahir, A.A. Unbiased spontaneous solar fuel production using stable $\mathrm{LaFeO}_{3}$ photoelectrode. Sci. Rep. 2018, 8, 3501. [CrossRef] [PubMed]

225. Nassar, I.M.; Wu, S.; Li, L.; Li, X. Facile preparation of n-type $\mathrm{LaFeO}_{3}$ perovskite film for efficient photoelectrochemical water splitting. ChemistrySelect 2018, 3, 968-972. [CrossRef]

226. Pawar, G.S.; Elikkottil, A.; Seetha, S.; Reddy, K.S.; Pesala, B.; Tahir, A.A.; Mallick, T.K. Enhanced photoactivity and hydrogen generation of $\mathrm{LaFeO}_{3}$ photocathode by plasmonic silver nanoparticle incorporation. ACS Appl. Energy Mater. 2018, 1, 3449-3456. [CrossRef]

227. Wang, P.; He, Y.; Mi, Y.; Zhu, J.; Zhang, F.; Liu, Y.; Yang, Y.; Chen, M.; Cao, D. Enhanced photoelectrochemical performance of $\mathrm{LaFeO}_{3}$ photocathode with Au buffer layer. RSC Adv. 2019, 9, 26780-26786. [CrossRef]

228. Yang, J.; Wang, D.; Han, X.; Li, C. Roles of cocatalysts in photocatalysis and photoelectrocatalysis. Acc. Chem. Res. 2013, 46, 1900-1909. [CrossRef]

229. Liu, Q.; Zhou, Y.; You, L.; Wang, J.; Shen, M.; Fang, L. Enhanced ferroelectric photoelectrochemical properties of polycrystalline $\mathrm{BiFeO}_{3}$ film by decorating with Ag nanoparticles. Appl. Phys. Lett. 2016, 108, 022902. [CrossRef]

230. Ren, Y.; Nan, F.; You, L.; Zhou, Y.; Wang, Y.; Wang, J.; Su, X.; Shen, M.; Fang, L. Enhanced photoelectrochemical performance in reduced graphene oxide $/ \mathrm{BiFeO}_{3}$ heterostructures. Small 2017, 13, 1603457. [CrossRef]

231. Herzog, H.; Golomb, D. Carbon capture and storage from fossil fuel use. Encycl. Energy. 2004, 1, 277-287. [CrossRef]

232. Lee, J.H.; Trimm, D.L. Catalytic combustion of methane. Fuel Process. Technol. 1995, 42, 339-359. [CrossRef]

233. Campagnoli, E.; Tavares, A.C.; Fabbrini, L.; Rossetti, I.; Dubitsky, Y.A.; Zaopo, A.; Forni, L. $\mathrm{La} 1-\mathrm{xA}^{\prime} x \mathrm{Co} 1-\mathrm{yFeyO} \pm \delta\left(\mathrm{A}^{\prime}=\mathrm{Ce}, \mathrm{Sr}\right)$ catalysts for the flameless combustion of methane. J. Mater. Sci. 2006, 41, 4713-4719. [CrossRef]

234. Chen, J.; Arandiyan, H.; Gao, X.; Li, J. Recent Advances in Catalysts for Methane Combustion. Catal. Surv. Asia 2015, 19, 140-171. [CrossRef]

235. Jin, J.; Li, C.; Tsang, C.W.; Xu, B.; Lian, C. Catalytic combustion of methane over Pt-Ce oxides under scarce oxygen condition. Ind. Eng. Chem. Res. 2016, 55, 2293-2301. [CrossRef]

236. Eriksson, S.; Wolf, M.; Scheider, A.; Mantzaras, J.; Raimondi, F.; Boutonnet, M.; Jaras, S. Fuel-rich catalytic combustion of methane in zero emissions power generation processes. Catal. Today. 2006, 117, 447-453. [CrossRef]

237. Ciuparu, D.; Lyubovsky, M.R.; Altman, E.; Pfefferle, L.D.; Datye, A. Catalytic combustion of methane over palladium-based catalysts. Catal. Rev. 2002, 44, 593-649. [CrossRef]

238. Cimino, S.; Colonna, S.; De Rossi, S.; Faticanti, M.; Lisi, L.; Pettiti, I.; Porta, P. Methane Combustion and $\mathrm{CO}$ oxidation on zirconia-supported $\mathrm{La}, \mathrm{Mn}$ oxides and $\mathrm{LaMnO}_{3}$ perovskite. J. Catal. 2002, 205, 309-317. [CrossRef]

239. Landi, G.; Barbato, P.S.; Di Sarli, V.; Di Benedetto, A. Multifuel Catalytic Combustion in the Presence of Carbon Dioxide over Fully and Partially Perovskite-Coated Monoliths. Ind. Eng. Chem. Res. 2017, 56, 4920-4928. [CrossRef]

240. Barbato, P.S.; Di Sarli, V.; Landi, G.; Di Benedetto, A. High pressure methane catalytic combustion over novel partially coated LaMnO3-based monoliths. Chem. Eng. J. 2015, 259, 381-390. [CrossRef]

241. Di Sarli, V.; Barbato, P.S.; Di Benedetto, A.; Landi, G. Start-up behavior of a LaMnO3 partially coated monolithic combustor at high pressure. Catal. Today 2015, 242, 200-210. [CrossRef]

242. Landi, G.; Di Benedetto, A.; Barbato, P.S.; Russo, G.; Di Sarli, V. Transient behavior of structured LaMnO3 catalyst during methane combustion at high pressure. Chem. Eng. Sci. 2014, 116, 350-358. [CrossRef]

243. Barbato, P.S.; Di Benedetto, A.; Di Sarli, V.; Landi, G.; Pirone, R. High-Pressure Methane Combustion over a Perovskyte Catalyst. Ind. Eng. Chem. Res. 2012, 51,7547-7558. [CrossRef] 
244. Nakamura, T.; Petzow, G.; Gauckler, L.J. Stability of the perovskite phase $\mathrm{LaBO}_{3}(\mathrm{~B}=\mathrm{V}, \mathrm{Cr}, \mathrm{Mn}, \mathrm{Fe}, \mathrm{Co}, \mathrm{Ni})$ in reducing atmosphere I. Experimental results. Mater. Res. Bull. 1979, 14, 649-659. [CrossRef]

245. Spinicci, R.; Tofanari, A.; Delmasto, A.; Mazza, D.; Ronchetti, S. Catalytic properties of stoichiometric and non-stoichiometric $\mathrm{LaFeO}_{3}$ perovskite for total oxidation of methane. Mater. Chem. Phys. 2002, 76, 20-25. [CrossRef]

246. Alifanti, M.; Florea, M.; Cortes-Corberan, V.; Endruschat, U.; Delmon, B.; Parvulescu, V.I. Effect of $\mathrm{LaCoO}_{3}$ perovskite deposition on ceria-based supports on total oxidation of VOC. Catal. Today. 2006, 112, 169-173. [CrossRef]

247. Popescu, I.; Urda, A.; Yuzhakova, T.; Marcu, I.C.; Kovacs, J.; Sandulescu, I. $\mathrm{BaTiO}_{3}$ and $\mathrm{PbTiO}_{3}$ perovskite as catalysts for methane combustion. Comptes Rendus Chim. 2009, 12, 1072-1078. [CrossRef]

248. Taguchi, H.; Nakade, K.; Yosinaga, M.; Kato, M.; Hirota, K. Methane oxidation on perovskite-type $\mathrm{Ca}\left(\mathrm{Mn}_{1-\mathrm{x}} \mathrm{Ti}_{\mathrm{x}}\right) \mathrm{O}_{3-\delta}$. J. Am. Ceram. Soc. 2008, 310, 2007-2009. [CrossRef]

249. Tofan, C.; Klvana, D.; Kichnerova, J. Decomposition of nitric oxide over perovskite oxide catalysts: Effect of $\mathrm{CO}_{2}, \mathrm{H}_{2} \mathrm{O}$ and $\mathrm{CH}_{4}$. Appl. Catal. B 2002, 36, 311-323. [CrossRef]

250. Najjar, H.; Lamonier, J.; Mentré, O.; Giraudon, J.; Baris, H. Combustion synthesis of $\operatorname{LaMn}_{1-x} \mathrm{Al}_{\mathrm{x}} \mathrm{O}_{3+\delta}$ $(0 \leq x \leq 1)$ : Tuning catalytic properties for methane deep oxidation. Catal. Sci. Technol. 2013, 3, 1002-1016. [CrossRef]

251. Miao, F.; Wang, F.; Mao, D.; Guo, X.; Yu, J.; Huang, H.; Lu, G. Effect of different reaction conditions on catalytic activity of $\mathrm{La}\left((\mathrm{Mn}, \mathrm{Fe}) \mathrm{O}_{3+\lambda}\right.$ catalyst for methane combustion. Mater. Res. Express. 2019, 6, 5001. [CrossRef]

252. Edokpayi, J.N.; Odiyo, J.O.; Durowoju, O.S. Impact of Wastewater on Surface Water Quality in Developing Countries: A Case Study of South Africa. In Water Quality; Hlanganani, T., Ed.; IntechOpen: London, UK, 2017. [CrossRef]

253. Oh, H.J.; Lee, J.H.; Kim, Y.J.; Suh, S.J.; Lee, J.H.; Chi, C.S. Synthesis of effective titania nanotubes for wastewater purification. Appl. Catal. B 2008, 84, 142-147. [CrossRef]

254. Manu, B.; Chaudhari, S. Anaerobic decolorisation of simulated textile wastewater containing azo dyes. Bioresour. Technol. 2002, 82, 225-231. [CrossRef]

255. Lai, C.W.; Juan, J.C.; Ko, W.B.; Bee Abd Hamid, S. An overview: Recent development of titanium oxide nanotubes as photocatalyst for dye degradation. Int. J. Photoenergy 2014, 2014, 1-14. [CrossRef]

256. Ali, I.; Gupta, V.K. Advances in water treatment by adsorption technology. Nat. Protoc. 2006, 1, 2661-2667. [CrossRef] [PubMed]

257. Aoudj, S.; Drouiche, N.; Hecini, M.; Ouslimane, T.; Palaouane, B. Coagulation as a post-treatment method for the defluoridation of photovoltaic cell manufacturing wastewater. Procedia Eng. 2012, 33, 111-120. [CrossRef]

258. Kim, T.H.; Park, C.; Shin, E.B.; Kim, S. Decolorization of disperse and reactive dyes by continuous electrocoagulation process. Desalination 2002, 150, 165-175. [CrossRef]

259. Apin, R.; Waite, T.D. Comparison of three advanced oxidation processes for degradation of textile dyes. Water Sci. Technol. 2000, 42, 345-354. [CrossRef]

260. Cham, K.; Seok, J.D.; Se, G.L.; Sung, J.L.; Ho, Y.K. Visible-light absorptivity of a zincoxysulfide $\left(\mathrm{ZnO}_{\mathrm{x}} \mathrm{S}_{1-\mathrm{x}}\right)$ composite semiconductor and its photocatalytic activities for degradation of organic pollutants under visible-light irradiation. Appl. Catal. A 2007, 330, 127-133. [CrossRef]

261. Yu, J.; Wang, Y.; Xiao, W. Enhanced photoelectrocatalytic performance of $\mathrm{SnO}_{2} / \mathrm{TiO}_{2}$ rutile composite films. J. Mater. Chem. A 2013, 1, 10727-10735. [CrossRef]

262. Vassilis, J.I.; Stavros, G.P. Chapter 4. Adsorption and Ion Exchange. In Adsorption, Ion Exchange and Catalysis, 1st ed.; Poulopoulos, S., Inglezakis, V., Eds.; Elsevier: London, UK, 2006; pp. 243-353.

263. Geçgel, Ü.; Özcan, G.; Gürpınar, G.Ç. Removal of methylene blue from aqueous solution by activated carbon prepared from Pea Shells (Pisum sativum). J. Chem. 2013, 1-9. [CrossRef]

264. Kuang, Y.; Zhang, X.; Zhou, S. Adsorption of methylene blue in water onto activated carbon by surfactant modification. Water 2020, 12, 587. [CrossRef]

265. Bhargavi, R.J.; Maheshwari, U.; Gupta, S. Synthesis and use of alumina nanoparticles as an adsorbent for the removal of $\mathrm{Zn}(\mathrm{II})$ and CBG dye from wastewater. Int. J. Ind. Chem. 2014, 6, 31-41. [CrossRef]

266. Ali, S.; Abbas, Y.; Zuhra, Z.; Butler, I.S. Synthesis of $\gamma$-alumina $\left(\mathrm{Al}_{2} \mathrm{O}_{3}\right)$ nanoparticles and their potential for use as an adsorbent in the removal of methylene blue dye from industrial wastewater. Nanoscale Advances. 2018, 1, 213-218. [CrossRef] 
267. Tahir, S.S.; Rauf, N. Removal of a cationic dye from aqueous solutions by adsorption onto bentonite clay. Chemosphere 2006, 63, 1842-1848. [CrossRef]

268. Hu, Q.H.; Qiao, S.Z.; Haghseresht, F.; Wilson, M.A.; Lu, G.Q. Adsorption study for removal of basic red dye using bentonite. Ind. Eng. Chem. Res. 2006, 45, 733-738. [CrossRef]

269. Wang, S.; Li, H.; Xu, L. Application of zeolite MCM-22 for basic dye removal from wastewater. J. Colloid Interface Sci. 2006, 295, 71-78. [CrossRef]

270. Barrera-Díaz, C.E.; Balderas-Hernández, P.; Bilyeu, B. Electrocoagulation: Fundamentals and prospectives. Electrochem. Water Wastew. Treatm. 2018, 4, 61-76. [CrossRef]

271. Bhandari, V.M.; Ranade, V.V. Advanced Physico-Chemical Methods of Treatment for Industrial. Ind. Wastew. Treatm. Recycl. Reuse Wastew. 2014, 81-140. [CrossRef]

272. Ghosh, D.; Solanki, H.; Purkait, M.K. Removal of Fe(II) from tap water by electrocoagulation technique. J. Hazard. Mater. 2008, 155, 135-143. [CrossRef]

273. Moussa, D.T.; El-Naas, M.H.; Nasser, M.; Al-Marri, M.J. A comprehensive review of electrocoagulation for water treatment: Potentials and challenges. J. Environ. Manag. 2017, 186, 24-41. [CrossRef] [PubMed]

274. Mustafa, M.G. Biochemical basis of ozone toxicity. Free Radical Biol. Med. 1990, 9, 245-265. [CrossRef]

275. Wilhelm, P.; Stephan, D. Photodegradation of rhodamine B in aqueous solution via $\mathrm{SiO}_{2} @ \mathrm{TiO}_{2}$ nano-spheres. J. Photochem. Photobiol. A 2007, 185, 19-25. [CrossRef]

276. Watanabe, T.; Takizawa, T.; Honda, K. Photocatalysis through excitation of adsorbates. 1. Highly efficient N-deethylation of rhodamine B adsorbed to cadmium sulfide. J. Phys. Chem. 1977, 81, 1845-1851. [CrossRef]

277. Takizawa, T.; Watanabe, K.; Honda, J. Photocatalysis through excitation of adsorbates. 2. A comparative study of Rhodamine B and methylene blue on cadmium sulfide. J. Phys. Chem. 1978, 82, 1391-1396. [CrossRef]

278. Qu, P.; Zhao, J.; Shen, T.; Hidaka, $\mathrm{H}_{\text {. }} \mathrm{TiO}_{2}$-assisted photodegradation of dyes: A study of two competitive primary processes in the degradation of $\mathrm{RB}$ in an aqueous $\mathrm{TiO}_{2}$ colloidal solution. J. Mol. Catal. A 1998, 129, 257-268. [CrossRef]

279. Haque, E.; Jun, J.W.; Jhung, S.H. Adsorptive removal of methyl orange and methylene blue from aqueous solution with a metal-organic framework material, iron terephthalate (MOF-235). J. Hazard. Mater. 2011, 185, 507-511. [CrossRef]

280. Li, Y.; Li, X.; Li, J.; Yin, J. Photocatalytic degradation of methyl orange by $\mathrm{TiO}_{2}$-coated activated carbon and kinetic study. Water Res. 2006, 40, 1119-1126. [CrossRef]

281. Qian, X.; Chen, Z.; Yang, X.; Zhao, W.; Liu, C.; Sun, T.; Zhou, D.; Yang, Q.; Wei, G.; Fan, M. Perovskite cesium lead bromide quantum dots: A new efficient photocatalyst for degrading antibiotic residues in organic system. J. Clean. Prod. 2019, 249, 119335. [CrossRef]

282. Chen, C.; Zhou, J.; Geng, J.; Bao, R.; Wang, Z.; Xia, J.; Li, H. Perovskite $\mathrm{LaNiO}_{3} / \mathrm{TiO}_{2}$ step-scheme heterojunction with enhanced photocatalytic activity. Appl. Surf. Sci. 2019, 503, 144287. [CrossRef]

283. Bresolin, B.M.; Hammouda, S.B.; Sillanpää, M. An emerging visible-light organic-inorganic hybrid perovskite for photocatalytic applications. Nanomaterials 2020, 10, 115. [CrossRef] [PubMed]

284. Elmorsi, T.M. Equilibrium isotherms and kinetic studies of removal of methylene blue dye by adsorption onto miswak leaves as a natural adsorbent. J. Environ. Prot. 2011, 2, 817-827. [CrossRef]

285. Shah, N.S.; Khan, J.A.; Sayed, M.; Khan, Z.U.H.; Iqbal, J.; Arshad, S.; Junaid, M.; Khan, H.M. Synergistic effects of $\mathrm{H}_{2} \mathrm{O}_{2}$ and $\mathrm{S}_{2} \mathrm{O}_{8}{ }^{2-}$ in the gamma radiation induced degradation of Congo-red dye: Kinetics and toxicities evaluation. Sep. Purif. Technol. 2019, 233, 115966. [CrossRef]

286. Chaibakhsh, N.; Ahmadi, N.; Zanjanchi, M.A. Optimization of photocatalytic degradation of neutral red dye using $\mathrm{TiO}_{2}$ nanocatalyst via Box-Behnken design. Desalinat. Water Treat. 2015, 57, 9296-9306. [CrossRef]

287. Wahab, H.S.; Hussain, A.A. Photocatalytic oxidation of phenol red onto nanocrystalline $\mathrm{TiO}_{2}$ particles. J. Nanostruct. Chem. 2016, 6, 261-274. [CrossRef]

288. Abdollahi, Y.; Abdullah, A.H.; Zainal, Z.; Yusof, N.A. Photocatalytic degradation of p-cresol by zinc oxide under UV Irradiation. Int. J. Mol.Sci. 2011, 13, 302-315. [CrossRef] [PubMed]

289. Li, P.; Liu, C.; Wu, G.; Heng, Y.; Lin, S.; Ren, A.; Lv, K.; Xiao, L.; Shi, W. Solvothermal synthesis and visible light-driven photocatalytic degradation for tetracycline of Fe-doped $\mathrm{SrTiO}_{3}$. RSC Adv. 2014, 4, 47615-47624. [CrossRef]

290. Karstens, T.; Kobs, K. Rhodamine B and rhodamine 101 as reference substances for fluorescence quantum yield measurements. J. Phys. Chem. 1980, 84, 1871-1872. [CrossRef] 
291. Szeto, W.; Kan, C.W.; Yuen, C.W.M.; Chan, S.W.; Lam, K.H. Effective photodegradation of methyl orange using fluidized bed reactor loaded with cross-linked chitosan embedded nano-CdS photocatalyst. Int. J. Chem. Eng. 2014, 2014, 1-16. [CrossRef]

292. Paşka, O.; Ianoş, R.; Păcurariu, C.; Brădeanu, A. Magnetic nanopowder as effective adsorbent for the removal of Congo Red from aqueous solution. Water Sci. Technol. 2013, 69, 1234-1240. [CrossRef]

293. Alnuaimi, M.M.; Rauf, M.A.; Ashraf, S.S. Comparative decoloration study of Neutral Red by different oxidative processes. Dyes Pigments. 2007, 72, 367-371. [CrossRef]

294. Fiege, H. Cresols and Xylenols. In Ulmann's Encyclopedia of Industrial Chemistry; Wiley: Hoboken, NJ, USA, 2000. [CrossRef]

295. Cosentino, U.; Pitea, D.; Moro, G.; Saracino, G.A.A.; Caria, P.; Varì, R.M.; Colombo, L.; Forloni, G.; Tagliavini, F.; Salmona, M. The anti-fibrillogenic activity of tetracyclines on PrP 106-126: A 3D-QSAR study. J. Mol. Model. 2008, 14, 987-994. [CrossRef] [PubMed]

296. Primo, A.; Corma, A.; García, H. Titania supported gold nanoparticles as photocatalyst. Phys. Chem. Chem. Phys. 2011, 13, 886-910. [CrossRef] [PubMed]

297. Zhao, J.C.; Wu, T.X.; Wu, K.Q.; Oikawa, K.; Hidaka, H.; Serpone, N. Photoassisted degradation of dye pollutants (III) degradation of the cationic dye rhodamine B in aqueous anionic surfactant $/ \mathrm{TiO}_{2}$ dispersions under visible light irradiation: Evidence for the need of substrate adsorption on $\mathrm{TiO}_{2}$ particles. Environ. Sci. Technol. 1998, 32, 2394-2400. [CrossRef]

298. Kominami, H.; Kumamoto, H.; Kera, Y.; Ohtani, B. Immobilization of highly active titanium(IV) oxide particles-A novel strategy of preparation of transparent photocatalytic coatings. Appl. Catal. B 2001, 30, 329-335. [CrossRef]

299. Shankar, K.; Basham, J.I.; Allam, N.K.; Varghese, O.K.; Mor, G.K.; Feng, X.; Paulose, M.; Seabold, J.A.; Choi, K.S.; Grimes, C.A. Recent advances in the use of $\mathrm{TiO}_{2}$ nanotube and nanowire arrays for oxidative photoelectrochemistry. J. Phys. Chem. C 2009, 113, 6327-6359. [CrossRef]

300. Yan, G.; Zheng, L.; Xie, L.; Weng, X.; Ye, J. Nature of Ag-Bi-codoped $\mathrm{TiO}_{2}$ visible light photocatalyst. Rare Metals. 2011, 30, 259-266. [CrossRef]

301. Wei, X.; Xu, G.; Ren, Z.; Xu, C.; Weng, W.; Shen, G.; Han, G. Single-crystal-like mesoporous $\mathrm{SrTiO}_{3}$ spheres with enhanced photocatalytic performance. J. Am. Ceram. Soc. 2010, 93, 1297-1305. [CrossRef]

302. Da Silva, L.F.; Avansi, W.; Andrés, J.; Ribeiro, C.; Moreira, M.L.; Longo, E.; Mastelaro, V.R. Long-range and short-range structures of cube-like shape $\mathrm{SrTiO}_{3}$ powders: Microwave-assisted hydrothermal synthesis and photocatalytic activity. Phys. Chem. Chem. Phys. 2013, 15, 12386. [CrossRef]

303. Puangpetch, T.; Sreethawong, T.; Yoshikawa, S.; Chavadej, S. Synthesis and photocatalytic activity in methyl orange degradation of mesoporous-assembled $\mathrm{SrTiO}_{3}$ nanocrystals prepared by sol-gel method with the aid of structure-directing surfactant. J. Mol. Catal. A Chem. 2008, 287, 70-79. [CrossRef]

304. Xie, T.H.; Sun, X.; Lin, J. Enhanced photocatalytic degradation of RhB driven by visible light-induced MMCT of Ti(IV)-O-Fe(II) Formed in Fe-Doped $\mathrm{SrTiO}_{3}$. J. Phys. Chem. C 2008, 112, 9753-9759. [CrossRef]

305. Dong, B.; Li, Z.; Li, Z.; Xu, X.; Song, M.; Zheng, W.; Wang, C.; Al-Deyab, S.S.; El-Newehy, M. Highly efficient $\mathrm{LaCoO}_{3}$ nanofibers catalysts for photocatalytic degradation of Rhodamine B. J. Am. Ceram. Soc. 2010, 93, 3587-3590. [CrossRef]

306. Jung, W.Y.; Hong, S.S. Synthesis of $\mathrm{LaCoO}_{3}$ nanoparticles by microwave process and their photocatalytic activity under visible light irradiation. J. Ind. Eng. Chem. 2013, 19, 157-160. [CrossRef]

307. Gao, F.; Chen, X.Y.; Yin, K.B.; Dong, S.; Ren, Z.F.; Yuan, F.; Yu, T.; Zou, Z.; Liu, J.M. Visible-light photocatalytic properties of weak magnetic $\mathrm{BiFeO}_{3}$ nanoparticles. Adv. Mater. 2007, 19, 2889-2892. [CrossRef]

308. Mohan, S.; Subramanian, B.; Bhaumik, I.; Gupta, P.K.; Jaisankar, S.N. Nanostructured $\mathrm{Bi}_{(1-\mathrm{x})} \mathrm{Gd}_{(\mathrm{x})} \mathrm{FeO}_{3}-\mathrm{A}$ multiferroic photocatalyst on its sunlight driven photocatalytic activity. RSC Adv. 2014, 4, 16871-16878. [CrossRef]

309. Guo, R.; Fang, L.; Dong, W.; Zheng, F.; Shen, M. Enhanced photocatalytic activity and ferromagnetism in Gd doped $\mathrm{BiFeO}_{3}$ nanoparticles. J. Phys. Chem. C 2010, 114, 21390-21396. [CrossRef]

310. Feng, Y.N.; Wang, H.C.; Luo, Y.D.; Shen, Y.; Lin, Y.H. Ferromagnetic and photocatalytic behaviors observed in Ca-doped $\mathrm{BiFeO}_{3}$ nanofibres. J. Appl. Phys. 2013, 113, 146101. [CrossRef]

311. Zhang, Z.A.; Liu, H.Y.; Lin, Y.H.; Wei, Y.; Nan, C.W.; Deng, X.L. Influence of La doping on magnetic and optical properties of bismuth ferrite nanofibers. J. Nanomater. 2012, 2012, 1-5. [CrossRef] 
312. Ramezanalizadeh, $\mathrm{H}$.; Manteghi, F. Design and development of a novel $\mathrm{BiFeO}_{3} / \mathrm{CuWO}_{4}$ heterojunction with enhanced photocatalytic performance for the degradation of organic dyes. J. Photoch. Photobio. A 2017, 338, 60-71. [CrossRef]

313. Liu, Y.; Ding, S.; Xu, J.; Zhang, H.; Yang, S.; Duan, X.; Sun, H.; Wang, S. Preparation of a p-n heterojunction $\mathrm{BiFeO}_{3} @ \mathrm{TiO}_{2}$ photocatalyst with a core-shell structure for visible-light photocatalytic degradation. Chin. J. Catal. 2017, 38, 1052-1062. [CrossRef]

314. Deganello, F.; Tummino, M.L.; Calabrese, C.; Testa, M.L.; Avetta, P.; Fabbri, D.; Prevot, A.B.; Montoneri, E.; Magnacca, G. A new, sustainable $\mathrm{LaFeO}_{3}$ material prepared from biowaste-sourced soluble substances. New J. Chem. 2015, 39, 877-885. [CrossRef]

315. Li, L.; Wang, X.; Zhang, Y. Enhanced visible light-responsive photocatalytic activity of $\mathrm{LnFeO}_{3}(\mathrm{Ln}=\mathrm{La}, \mathrm{Sm})$ nanoparticles by synergistic catalysis. Mater. Res. Bull. 2014, 50, 18-22. [CrossRef]

316. Thirumalairajan, S.; Girija, K.; Ganesh, I.; Mangalaraj, D.; Viswanathan, C.; Balamurugan, A.; Ponpandian, N. Controlled synthesis of perovskite $\mathrm{LaFeO}_{3}$ microsphere composed of nanoparticles via self-assembly process and their associated photocatalytic activity. Chem. Eng. J. 2012, 209, 420-428. [CrossRef]

317. Shen, H.; Xue, T.; Wang, Y.; Cao, G.; Lu, Y.; Fang, G. Photocatalytic property of perovskite $\mathrm{LaFeO}_{3}$ synthesized by sol-gel process and vacuum microwave calcination. Mater. Res. Bull. 2016, 84, 15-24. [CrossRef]

318. Thirumalairajan, S.; Girija, K.; Hebalkar, N.Y.; Mangalaraj, D.; Viswanathan, C.; Ponpandian, N. Shape evolution of perovskite $\mathrm{LaFeO}_{3}$ nanostructures: A systematic investigation of growth mechanism, properties and morphology dependent photocatalytic activities. RSC Adv. 2013, 3, 7549-7561. [CrossRef]

319. Wei, Z.X.; Wang, Y.; Liu, J.P.; Xiao, C.M.; Zeng, W.W. Synthesis, magnetization and photocatalytic activity of $\mathrm{LaFeO}_{3}$ and $\mathrm{LaFe}_{0.5} \mathrm{Mn}_{0.5-\mathrm{x}} \mathrm{O}_{3-\delta}$. Mater. Chem. Phys. 2012, 136, 755-761. [CrossRef]

320. Liang, Q.; Jin, J.; Liu, C.; Xu, S.; Li, Z. Constructing a novel p-n heterojunction photocatalyst $\mathrm{LaFeO}_{3} / \mathrm{g}-\mathrm{C}_{3} \mathrm{~N}_{4}$ with enhanced visible-light-driven photocatalytic activity. J. Alloys Compd. 2017, 709, 542-548. [CrossRef]

321. Ye, Y.; Yang, H.; Wang, X.; Feng, W. Photocatalytic, Fenton and photo-Fenton degradation of RhB over Z-scheme g- $\mathrm{C}_{3} \mathrm{~N}_{4} / \mathrm{LaFeO}_{3}$ heterojunction photocatalysts. Mat. Sci. Semicon. Proc. 2018, 82, 14-24. [CrossRef]

322. Wu, Y.; Wang, H.; Tu, W.; Liu, Y.; Tan, Y.Z.; Yuan, X.; Chew, J.W. Quasi-polymeric construction of stable perovskite-type $\mathrm{LaFeO}_{3} / \mathrm{g}-\mathrm{C}_{3} \mathrm{~N}_{4}$ heterostructured photocatalyst for improved Z-scheme photocatalytic activity via solid p-n heterojunction interfacial effect. J. Hazard. Mater. 2018, 347, 412-422. [CrossRef]

323. Zou, F.; Jiang, Z.; Qin, X.; Zhao, Y.; Jiang, L.; Zhi, J.; Xiao, T.; Edwards, P.P. Template-free synthesis of mesoporous $\mathrm{N}$-doped $\mathrm{SrTiO}_{3}$ perovskite with high visible-light-driven photocatalytic activity. Chem. Commun. 2012, 48, 8514-8516. [CrossRef]

324. Jiang, L.; Qui, Y.; Yi, Z. Potassium niobate nanostructures: Controllable morphology, growth mechanism, and photocatalytic activity. J. Mater. Chem. A 2013, 1, 2878-2885. [CrossRef]

325. Li, G.; Yi, Z.; Bai, Y.; Zhang, W.; Zhang, H. Anisotropy in photocatalytic oxidization activity of $\mathrm{NaNbO}_{3}$ photocatalyst. Dalton Trans. 2012, 41, 10194-10198. [CrossRef] [PubMed]

326. Ding, J.; Lü, X.; Shu, H.; Xie, J.; Zhang, H. Microwave-assisted synthesis of perovskite $\operatorname{ReFeO}_{3}(\mathrm{Re}: \mathrm{La}, \mathrm{Sm}$, Eu, Gd) photocatalyst. Mat. Sci. Eng. B 2010, 171, 31-34. [CrossRef]

327. Cho, C.M.; Noh, J.H.; Cho, I.S.; An, J.S.; Hong, K.S.; Kim, J.Y. Low-temperature hydrothermal synthesis of pure $\mathrm{BiFeO}_{3}$ nanopowders using triethanolamine and their applications as visible-light photocatalysts. J. Am. Ceram. Soc. 2008, 91, 3753-3755. [CrossRef]

328. Huo, Y.; Miao, M.; Zhang, Y.; Zhu, J.; Li, H. Aerosol-spraying preparation of a mesoporous hollow spherical $\mathrm{BiFeO}_{3}$ visible photocatalyst with enhanced activity and durability. Chem. Commun. 2011, 47, 2089-2091. [CrossRef] [PubMed]

329. Hao, C.; Wen, F.; Xiang, J.; Hou, H.; Lv, W.; Lv, Y.; Hu, W.; Liu, Z. Photocatalytic performances of $\mathrm{BiFeO}_{3}$ particles with the average size in nanometer, submicrometer, and micrometer. Mater. Res. Bull. 2014, 50, 369-373. [CrossRef]

330. Li, S.; Zhao, Y.; Wang, C.; Li, D.; Gao, K. Fabrication and characterization unique ribbon-like porous $\mathrm{Ag} / \mathrm{LaFeO}_{3}$ nanobelts photocatalyst via electrospinning. Mater. Lett. 2016, 170, 122-125. [CrossRef]

331. Fu, S.; Niu, H.; Tao, Z.; Song, J.; Mao, C.; Zhang, S.; Chen, C.; Wang, D. Low temperature synthesis and photocatalytic property of perovskite-type $\mathrm{LaCoO}_{3}$ hollow spheres. J. Alloys Compd. 2013, 576, 5-12. [CrossRef]

332. Yan, L.; Zhang, T.; Lei, W.; Xu, Q.; Zhou, X.; Xu, P.; Wang, Y.; Liu, G. Catalytic activity of gold nanoparti ${ }_{\mathrm{c}}$ les supported on $\mathrm{KNbO}_{3}$ microcubes. Catal. Today. 2014, 224, 140-146. [CrossRef] 
333. Dhanalakshmi, R.; Muneeswaran, M.; Shalini, K.; Giridharan, N.V. Enhanced photocatalytic activity of La-substituted $\mathrm{BiFeO}_{3}$ nanostructures on the degradation of phenol red. Mater. Lett. 2016, 165, 205-209. [CrossRef]

334. Hou, L.; Sun, G.; Liu, K.; Li, Y.; Gao, F. Preparation, characterization and investigation of catalytic activity of Li-doped $\mathrm{LaFeO}_{3}$ nanoparticles. J. Sol Gel Sci. Techn. 2006, 40, 9-14. [CrossRef]

335. Li, S.; Lin, Y.H.; Zhang, B.P.; Wang, Y.; Nan, C.W. Controlled fabrication of $\mathrm{BiFeO}_{3}$ uniform microcrystals and their magnetic and photocatalytic behaviors. J. Phys. Chem. C 2010, 114, 2903-2908. [CrossRef]

336. Xu, X.; Lin, Y.H.; Li, P.; Shu, L.; Nan, C.W. Synthesis and photocatalytic behaviors of high surface $\operatorname{area~}_{\mathrm{BiFeO}}$ thin films. J. Am. Ceram. Soc. 2011, 94, 2296-2299. [CrossRef]

337. Feng, Y.N.; Wang, H.C.; Shen, Y.; Lin, Y.H.; Nan, C.W. Magnetic and photocatalytic behaviors of Ba-doped $\mathrm{BiFeO}_{3}$ nanofibers. Int. J. Appl. Ceram. Technol. 2013, 11, 676-680. [CrossRef]

338. Wang, H.C.; Lin, Y.H.; Feng, Y.N.; Shen, Y. Photocatalytic behaviors observed in Ba and Mn doped $\mathrm{BiFeO}_{3}$ nanofibers. J. Electroceram. 2013, 31, 271-274. [CrossRef]

Publisher's Note: MDPI stays neutral with regard to jurisdictional claims in published maps and institutional affiliations.

(C) 2020 by the authors. Licensee MDPI, Basel, Switzerland. This article is an open access article distributed under the terms and conditions of the Creative Commons Attribution (CC BY) license (http://creativecommons.org/licenses/by/4.0/). 